\title{
Retelling the Story of Affirmative Action: Reflections on a Decade of Federal Jurisprudence in the Public Workplace
}

\author{
John Cocchi Day
}

\section{TABLE OF CONTENTS}

Introduction 61

I. The Dominant Narrative of Affirmative Action .......................................69

A. Narrative as a Source of Societal Meaning ..................................69

B. Enacting the Dominant Affirmative Action Narrative....................71

1. The Liberal Invocation of the Dominant Narrative ..................71

2. The Conservative Invocation of the Dominant Narrative........74

C. Critically Observing the Dominant Narrative ................................78

1. Liberals versus Conservatives in the Larger Societal

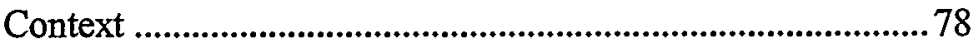

2. Reconsidering the Dominant Narrative .....................................8 80

II. The Constitutionality of Affirmative Action: Remedial Need as a

Compelling State Interest ....................................................................... 81

A. Setting the Stage: Supreme Court Pronouncements im

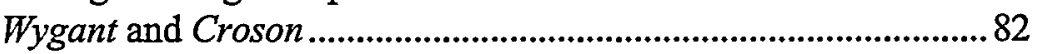

1. Wygant v. Jackson Board of Education ......................................8 82

2. City of Richmond v. J.A. Croson Co........................................85

B. Defining Remedial Interests as "Compelling" in the Lower

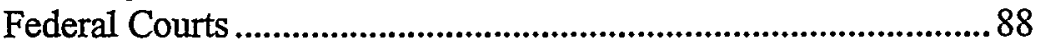

Copyright $(2001$ California Law Review, Inc. California Law Review, Inc. (CLR) is a California nonprofit corporation. CLR and the authors are solely responsible for the content of their publications.

$\dagger$ J.D. Candidate, School of Law, University of California, Berkeley (Boalt Hall), 2001; Ph.D. (Rhetoric), University of Southern California, 1998; B.A., University of Southern California, 1995. First, I am very grateful to Professor Robert Post; his guidance and intellectual rigor have been instrumental to the completion of this project. I am also very grateful to Professors Erwin Chemerinsky, Tom Hollihan, Linda Krieger, Randy Lake, Paul Mishkin, and David Oppenheimer, and to Julia Fromholz, Paul Derby, and Roger Stetson, for generously commenting on earlier drafts of this piece. Finally, I thank the editors of the California Law Review, particularly Ben Beltramo and James Oleson, for improving this Comment in innumerable ways. I dedicate this Comment to my mother, whose strength inspires me, and to my father, with whom I have regularly debated the topic of racial equity and to whom I am mdebted for sharpening my understanding of these issues. 
1. How Much Discrimination is Sufficient to Justify

Affirmative Action? 88

a. The Standard of Review: Defining a "Strong Basis in Evidence" 90

b. The Mechanics of Presenting a "Strong Basis in Evidence" 91

2. Can Statistics Alone Evidence Remedial Need? .....................96

3. Which Population is "Relevant" When Measuring Statistical Disparity?

III. The Constitutionality of Affirmative Action: Narrow Tailoring....... 103

A. Setting the Stage: Supreme Court Pronouncements in Paradise and Croson 103

1. United States v. Paradise .....................................................104

2. City of Richmond v. J.A. Croson ...........................................107

B. Defining "Narrowly Tailored" in the Lower Federal Courts ...... 109

1. The Necessity of Relief and the Efficacy of Alternative Remedies 109

2. The Flexibility and Duration of Relief 111

3. The Relationship of the Numerical Goals to the Relevant Labor Market.

4. The Impact of Relief on the Rights of Third Parties.............. 119

IV. Revisiting the Dominant Narrative

Conclusion 126 


\title{
Retelling the Story of Affirmative Action: Reflections on a Decade of Federal Jurisprudence in the Public Workplace
}

\author{
John Cocchi Day
}

This Comment identifies a commonly invoked rhetorical trope, the federal judiciary's rejection of race-conscious decision making, running through contemporary discussions of affirmative action. Liberal and conservative commentators alike often assume that the application of strict scrutiny has been "fatal in fact" to federal affirmative action. This Comment, however, challenges the empirical validity of these pessimistic conclusions by surveying the federal affirmative action jurisprudence of public employment from 1989 to the present. This survey examines the constitutional challenges of forty-nine remedial workplace affirmative action plans. Of these forty-nine plans, over forty percent (twenty-one) withstood, or skirted the application of, strict scrutiny by the federal courts. The narrow goal of this survey is to provide a more subtle and accurate account of the federal judiciary's public employment affirmative action jurisprudence. Accordingly, this Comment closely examines the past decade's jurisprudence, probing the demands placed upon affirmative action programs by the requirement that they be narrowly tailored to promote a compelling state interest. The critical goals of this project, however, extend further. By highlighting the space where carefully devised affirmative action plans may constitutionally inhabit, this Comment calls for a rethinking of the ways in which affirmative action is commonly discussed. As more and more commentators fallaciously describe the federal judiciary's "end of affirmative action," narrative structures both construct affirmative action as being constitutionally untenable and allow opponents of affirmative action to draw upon this unconstitutional ethos. By emphasizing how federal courts have validated many affirmative action plans even under the demanding doctrinal rubric of strict scrutiny, this Comment suggests that defenders of the raceconscious project might garner support for affirmative action by reclaiming the persuasive ethos that comes with the federal judiciary's constitutional imprimatur. 


\section{INTRODUCTION}

Many are familiar with the prevailing story ${ }^{1}$ of affirmative action. ${ }^{2}$ After inconsistently grappling with the issue for over a decade, the Supreme Court finally declared in 1989 that all racial classifications, benign or otherwise, demand the strictest judicial scrutiny. ${ }^{3}$ In so holding, the Court instructed lower federal courts to permit race-conscious affirmative action programs only when they were narrowly tailored to accomplish a compelling state interest. Because such scrutiny usually is "strict in theory and fatal in fact," turning point in the Court's race-based jurisprudence, ${ }^{5}$ a turning point that eventually would eschew race-conscious decision making for the colorblind ideal. ${ }^{6}$

1. For a thorough discussion of what I mean by the "prevailing story" of affirmative action, see Part I. For now, however, two points deserve mention. First, I will be using the terms "prevailing story" and "dominant narrative" throughout this piece to reference the common notion that race-conscious decision making is dying at the hands of the federal courts. Second, while this story is in fact pervasive, by no means do I think that it is the only story being told about affirmative action. I recognize that there is a great deal of legal scholarship that carefully avoids over-claiming affirmative action's judicial "demise." See infra note 11. I also understand that there are altogether different types of affirmative action narratives being told. See, e.g., Susan Sturm \& Lani Guinier, The Future of Affirmative Action: Reclaiming the Innovative Ideal, 84 CALIF. L. Rev. 953, 959-68 (1996) (discussing the "stock narratives" that run through the affirmative action debate, such as merit and fairness).

2. Let me acknowledge from the outset that the phrase "affirmative action" is a widely used and misunderstood term. For the purposes of this Comment, I use the phrase in much the same way that Professor Greenawalt does: "Affirmative action' is a phrase that refers to attempts to bring members of underrepresented groups, usually groups that have suffered discrimination, into a higher degree of participation in some beneficial program. Some affirmative action efforts include preferential treatment; others do not." KENT GreEnawalt, Discrimination and Reverse Discrimination 17 (1983). By embracing this broad definition, I purposely mean to include not only outright preferential policies, but also more "neutral" policies such as minority recruiting and edueation, modifications in hiring, promotion, and layoff procedures, and test-validation to minimize disparate impact. Randall Kennedy has usefully distinguished between "hard" and "soft" forms of affirmative action: "[S] forms [of affirmative action]... might include special recruitment efforts," while "hard" forms ... might include reserving a specific number of openings exclusively for members of the preferred group." Quoted in Andorra Bruno, Affirmative Action in Employment, in S.N. COLAMERY, Affirmative Action: Catalyst or Albatross? 59 (1998).

3. See City of Richraond v. J.A. Croson, 488 U.S. 469, $493-94$ (1989); sec also Adarand Constructors, Inc. v. Pena, 515 U.S. 200, 227 (1995).

4. Gerald Gunther, The Supreme Court, 1971 Term-Foreword: In Search of Evolving Doctrine on a Changing Court: A Model for a Newer Equal Protection, 86 HARv. L. REv. 1, 8 (1972).

5. E.g., Edward I. Koch, Editorial, Equal Opportunity-Without Minority Set-Asides, N.Y. TIMES, Feb. 20, 1989, at A19; Charles Krauthammer, Editorial, Exit Affirmative Action, WASH. Post, Feb. 3, 1989, at A25.

6. Generally speaking, the "colorblind ideaP" refers to a notion of equal protection that rejects any and all considerations of race, invidious or benign. For historical discussions of this "ideal" in the American legal context, see ANdrew Kull, The Color-Blind Construturion (1992); John C. Day, Rhetorieal Epochs in the Jurisprudence of Race (1998) (unpublished Ph.D. dissertation, University of Southem California) (on file with author). For a discussion of how this "ideal" has been turned toward markedly conservative ends, see Kimberlé Williams Crenshaw, Race, Reform, and Retrenchment: Transformation and Legitimation in Antidiscrimination Law, 101 HARV. L. REV. 1331 (1988). 
Nearly a decade later, highly visible events both inside the courtroom and out seemingly have confirmed this prediction. In Hopwood v. Texas, ${ }^{7}$ the Fifth Circuit found the non-remedial interest of diversity insufficient to justify affirmative action within law school admissions. In Taxman $v$. Board of Education of Piscataway, ${ }^{8}$ the Third Circuit extended Hopwood's logic into the statutory context, finding non-remedial interests wanting as justifications for affirmative action under Title VII. Outside the courtroom, the California Civil Rights Initiative (Proposition 209) amended the state constitution to prohibit all race-conscious decision making in state contracting, education, and employment. ${ }^{9}$ To many commentators, events such as these signal the end of race-conscious preferential policies. ${ }^{10}$ Although normative appraisals of these developments sharply diverge, this is largely how legal scholarship and the popular press tell the story of affirmative action. ${ }^{11}$

While there are elements of truth to this particular characterization of affirmative action, commentators who rely on this narrative too often present a grossly distorted vision of affirmative action both in the federal courts and the public domain. Running through the Supreme Court's affirmative action doctrine is an effort "to establish a fragile balance" between a recognition of group mequity on the one hand, and at least "a patent symbolic commitment to the values of individualism" on the other. ${ }^{12}$ While the Court tacitly recognizes that group-targeted remedies are necessary to disinantle America's apartheid, ${ }^{13}$ so too is there deep apprehension on the Court about the possibility of "slid[ing] into a regime of racial and ethnic rights and entitlements." 14 This tension between individual entitlement and group

7. 78 F.3d 932 (5th Cir. 1996), cert. denied, 578 U.S. 1033 (1996).

8. 91 F.3d 1547 (3rd Cir. 1996).

9. CAL. Const. art. I, § 31(a) (Supp. 2000).

10. See infra Part I.B.

11. See id. While many commentators participate in the dominant narrative, this is not to say that all commentary does so. For notable exceptions, see Janice R. Franke, Defining the Parameters of Permissible State and Local Affirmative Action Programs, 24 Golden Gate U. L. REv. 387 (1994); George R. La Noue, The Impact of Croson on Equal Protection Law and Policy, 61 Alb. L. Rev. 1 (1997); Maj. David A. Wallace \& Maj. Steven L. Schooner, Affirmative Action in Procurement: A Preview of the Post-Adarand Regulations in the Context of an Uncertain Judicial Landscape, 1997 ARMY LAw. 3; Leland Ware, Turning Back the Clock: The Assault on Affirmative Action, 54 WASH. U. J. UrB. \& ConTEMP. L. 3 (1998); Steven K. DiLiberto, Comment, Setting Aside Set Asides: The New Standard for Affirmative Action Programs in the Construction Industry, 42 VILL. L. REv. 2039 (1997).

12. Robert Post, Introduction: After Bakke, in RACE and REPRESENTATION: AfFirmative Action 13, 16-17 (Robert Post \& Michael Rogin eds., 1998).

13. I borrow this phrase from Douglass S. Massey \& Nancy A. Denton, American ApARTHEID (1993). In this perceptive book, Massey and Denton trace the historical roots and contemporary causes of America's continuing racial subjugation. I argue that the federal judiciary is not as oblivious to this racial reality as some commentators might have us believe. $C f$. TINSLEY $\mathrm{E}$. YARBRough, THE REHNQUIST CouRT AND THE ConstrTution 257 (2000) (arguing that the Court's affirmative action decisions, particularly Croson, reveal a Court that believes "racial and related forms of discrimination [are] largely confined to the past").

14. Post, supra note 12 , at 17. 
inequity is discernible in public attitudes as well. While polls reveal overwhelming opposition to racial quotas, pollsters report substantial popular support for more flexible race-conscious affirmative action plans that target identified episodes of discrimination. ${ }^{15}$ Professor Laura Stoker, for example, reveals that whites are much more likely to support affirmative action plans that are designed in the very terms demanded by the federal judiciary, that is, when affirmative action is narrowly tailored to reinedy particular discrimination. ${ }^{16}$ Commentators who blithely assert affirmative action's popular and judicial disfavor, however, invariably obscure these facts.

A full appreciation of this disjoint between the rhetoric of commentators and the reality of affirmative action depends in part upon a inore systematic review of federal case law. This Comment traces the path of affirmative action traversed by lower fcderal courts from 1989 to the present, focusing on the public einployment context ${ }^{17}$

15. Almost without exception, support for affirmative action rises when the use of quotas is expressly excluded. When people are asked for their general reaction to race-conscious employment affirmative action, they are uniformly negative: a 1991 NBC News/Wall Street Journal Poll reported $78 \%$ opposition to "hirmg preferences"; a 1994 ICR Survey Research Group poll reported $80 \%$ opposition to "preference in hiring"; a 1991 Gallop Poll reported 81\% opposition to "preferential treatment in getting jobs and places in college." Reprinted in Bruno, supra note 2, at 82-83. When the polling questions expressly exclude the use of "quotas," support rises markedly: a July 199I Harris Survey reported $46 \%$ support for "racial preference for minorities in employment and education, provided there are no rigid quotas" and reported $70 \%$ support for "federal laws requiring affirmative action programs ... in employment and in education, provided there arc no rigid quotas"; a 1991 NBC News/Wall Street Journal Poll reported 61\% support for affirmative action programs "to counteract the effects of discrimination . . . as long as there are no rigid quotas." Id. at 81-83.

16. Laura Stoker, Whites Resistance to Affirmative Action, in Perception ANd PreJudice 142 (Jon Hurwitz \& Mark Peffiey eds., 1998) ("When it comes to affirmative action programs . . . that are implemented as a 'narrowly tailored' remedial response to discriminatory hiring practices, it is not the case that 'mass opinion remains invariably opposed to preferential treatment'.... The portrait of opinion, instead, is of a public that is sharply divided.") (citation omitted).

17. I focus on public employment for two reasons. First, while there have been relatively comprehensive reviews of post-Croson affirmative action doctrine in the education and contracting contexts, see infra note 11 , I know of no other effort to comprehensively survey federal doctrine in the public employment context. Second, the need to highlight ongoing employment discrimination, and the important remedy of workplace affirmative action, has grown particularly acute. According to David B. Oppenheimer, "[e]mployment discrimination against mdividual women and minority group members is pervasive":

A recent study that combined and re-examined the results of ... six controlled experiments determined that when a white job applicant was interviewed, he or she had a $46.9 \%$ likelihood of being offered the job; for a similarly qualified black applicant, the likelihood of a job offer was $11.3 \%$. In other words, the white applicant was over four times more likely to get the job than the equally qualified black applicant. In $16.7 \%$ of the cases where both applicants were offered the job, the white applicant was offered a higher starting salary, while the reverse never occurred.

David Benjamin Oppenheiner, Understanding Affirmative Action, 23 Hastings ConsT. L. Q. 92I, 969, 971 (1996). Despite this ongoing and systemic discrimination, "a majority (58\%) of white respondents ... believes that on the subject of jobs the average black American is as well off as the average white American, and $45 \%$ believe the same of Hisparic Americans." Id. at 972 . Given this 
exclusively. ${ }^{18}$ The narrow goal of this survey is to provide a more subtle and accurate account of the federal judiciary's public employment affirmative action jurisprudence. The critical goals of this project, however, extend further. By highlighting the space where carefully devised affirmative action plans may constitutionally inhabit, I call for a rethinking of the ways in which

affirmative action is commonly discussed. Public einployment affirmative action has greater constitutional vitality than traditional narratives suggest. But why is this fact so often ignored by commentators? Does the vitality of race-conscious decision making in the workplace call into question larger societal affirmative action narratives, or can workplace affirmative action be relevantly distinguished from affirmative action in, say, the contracting or educational contexts? While my survey of employment affirmative action does not purport to answer these questions definitively, I do hope that the framing of these questions will assist in the re-creation of more subtle narratives.

This Comment's effort to retell affirmative action's story begins with the recoguition that workplace affirmative action remains alive and well in the federal judiciary. I found ample evidence of this vitality by turning to the equal-protection challenges of these programs reported in federal decisions since $1989 .{ }^{19}$ I examined the constitutional challenges of forty-nine remedial workplace affirmative action plans, as they were reported in fiftythree federal decisions. Of these forty-nine plans, over forty percent (twenty-one) withstood, or skirted the application of, strict scrutiny by the federal courts. ${ }^{20}$ Four other circuit courts expressed a generally positive

persistent but yet unseen discrimination, I felt it necessary to highlight the importance and continued constitutional viability of workplace affirmative action.

18. While the text of this piece exclusively deals with public employment, I briefly survey federal affirmative action decisions in the public contracting context as well. See infra note 25 .

19. Methodologically, I only considered federal cases where the public employment affirmative action plan asserted a remedial interest, where an equal protection challenge was brought against this plan, and where the court reached the merits of this constitutional challenge. While appellate courts sometimes remand cases back to the district courts for further evidential findings, and thus technically do not "invalidate" the plan, I did not consider these plans when calculating the number of employment affirmative action plans that have withstood strict scrutiny over the past decade. I derived my numerical calculations by examining the percentage of plans that have, up until the publication of this Comment, actually survived federal strict scrutiny review. Thus, in situations where a single affirmative action plan is considered multiple times by different federal courts, I counted only the most recent judicial resolution of the plan.

20. Eighteen affirmative action plans were found to be permissible racial classifications. See Boston Police Superior Officers Fed'n v. City of Boston, 147 F.3d 13 (1st Cir. 1998); McNamara v. City of Chicago, 138 F.3d 1219 (7th Cir. 1998); Edwards v. City of Houston, 37 F.3d 1097 (5th Cir. 1994); Peightal v. Metro. Dade County (Peightal II), 26 F.3d 1545 (11th Cir. 1994); Officers for Justice v. Civil Serv. Comm'n, 979 F.2d 721 (9th Cir. 1992); Jansen v. City of Cimcinnati, 977 F.2d 238 (6th Cir. 1992); VogeI v. City of Cincinnati, 959 F.2d 594 (6th Cir. 1992); Donaghy v. City of Omaha, 933 F.2d 1448 (8th Cir. 1991); Peightal v. Metro. Dade County (Peightal I), 940 F.2d 1394 (11th Cir. 1991) (concerning the same plan as Peightal II); Davis v. City \& County of San Francisco, 890 F.2d 1438 (9th Cir. 1989); Howard v. McLucas, 871 F.2d 1000 (11th Cir. 1989); Chi. Fire Fighters Union Local 
attitude toward workplace affirmative action, but remanded the plan at issue to the district court for further evidentiary findings. ${ }^{21}$ Of those workplace affirmative action plans invalidated under equal protection, twelve lacked both a compelling remedial interest and proper tailoring. ${ }^{22}$ Of the remaining twelve plans, four were found to have insufficient evidence of a compelling remedial purpose, ${ }^{23}$ while eight were inadequately tailored. ${ }^{24}$ These raw numbers, numbers that roughly comport with the federal judiciary's treatment of affirmative action in other contexts, ${ }^{25}$ reveal that the

No. 2 v. City of Chicago, 1999 WL 1289125 (N.D. Ill. Dec. 30, 1999); Majeske v. City of Chicago, 29 F. Supp. 2 d 872 (N.D. Ill. 1998); Allen v. Ala. State Bd. of Educ., 976 F. Supp. 1410 (M.D. Ala. 1997), aff'd, 164 F.3d 1347 (11th Cir. 1999); Shuford v. Ala. State Bd. of Educ. (Shuford II), 897 F. Supp. 1535 (M.D. Ala. 1995); Sims v. Montgomery County Comm'n (Sims Il), 887 F. Supp. 1479 (M.D. Ala. 1995); Shuford v. Ala. State Bd. of Educ. (Shuford I), 846 F. Supp. 1511 (M.D. Ala. 1994); Sims v. Montgomery County Comm'n (Sims I), 873 F. Supp. 585 (M.D. Ala. 1994) (involving the same plan as Sims II); Paganucci v. City of New York, 785 F. Supp. 467 (S.D.N.Y. 1992), aff'd, 993 F.2d 310 (2d Cir. 1993); Houston Chapter of the Int'l Ass'n of Black Prof'l Firefighters v. City of Houston, 1991 WL 340296 (S.D. Tex. May 3, 1991). One plan was found to be a permissible racial classification, but nonetheless was rejected for extra-constitutional "fairness" considerations. See United States v. City of Hialeah, 899 F. Supp. 603 (S.D. Fla. 1994), aff'd, 140 F.3d 968 (11th Cir. 1998). And two plans were found to involve no racial classification at all, rendering the application of strict scrutiny unnecessary. See Hayden v. County of Nassau, 180 F.3d 42 (2nd Cir. 1999); Honadle v. Univ. of Vt. \& State Agric. Coll., 56 F. Supp. 2 d 419 (D. Vt. 1999).

21. See Erwin v. Daley, 92 F.3d 521 (7th Cir. 1996); Aiken v. City of Memphis, 37 F.3d 1155 (6th Cir. 1994); Ensley Branch, NAACP v. Seibels, 31 F.3d 1548 (11th Cir. 1994); United Black Firefighters Ass'n v. City of Akron, 976 F.2d 999 (6th Cir. 1992).

22. See Dallas Fire Fighters Ass'n v. City of Dallas, Texas, 150 F.3d 438 (5th Cir. 1998), cert. denied, 526 U.S. 1046 (1999); Dallas Fire Fighters Ass'n v. City of Dallas, Texas, 885 F. Supp. 915 (N.D. Tex. 1995) (both cases involved the same plan); Police Ass'n ex rel. Cannatella v. City of New Orleans, 100 F.3d 1159 (5th Cir. 1996); Police Ass'n v. City of New Orleans, 1995 WL 311982 (E.D. La. May 18, 1995) (both cases involved the same plan); Middleton v. City of Flint, Michigan, 92 F.3d 396 (6th Cir. 1996); Hayes v. N. State Law Enforcement Officers Ass'n, 10 F.3d 207 (4th Cir. 1993); Detroit Police Officers Ass'n v. Young, 989 F.2d 225, 228 (6th Cir. 1993); Long v. City of Saginaw, 911 F.2d 1192 (6th Cir. 1990); Freeman v. City of Fayetteville, 971 F. Supp. 971 (E.D.N.C. 1997); Kane v. Freeman, 1997 U.S. Dist. LEX1S 4063 (M.D. Fla. Mar. 17, 1997); N. State Law Enforcement Officers Ass'n v. Charlotte-Mecklenburg Police Dep't, 862 F. Supp. 1445 (W.D.N.C. 1994); Bertoncini v. City of Providence, 767 F. Supp. 1194 (D.R.1. 1991); Dozier v. Chupka, 763 F. Supp. 1430 (S.D. Ohio 1991); Krupa v. New Castle County, 732 F. Supp. 497 (D. Del. 1990).

23. See Md. Troopers Ass'n v. Evans, 993 F.2d 1072, 1076 (4th Cir. 1993); Lalla v. City of New Orleans, 1999 WL 138900 (E.D. La. Mar. 12, 1999); Killebrew v. City of Greenwood, 988 F. Supp. 1014 (N.D. Miss. 1997); In re Chi. Police Officer Promotions, 1994 WL 424146 (N.D. Ill. Aug. Il, 1994).

24. See Alexander v. Estepp, 95 F.3d 312 (4th Cir. 1996); In re Birmingham Reverse Discrimination Employment Litig., 20 F.3d 1525 (1 lth Cir. 1994); Crumpton v. Bridgeport Educ. Ass'n, 993 F.2d 1023 (2nd Cir. 1993); Cunico v. Pueblo Sch. Dist. No. 60, 917 F.2d 431 (10th Cir. 1990); Ashton v. City of Memphis, 49 F. Supp. 2d 1051 (W.D. Tenn. 1999); Hiller v. County of Suffolk, 977 F. Supp. 202 (E.D.N.Y. 1997); Koski v. Gainer, 1995 WL 599052 (N.D. Ill. Oct. 5, 1995); Black Fire Fighters Ass'n of Dallas v. City of Dallas, 805 F. Supp. 426 (N.D. Tex. 1992), affd, 19 F.3d 992 (5th Cir. 1994).

25. For example, another oft-litigated arena of federal affirmative action involves race-based "set-asides" for minority contractors. Such "set-asides" typieally require that a certain percentage of state infrastructure monies be dispersed to minority-owned contracting enterprises. I surveyed the equal protection challenges of twenty-four "set-aside" programs as reported in twenty-five federal decisions since 1989 , finding that $28 \%$ of these decisions upheld (at least part) of the race-conscious "set-aside" 
federal judiciary is more supportive of race-conscious remedial programs than the dominant narrative suggests. While some critics cynically have read decisions such as Croson and Adarand to signal the Court's belief that "racial and related forms of discrimination [are] largely confined to the past," ${ }^{26}$ lower court decision-making belies such trenchant conclusions. ${ }^{27}$

To place this jurisprudential picture into a larger societal context, this Comment proceeds in four parts. Part I sketches the dominant affirmative action narrative operative both in contemporary legal scholarship and the popular press. While the exact origin of this narrative is unclear, many commentators draw an enervated picture of race-conscious decision making that bears strikingly little resemblance to what has, in fact, emerged from the federal judiciary this past decade. Examination of this picture reveals two important narrative characteristics. First, commentators on both the right and left tend to embrace the same narrative structure; while I speculate on the motivations of these ideologically diverse commentators, the fact remains that a surprisingly stable narrative cuts across the political spectrum. Second, despite the varying contexts in which affirmative action is found (employment, contracting, education,

program. Seven courts have found that a race-conscious "set-aside" program did not violate equal protection. See Harrison \& Burrowes Bridge Constructors, Inc. v. Cuomo, 981 F.2d 50 (2nd Cir. 1992); Ellis v. Skinner, 961 F.2d 912 (10th Cir. 1992); Associated Gen. Contractors of Cal. v. Coalition for Econ. Equity, 950 F.2d 1401 (9th Cir. 1991); Tenn. Asphalt Co. v. Farris, 942 F.2d 969 (6th Cir. 1991); Rothe Dev. Corp. v. United States Dep't of Defense, 49 F. Supp. $2 d 937$ (W.D. Tex. 1999); Mich. Road Builders Ass'n v. Blanchard, 761 F. Supp. 1303 (W.D. Mich. 1991), aff'd, 979 F.2d 851 (6th Cir. 1992); Milwaukee County Pavers Ass'n v. Fiedier, 710 F. Supp. 1532 (W.D. Wis. 1989). Eighteen courts have found that a race-conscious "set-aside" program did violate equal protection. See Associated Gen. Contractors of Ohio, Inc. v. Drabik, 214 F.3d 730 (6th Cir. 2000); W.H. Scott Const. Co. v. City of Jackson, Miss., 199 F.3d 206 (5th Cir. 1999); Eng'g Contractors Ass'n of S. Fla. v. Metro. Dade County, 122 F.3d 895 (11th Cir. 1997); Contractors Ass'n of E. Penn. v. City of Philadelphia, 91 F.3d 586 (3d Cir. 1996); O'Donnell Const. Co. v. District of Columbia, 963 F.2d 420 (D.C. Cir. 1992); Coral Constr. Co. v. King County, 941 F.2d 910 (9th Cir. 1991); Milwaukee County Pavers Ass'n v. Fiedler, 922 F.2d 419 (7th Cir. 1991); Associated Util. Contractors of Md., Inc. v. Mayor \& City Council of Balt., 83 F. Supp. 2d 613 (D. Md. 2000); Ass'n for Faimess in Bus., Inc. v. New Jersey, 82 F. Supp. 2d 353 (D.N.J. 2000); Concrete Works of Colo. v. City \& County of Denver, 86 F. Supp. 2d 1042 (D. Colo. 2000); Webster v. Fulton County, 51 F. Supp. 2d 1354 (N.D. Ga. 1999); F. Buddie Contracting, Ltd. v. Cuyahoga Cmty. Coll. Dist., 31 F. Supp. 2 d 571 (N.D. Ohio 1998); In re Sherbrooke Sodding Co., 17 F. Supp. 2d 1026 (D. Minn. 1998); Philips \& Jordan, Inc. v. Watts, 13 F. Supp. 2d 1308 (N.D. Fla. 1998); Houston Contractors Ass'n v. Metro. Transit Auth., 993 F. Supp. 545 (S.D. Tex. 1997); Arrow Office Supply Co. v. City of Detroit, 826 F. Supp. 1072 (E.D. Mich. 1993); Concrete Gen., Inc. v. Wash. Suburban Sanitary Comm'n, 779 F. Supp. 370 (D. Md. 1991); Main Line Paving Co. v. Bd. of Educ., 725 F. Supp. 1349 (E.D. Pa. 1989).

26. YARBROUGH, supra note 13 , at 257.

27. While it is theoretically possible to reconcile Professor Yarbrough's criticism with the lower courts' post-Croson treatment of affirmative action, by arguing that lower courts have simply diverged from Supreme Court jurisprudence, I submit that the Court harbors no illusion that discrimination is a thing of the past. Instead, a close reading of the major affirmative action decisions reveals a Court that is genuinely endeavoring to balance the competing demands of group inequity and individual entitlement. See Post, supra note 12; infra Parts II.A \& III.A. While one may agree or disagree with the Court's particular formulation of this balance, it seems perfectly clear that the Court is meaningfully grappling with these difficult issues. 
gerrymandering, etc.), the dominant narrative tends to singularly cast raceconscious decision making into one "disfavored" category. While this tendency is not wholly untenable, given the Supreme Court's apphication of strict scrutiny to all racial classifications (benign or otherwise), ${ }^{28}$ I highlight the dominant narrative's generality to explain why I examine it as a whole, rather than only in reference to employment affirmative action. Juxtaposing the dominant narrative's generality with the vitality of public employment affirmative action should, I hope, build momentum for a more nuanced understanding of affirmative action.

Once the dominant narrative has been laid out, Part II and Part III lay the groundwork for retelling affirmative action's story by turning to the jurisprudence of Equal Protection. The Supreme Court declared in Adarand Constructors, Inc. v. Pena that "all racial classifications, imposed by whatever federal, state, or local governmental actor, must be analyzed by a reviewing court under strict scrutiny." ${ }^{29}$ This exacting standard requires the government to prove: (1) that there is a compelling state interest for the employment action, and (2) that the action is narrowly tailored to meet that interest. ${ }^{30}$ Given strict scrutiny's prominence in the Court's raceconscious jurisprudence, its two-pronged approach will organize these sections. Part II examines the primary compelling state interest asserted for affirmative action programs in the employment context: remedying past discrimination. More specifically, this Part will examine what federal courts mean when they require a "strong basis in evidence" of past discrimination to warrant an affirmative action remedy. This area of the law is by far the murkiest, and consequently, we find lower federal courts relatively conflicted.

Part III focuses on the second prong of strict scrutiny; that is, what mandates are placed on such programs by the requirement that they be narrowly tailored? This body of law consistently highlights four factors: (1) the program's necessity, (2) its flexibility and expected duration, (3) the relationship between the program's numerical goals and the evidenced statistical disparity, and (4) the burden imposed on nonminority employees. Careful examination of the interplay of these factors in the employinent context reveals that while federal courts have carved out constitutional space for aggressive affirmative action plans, these plans must be carefully devised, implemented, and monitored.

Finally, Part IV discusses how the jurisprudential understandings of public workplace affirmative action, as laid out in Parts II and III, inform a more sophisticated popular understanding of race-based remedies writ large. This section examines what is at stake in pronoting a more refined

28. Sources cited supra note 3.

29. 515 U.S. 200,227 (1995).

30. Erwin Chemerinsky, Constitutional Law 550 (1997). 
popular understanding of affirmative action and highlights exactly how a better understanding of public workplace affirmative action might call the broader dominant narrative into question.

I

\section{The Dominant Narrative of Affirmative Action}

In this Comment, I identify a commonly invoked rhetorical trope, ${ }^{31}$ the federal judiciary's rejection of race-conscious decision nnaking, running through contemporary discussions of affirmative action. While this narrative is but one discursive thread in society's larger affirmative action conversation, it has gained moinentum increasingly in legal scholarship, the popular press, and the political sphere. In this Part, I highlight two contemporary trends in the affirmative action conversation. First, I illustrate the narrative commonality that cuts across many liberal and conservative discussions about affirmative action, discussions that often presuppose the end of affirmative action in the federal judiciary. Second, I tie these liberal and conservative discussions to societal patterns of political organization and discourse, showing that the rhetorical microcosin of affirmative action mirrors larger political trends. I begin, however, by describing how narrative functions as a source of societal meaning; introducing this theoretical frame should better enable the dominant narrative's critical evaluation.

\section{A. Narrative as a Source of Societal Meaning}

Human understanding is shaped by communication, a process enabled by competing societal narratives. People coine to understand their surrounding environment by identifying themselves with certain descriptions of the world and distinguishing themselves from others. Kenneth Burke has described this epistemic process in the following way: "Men seek for vocabularies that will be faithful reflections of reality. To this end, they must develop vocabularies that are selections of reahty. And any selection of reality inust, in certain circumstances, function as a deflection of reahity."32 This Comment argues that commentators often elide affirmative action's remaining constitutional viability by focusing exclusively on the varied ways that federal courts have invalidated raceconscious decision making; by talking in terms of affirmative action's

31. I use the terminology of thetorical trope to highlight the synecdochic function of the domimant narrative. When commentators, for example, frame the Adarand decision as the end of racially-conscious minority contractor set asides, infra Part I.B, they incorrectly allow the part to stand for the whole. For a discussion of synecdoche, and how it functions in discourse, see KENNETH Burke, A Gramiar of Motives 503-17 (1969).

32. Burke, supra note 31, at 59. See also KenNeth Burke, Atritudes Toward History 248 (3d ed. 1984) ("A man cannot say everything at once. Thus, his stateinents are necessarily 'efficient'... they throw strong light upon something, and in the process cast other things into shadow."). 
demise, commentators selectively focus on particular segments of the federal judiciary, thus deflecting attention from places where affirmative action continues to play an ongoing role. As this story of affirmative action is told and retold, it increasingly becomes the frame of reference from which many in society come to understand the federal judiciary's treatment of affirmative action. ${ }^{33}$

These narrative effects are better understood by appreciating that societal narratives are neither stable nor fixed; rather, they stem from a discursively tumultuous social milieu where competing narratives battle to be heard.$^{34}$ Every day, individuals encounter a panoply of descriptions about the world; some seem intuitive, others strained. As we pick and choose among these societal narratives, we come to understand the world through these narrative lenses. Professor Walter Fisher makes this very point: "The world as we know it is a set of stories that must be chosen among in order for us to live life in a process of continual re-creation." 35 The lesson here is twofold: individuals have sufficient autonomy to select certain societal narratives over others; however, these choices are influenced by societal narratives of the past, and constitutive of narratives stretching into the future. The dommant narrative's popular salience is reinforced with every commentator's invocation of it. However, as critics we need not take the dominant narrative as we find it. We should interrogate the world it

33. Kenneth Burke usefully employs the notion of "terministic screens" to describe this effect. By casting the federal judiciary's treatment of affirmative action in radically pessimistic terms, participants in the dominant narrative turn to the federal jurisprudence of affirmative action already expecting federal judiciary hostility, selectively highlighting that evidence wbich "confirms" their pessimistic expectations. Burke explains:

Not only does the nature of our terms affect the nature of our observations, in the sense that the terms direct the attention to one field rather than to another. Also, many of the "observations" are but implications of the particular terminology in terms of which the observations are made. In brief, much that we take as observations about 'reality' may be but the spinning out of possibilities implicit in our particular choice of terms.

KenNeth Burke, Language As Symbolic Action 46 (1966). Of course this is not to deny that there is, in faet, much evidence of federal judicial hostility toward affirmative action; the fact that such evidence exists in part explains the dominant narrative's popular salience. Rather, by presupposing ambient judicial hostility, the dominant narrative obscures both affirmative action's jurisprudential complexity and its remaining constitutional viability.

34. For a particularly astute description of this turbulent process, see M.M. BAKHTIN, THE Dialogic Imagination 276 (Michael Holquist ed., Caryl Emerson \& Michael Holquist trans., 1981) ("The word, directed toward its object, enters a dialogically agitated and tension-filled environment .... The living utteranee ... cannot fail to brush up against thousands of living dialogic threads . . . it cannot fail to become an active participant in social dialogue.").

35. Walter R. Fisher, Human Communication As Narration 65 (1987). Professor James Boyd White makes a similar point when discussing the legal "culture of argument":

$[T]$ he process of law is at once creative and educative. Those who use this language are perpetually learning what can and cannot be said, what can and cannot be done with it, as they try-and fail or succeed - to reach new formulations of their positions. . . In this way we may come to see the law less as a bureaucracy or a set of rules than as a community of speakers of a certain kind; as a culture of argument, perpetually remade by its participants.

James Boyd WhIte, Heracles' Bow 35 (1985). 
describes, not merely occupy it. The first step in this direction is to ask whether the dominant narrative in fact paints an accurate picture of federal affirmative action jurisprudence. While this is the question I will ask in Parts II and III, I first will sketch the dominant narrative as I find it in legal commentary, the popular press, and the political sphere.

\section{B. Enacting the Dominant Affirmative Action Narrative}

This past decade has witnessed an avalanche of commentary on the topic of affirmative action. Much of this dialogue has assessed the prospective viability of affirmative action in light of the Supreme Court's apphication of strict scrutiny. While cominentators and activists on both sides of the political spectrum have participated in this prospective conversation, it is striking that many liberals and conservatives had einbraced the same story regarding the federal judiciary's treatment of affirmative action. ${ }^{36}$ Examining each group in turn will facilitate a more subtle understanding of this narrative and an appreciation of the larger societal forces at work.

\section{The Liberal Invocation of the Dominant Narrative}

When liberals invoke the dominant narrative, they do so most often in the form of overly pessimistic legal commentary. Initially, liberals often draw on the dominant narrative when generally assessing the state of federal affirmative action jurisprudence. Professor Carl Livingston, for example, argues that "[t]he Court's affirmative action jurisprudence has shifted dramatically to the conservative right since 1978 ... the direction of this move is towards the dismantling of affirmative action." ${ }^{37}$ Liberals also

36. For efficiency's sake, this Comment refers to supporters of race-based affirmative action as "liberals" and to opponents as "conservatives." I recognize that this terminology is imprecise and that no exact overlap exists between liberals and conservatives on the one hand and supporters and detractors of affirmative action on the other. See Kimberle Crenshaw, Playing Race Cards: Constructing a Pro-Active Defense of Affirmative Action, 16 NAT'L BLACK L.J. 196, 199 (1999) (observing a surprising amount of "ambivalence among our liberal allies about affirmative action"). Liberal "ambivalence" notwithstanding, however, the fact remains that the far majority of legal and popular affirmative action commentary can be dichotomized along the lines of liberal supporters and conservative opponents.

37. Carl L. Livingston, Affirmative Action on Trial: The Retraction of Affirmative Action and the Case for its Retention, 40 How. L.J. 145, 161 (1996). See also Micbelle Adams, The Last Wave of Affirmative Action, I998 Wis. L. REv. 1395, 1397 (arguing that "the Supreme Court has effectively dismantled preferential forms of affirmative action in recent years"); Gabriel J. Chin, Bakke to the Wall: The Crisis in Bakkean Diversity, 4 WM. \& MARY BILL RTs. J. 881, 882 (1996) (finding that "[a]ffirmative action is in full retreat" in the judicial and political spheres); Charles R. Lawrence III, Each Other's Harvest: Diversity's Deeper Meaning, 31 U.S.F. L. Rev. 757, 763 (1997) (observing that the "Supreme Court has severely limited the scope of affirmative action in the workplace by its decisions in City of Richmond v. Croson and Adarand v. Pena, and, although the Court did not grant certiorari in Hopwood, some are predicting the end of affirmative action in higher education"); George A. Rutherglen, After Affirmative Action: Conditions and Consequences of Ending Preferences in Employment, 1992 U. ILL. L. REV. 339, 340 (argning that "[a]n increasingly conservative Court is 
invoke the dominant narrative while advocating particular policy changes. Robert Westley describes the "judicial disapprobation" facing conteinporary affirmative action plans when arguing for black reparations: "Affirmative action for Black Americans as a form of remediation for perpetuation of past injustice is almost dead. Due to a string of Supreme Court decisions .... the future possibility of using affirmative action to redress the perpetuation of past wrongs against Blacks is now in serious doubt." ${ }^{.38}$ Richard Kahlenberg, in arguing for a turn toward classbased affirmative action, warns that "[w]hile the Supreme Court has been edging away from affirmative action for a number of years, its recent decision in Adarand may prove devastating." 39

The liberal's invocation of the dominant narrative is most prominent, though, im scholarship that examines particular judicial decisions. When describing the Ninth Circuit's validation of Proposition 209, Juliana Capata poimted to "[r]ecent judicial activity in the area of affirmative action [that] siguals a movement toward limiting, or perhaps even eliminating, preferential treatment in both the public and private arenas"; 40 when

likely to limit affirmative action to progressively narrower circumstances, and perhaps, to prohibit it entirely"); Brent E. Simmons, Reconsidering Strict Scrutiny of Affirmative Action, 2 Mich. J. RACE \& L. 51, 57 (1996) (arguing that "[u]nder the guise of strictly scrutinizing affirmative action programs, lower court judges are declaring with increasing frequency that only race-neutral means nuay be employed in renedying systemic discrimination"); Michael Selmi, The Facts of Affirmative Action, 85 VA. L. Rev. 697, 698 (1999) (reviewing William G. Bowen \& Derek BoK, The Shape of the RIVER (1998)) (lamenting that "just as the documentation that affirmative action works arrives, we find ourselves in the midst of an extensive dismantling of the affirmative action infrastructure, one that may foreshadow the end of affirmative action"); Corinne E. Anderson, Comment, $A$ Current Perspective: The Erosion of Affirmative Action in University Admissions, 32 AKRON L. REv. 181, 182 (1999) (arguing that because of recent court decisions and political developments, "the very future of affirmative action nray be threatened'); Jeremy Moeser, Comment, Rough Terrain Ahead: A New Course for Racial Preference Programs, 49 Mercer L. REv. 915, 943 (1998) (arguing that "[i]n the areas of contracting, public employment, university admissions, and even districting, the courts have established a rigid framework for responding to the interests of minorities" and that "rarely can a preference program withstand a court's [strict] scrutiny").

38. Robert Westley, Many Billions Gone: Is it Time to Reconsider the Case for Black Reparations?, 40 B.C. L. REv. 429, 429-30 (1998). The dominant narrative is also sometimes invoked during purely historical discussions of America's racist past. See, e.g., Paul Finkelman, Affirmative Action For the Master Class: The Creation of the Proslavery Constitution, 32 Akron L. Rev. 423, 423 (1999) ("In the last decade courts have chipped away at affirmative action, and in many ways made it unusable as a tool to redress past and present discrimination. Sometime in the early Twenty-First Century we are likely to see the end of affirmative action.").

39. Richard D. Kahlenberg, Class-Based Affirmative Action, 84 CALIF. L. REv. 1037, 1038 (1996).

40. Juliana Capata, California Proposition 209 Does Not Impose Unconstitutional Burdens: Coalition for Economic Equity v. Wilson, 39 B.C. L. REv. 476, 477 (1998). See also Benjamin A. Doherty, Comment, Creative Advocacy in Defense of Affirmative Action: A Comparative Institutional Analysis of Proposition 209, 1999 WIs. L. REv. 91, 91, 93 (arguing that "[r]ecent federal court cases have weakened the base on which affirmative action programs have stood" and that "[c]onsidering the attacks to which affirmative action programs have been subjected, it is reasonable to predict that affirmative action programs may soon be greatly diminished"); Vanessa G. Tanaka, Comment, People Who Care v. Rockford Board Of Education and the Spectrum of Race-Conscious 
describing the Hopwood decision, the Honorable A. Leon Higginbotham predicted that the Fifth Circuit's holding would have a "detrimental effect on minority enrollment not only in the states ... where it has jurisdiction, but also in almost every other public and many private higher education institutions throughout the country....[Hopwood] casts a pall over affirmative action policies and diversity programs throughout American society"; 41 and when describing the Supreme Court's Adarand decision, Christine Enemark suggests that it "may substantially change or even bring an end to affirmative action programs $\mathrm{i}$ the United States." ${ }^{.42}$

The liberal perception of acute federal hostility toward affirmative action also is discernible in the popular press. Writing for the San Diego Union-Tribune, Morton Kondracke interprets the Court's unwillingness to review the Nimth Circuit's Proposition 209 decision as evidence of the Court's willingness "to drive a stake through the heart of affirmative action"; 43 writing for the U.S. News and World Report, Lincoln Caplan (and others) predict that as a result of Hopwood, "affirmative action as we

Remedies, 1999 Wrs. L. Rev. 347, 349, 376 (observing the "general trend" that affirmative action programs "cannot survive strict scrutiny," and pointing to a single circuit court opinion "as one point along the spectrum of affirmative action ... [that] reveals an emerging trend: The eventual elimination of all race-conscious policies, remedial or not.").

41. Honorable A. Leon Higginbotham, Afterword: Open Letter to Arthur Liman, 17 YALE L. \& PoL'Y Rev. 593, 596 (1998). See also Erin E. Byrnes, Note, Unmasking White Privilege to Expose the Fallacy of White Innocence: Using a Theory of Moral Correlativity to Make the Case for Affirmative Action Programs in Education, 41 ARIz. L. Rev. 535, 537 (1999) (arguing that "[t]he Hopwood decision makes any future use of affirnative action programs in university admissions a dubious possibility"); Erin M. Hardtke, Note, Elimination of Race as a Factor in Law School Admissions: An Analysis of Hopwood v. Texas, 80 MaRQ. L. REv. 1135, 1159 (1997) (arguing that Hopwood "carries great persuasive value and could prove fatal to many affirnative action programs in higher education"); Voris E. Johnson, Comment, Making Words on a Page Become Everyday Life: A Strategy to Help Gay Men and Lesbians Achieve Full Equality Under South Africa's Constitution, 11 EMORY INT'L L. REv. 583, 614 (1997) ("[T] States, at least with regard to edueation, is dcad."); Victor V. Wright, Note, Hopwood v. Texas: The Fifth Circuit Engages in Suspect Compelling Interest Analysis in Striking Down an Affirmative Action Admissions Program, 34 Hous. L. REv. 871, 873, 903 (1997) (arguing that affirmative action plans in lower courts "have not had much success in meeting" the strict scrutiny test and that "considering the current trend to end all affirmative action programs nationwide, subsequent attacks on race-conscious admissions programs outside of the Fifth Circuit may use Hopwood as persuasive authority to extend the Hopwood ... nuling to other circuits.").

42. Christine E. Enemark, Adarand Constructors, Inc. v. Pena: Forcing the Federal Communications Commission into a New Constitutional Regime, 30 Colum. J.L. \& Soc. ProBs. 215, 216 (1997). See also Cedric Merlin Powell, Hopwood: Bakke II and Skeptical Scrutiny, 9 SETon HaLl CoNST. L.J. 811, 831 (1999) (arguing that "Adarand is a clarion call to lower federal courts to invalidate affirmative action programs because they are not colorblind"); Margaret A. Sewell, Note, Adarand Constructors, Inc. v. Pena: The Armageddon of Affirmative Action, 46 DEPAUL L. REv. 611, 648 (1997) ("The Adarand case is clearly the armageddon of affirmative action. The Suprene Court's application of strict scrutiny to federally enacted affirmative action programs has resulted in the death of affirmative action as we know it.").

43. Morton Kondracke, Affirmative Action's Time is Short, S.D. UNION-TRIB., Nov. 12, 1997, at B-12. See also Admission Policies Must be 'Narrowly Tailored' to Avoid Liability, ENROLlment MGMT. ReP., Nov. 1997. 
know it in higher education is, for better or worse, headed toward extinction"; 44 and writing for the Washington Post, Richard Kahlenberg laments that the Court's Adarand decision "has largely taken the federal government out of the preference business." 45 These articles represent but a small sample of liberal journalism that accepts the notion that the federal judiciary is eviscerating affirmative action. ${ }^{46}$

\section{The Conservative Invocation of the Dominant Narrative}

Substantial similarity exists between the liberal and conservative invocations of the dominant narrative. Like the liberals, conservatives draw upon the dominant narrative both in their legal scholarship ${ }^{47}$ and the popular press. ${ }^{48}$ Unlike the liberals, however, conservatives have brought

44. Lincoln Caplan, et al., Affirmative Action as We Know it Began to Die Before Prop. 209Because of a Federal Court Case in the South, U.S. News \& WorLd REP., Dec. 23, 1996, at 26. See also Editorial, Addressing Race Issues, Austin AmER.-StATESMan, Sept. 21, 1997, at H2 ("Hopwood has come to symbolize a broader social retreat from affirmative action programs designed to close the economic and education gaps between minorities and whites."); More Affirmative-Action Fights Ahead-Suits Against Calif. Cities, Schools Will be Key Test of Measure, Seattle Tnmes, Nov. 4, 1997, at A2 ("Many legal experts say the Supreme Court's decision last year to allow the Texas law school ruling to stand appeared to be a retreat from its landmark 1978 ruling in the Allan Bakke reverse-discrimination case."); Henry J. Reske, Law School Affirmative Action in Doubt, 82 A.B.A. J. 36,36 (1996) (arguing that the Hopwood ruling "could jeopardize affirmative action programs at universities across the country").

45. Richard D. Kahlenberg, Bob Dole's Colorblind Injustice; On Affirmative Action, He Caves to Big Business, WASH. Post, June 2, 1996, at C1.

46. See Robin M. Bennefield, Running for Cover; University Affirmative Action Policies, BLACK IssUes IN HIGHER EDU., Oct. 14, 1999, at 22 ("[I]n recent years, the once-strong voice of the U.S. Supreme Court has been drowned out by the rumblings of the right and a declaration from the conservative-leaning 5th Circuit in New Orleans that Bakke is dead. Some in the higher education community are going further to sound its death knell by suggesting the removal of race from its admissions policies.'); Janet Marshall, Governor Defends Stance on Plan; He says Affirmative Action Policies are being Rejected by Voters and Judges Throughout the Country, SARAsOTA HERALD-TRIB., Feb. 21, 2000, at $1 \mathrm{~B}$ ("In numbers that anount to a trend, courts are striking down affirmative action programs that use race and gender as factors in university admissions and govermment contracting.").

47. See, e.g., Robert D. Alt, Toward Equal Protection: A Review of Affirmative Action, 36 WASHBURN L.J. 179, 181 (1997) (arguing that happenings like Hopwood and the California Civil Rights Initiative "sigual a larger, national movement in the courts and in public opinion away from a system of preferential policies, which have dictated education and employment policy for three decades, and toward a re-invigorated understanding of equal protection"); Michael S. Greve, Hopwood and its Consequences, 17 PACE L. REv. 1, 3 (1996) (arguing that "[a] decade or so from now, Hopwood will be remembered as the beginning of the end of affirmative action in higher edueation"); Jennifer $\mathrm{C}$. Brooks, Note, The Demise of Affirmative Action and the Effect on Higher Education Admissions: $A$ Chilling Effect or Much Ado About Nothing?, 48 DRAKE L. REv. 567, 574 (2000) (arguing that "[i]n light of the Fifth Circuit's [Hopwood] holding, the precedential value of Bakke is questionable"); Shane H. Freedman, Cornment, Affirmative Action: An Idea Whose Time Has Gone, 27 Seton Hall L. Rev. 1579,1618 (1997) (arguing that "Hopwood signifies the beginning of the end for affirmative action programs in university admissions settings").

48. See, e.g., Rep. Charles T. Canady, America's Struggle For Racial Equality, J. AM. Citizenship PoL'y Rev., Jan.-Feb. 1998, at 42 ("In a series of cases, the Supreme Court and federal courts of appeal have made it clear that the system of preference is built on an exceedingly shaky foundation."); Bruce Fein, End in Sight for Racial Politics?, WASH. TIMES, June 14, 1995, at A20 
the dominant narrative resoundingly into the political sphere. Whenever actions are proposed in the public political splere to roll back affirmative action, the dominant narrative invariably is close by. Two illustrative examples are congressional attempts to end federally-sponsored affirmative action and California's recent passage of Proposition 209.

Ever since the Court's Adarand decision, there have been periodic attempts in Congress to eliminate various forms of federal affirmative action. In 1998, for example, the Senate debated ending the federal Disadvantaged Business Enterprise (DBE) program, a program establishing flexible set-asides of Department of Transportation contracting dollars for women and minorities. Senator McConnell defended his proposed elimination of the DBE program by arguing that "[w]e nnust follow the clear decisions of the Supreme Court... and the decisions of the courts of appeals .... . [a]11 of [wlioin] have struck down race-based programs in the past few years-all of them." ${ }^{.49}$ In support of his claim that "the Supreme Court's decision in Adarand 'makes it exceedingly difficult for any affirmative action program to pass constitutional muster,"'50 Senator McConnell appealed to federal case law that is "replete with courts striking down programs that mandate different rules and different treatunent for citizens of different races." Wh While he pointed to "a long list of cases im the last few years where courts have declared programs like the DBE Program to be unconstitutional,"52 nowhere did he mention cases upholding such programs. ${ }^{53}$ Senator McConnell concluded by declaring that "[i]t is difficult to envisage a race-based classification that is narrowly tailored." Rising in support of Senator McConnell was Senator DeWine. "[G]iven the constitutional guidelines that have been clearly established by the Supreine Court," Senator DeWine posed the minority set-aside issue as a "fundamental choice-we can stand aside and watch federal courts dismantle race-based set aside programs one-by-one, or we can exercise leadership" by dismantling the DBE program altogether. ${ }^{55}$

A proposal to eliminate funding to those colleges and universities with affirmative action admissions policies sparked further congressional

(arguing that the Court's Adarand decision "placed the penultimate nail into the coffin of the euphemistically styled affirmative action programs" and that now "[0]nly the blind cannot see the imminent death of affirmative action").

49. 144 Cong. REc. S1486 (daily ed. Mar. 6, 1998) (describing the holdings of the 3d, 4th, 5th, 6th, 7th, 9th, 11th, and D.C. Circuits).

50. 144 Cong. Rec. S8895 (daily ed. July 23, 1998) (quoting Sen. Byrd).

51. Id. at $\mathrm{S} 8896$.

52. Id.

53. For a discussion and list of cases that have upheld affirmative action in the contracting minority set-aside context, see the articles cited supra note 11 and the cases listed supra note 25 . For such cases in the employment context, see Parts II and III generally.

54. 144 CoNG. REC. S1487 (daily ed. Mar. 6, 1998) (quoting the lower federal district court in Adarand).

55. Id. at S1484. 
debate. Like in the previous DBE debate, the dominant narrative framed anti-affirmative action arguments. Representative McIntosh, for example, asserted: "Federal appellate courts, including the U.S. Supreine Court, have repeatedly struck down racial preference systems used by college admission offices as unconstitutional."56 Representative Cox argued that the "use of racial preferences, moreover, is today im America, and has been for years, unconstitutional. The Supreme Court, and the Federal courts of appeal have struck them down in virtually every context." 57 According to Cox, cases such as Hopwood and Taxman hold that "[d]istinctions by race are so evil ... so arbitrary, and so invidious, that a State bound to defend the equal protection of the laws must not invoke thein in any public sphere." "58

While it is clear froin the foregoing discussion that the dominant narrative informs congressional debate over affirmative action, this narrative's political influence extends well beyond the congressional floor. Analysis of the political rhetoric surrounding California's Proposition 209 reveals that activists have begun to invoke the federal judiciary's supposed abdication of affirmative action in an effort to propel California's success nationwide. The California Civil Rights Initiative went into effect in August 1997, after the Ninth Circuit endorsed its constitutionality and the Supreme Court denied review. ${ }^{59}$ Responding to the circuit court decision, Jennifer Nelson, the executive director of the American Civil Rights Institute (an organization that helped pass Proposition 209), declared: "The beauty of this decision is that it really shows that the courts are at every level striking these racial preferences down and showing that there is no place in government for decisions to be made on the basis of race."60 After the Supreme Court's denial of certiorari, Ms. Nelson commented further: "We feel very uplifted. It's very clear that the courts are not finding these [affirmative action] programs very acceptable." Similarly, Ward Connerly, the successful initiative's most public supporter and a member of the University of California's Board of Regents, called upon the executive branch to "bring itself mto compliance with the spirit

56. Id. at $\mathrm{H} 2912$.

57. Id. at $\mathrm{H} 2900$.

58. Id. (quoting Thurgood Marshall's Brown v. Board of Education Supreme Court oral argument).

59. See Coalition for Economic Equity v. Wilson, 122 F.3d 692 (9th Cir. 1997), cert. denied, 522 U.S. 963 (1997).

60. Nancy E. Roman, Calif. Bias Ban Survives Appeal; Only O'Connor Can Block Law Now, WASH. TmEs, Aug. 22, 1997, at A1 (quoting Jennifer Nelson).

61. Maria T. Padilla, Affirmative Action: As Preference Programs Take Hits, Will the Concept Completely Crumble?, ORLANDo Sentinel, Sept. 14, 1997, at G1 (quoting Jennifer Nelson). 
of Proposition 209 and with the growing body of case law being handed down by courts throughout the land."

All of these statements represent an interesting transition in the anti-affirmative action campaign's rhetorical strategy. Before the passage of Proposition 209, leaders of the moveinent largely defined their objective as being counter to federal jurisprudence; ${ }^{63}$ once the Ninth Circuit upheld California's initiative, and the Suprenne Court denied review, this strategy markedly changed. Not surprisingly, the moveinent endeavored to fit its recent success into the dominant narrative's preexisting symbolic framework in an effort to propel California's success nationwide. Representative David Jaye, for example, characterized the Court's refusal to review the Ninth Circuit as a "trennendous constitutional victory" where "[t]he U.S. Supreme Court has just removed the biggest obstacle to getting rid of affirmative action procedures at the University of Michigan .... This ineans that the case does not have enough constitutional merit." ${ }^{264}$ Similarly, Terry Pell (legal counsel for the conservative Center for Individual Rights) suggested that the Court's denial of certiorari "supports the fight against affirmative action" and "helps make clear that the argument against racial preferences is a mainstream view, not a fringe one." ${ }^{\text {"S5 }}$ While it is unclear whether any firm conclusions can be inferred from the Supreme Court's denial of certiorari, ${ }^{66}$ these statements reveal that a variety of pohtical actors have invoked the dominant narrative to bolster the anti-affirmative action campaign.

62. Pat Buchanan, Editorial, It's Time for National Anti-Preference Legislation, Aucusta CHRON., Apr. 24, 1997, at A5 (quoting Ward Connerly).

63. Consider, for example, the following statement made by Thomas Wood, one of the California Civil Rights Initiative's drafters:

[T] here are some federal court decisions that argue, preposterously, im our view, that one can interpret the federal Civil Rights Act of 1964 to allow or encourage discrimination against certain groups in the population, but none of the court decisions make it mandatory on the part of an employer to do so, except under very narrowly tailored circumstances. So basically what the people of the state of California will be doing if they adopt the California Civil Rights Initiative, is to say look, thank you to the activists, justices on the Supreine Court, for your invitation to discriminate against some of our citizens on the basis of race, sex or ethnicity, but you haven't told us that it's mandatory to do so, and, that being the case, we don't want that sort of thing goimg on in our state.

Both Sides With Jesse Jackson, Transcript \# 157, CNN, Dec. 31, 1994, available at LEXIS, News Library, Transcripts File.

64. Janet Adamy \& Jeffrey Kosseff, Court Refuses to Hear Prop 209; Michigan Lawsuit May Not Be Affected, Mich. DAILY VIA U-WIRE, Nov. 4, 1997, available at LEXIS, News Library, Arcnws File (quoting Rep. Jaye).

65. Id. (quoting Terry Pell).

66. In fact, the Supreme Court has expressly said that denials of certiorari carry no precedential weight. Maryland v. Balt. Radio Show, Inc., 338 U.S. 912, 919 (1950). 


\section{Critically Observing the Dominant Narrative}

\section{Liberals versus Conservatives in the Larger Societal Context}

There can be little doubt that vastly different motivations drive the at times similar liberal and conservative expositions of the dominant narrative. When liberals invoke the dominant narrative, they typically do so to highlight what they view to be an ill-advised anti-affirmative action tenor in the federal judiciary. ${ }^{67}$ Liberals inay exaggerate federal court hostility, but they presumably do so to highlight the gravity of the situation, to frame the federal judiciary as conservative and in the most dubious terms possible. The practical effect of this strategy, however, is that few commentators today reflect on the federal judiciary's persisting commitment to affirmative action; as liberals increasingly invoke the trope of affirmative action's "demise," there are fewer and fewer audible voiccs in societal conversations that remind us of affirmative action's continued constitutional viability.

Given the popular notion that affirmative action is dying in the hands of the federal judiciary, it should come as little surprise that conservatives have pressed the dominant narrative into the larger political sphere. Legal scholars have written at length about the ethos of authority possessed by the federal judiciary. Professor Reva Siegel, for example, has observed that "where we fight some of the major social conflicts of our time ... we must reckon with the authority of legal discourse, both as it is expressed in the judicial opinion and as it circulates in everyday conversation ..."68 We Americans take the rule of law quite seriously, and as such, federal judicial pronouncements possess particular persuasive force. ${ }^{69}$ As a purely pragmatic matter, then, it makes sense that conservative political actors draw upon the dominant narrative when opposing affirmative action.

This political reality illustrates broader sociological lessons about how the liberal and conservative camps have functioned in modern America. For some time now, critics have observed both the failure of liberals to present a politically salient social agenda and the success of conservatives in constructing a popularly attractive intellectual counterestablishment. Professor George Lakoff observes that "[1]iberals do not understand what unifies their own worldview and so are helpless to deal effectively with conservatism. Not only is there no unified liberal political structure, but there is no overall effective liberal rhetoric to counter the carefully

67. See supra notes $37-46$ and accompanying text.

68. Reva B. Siegel, In the Eyes of the Law: Reflections on the Authority of Legal Discourse, in LAw's STORIEs 231 (Peter Brooks \& Paul Gewirtz eds., 1996).

69. See PaUl W. KaHN, The Reign of Law 2, 5 (1997) (arguing that "the rule of law is ... the starting point from which we [Americans] approach the partieular problems that arise within the political order" and that it is largely the federal "courts [that] have achieved a unique role in expressing the rule of law"). 
constructed conservative rhetoric." ${ }^{270}$ Similarly, Professor Paul Starr reports that while "conservatives have built an intellectual counterestabhshment outside the academic world that includes foundations, think tanks, communications networks, and publications... [that] have trained and fielded a sinall army of intellectuals to contest liberal ideas and to foster consensus among conservatives, ... [t] here is no liberal counterpart to this effort." $" 71$

These societal observations are strikingly visible in the affirmative action context. From an organizational standpoint, conservative opponents to affirmative action have marshaled an impressive infrastructure dedicated to challenging the constitutionality of affirmative action programs. ${ }^{72}$ From an analytic standpoint, the liberal espousal of the dominant narrative has at best failed to generate popular uproar against the federal courts' restriction of affirmative action, and at worst has undermined the very constitutional ground still available to race-conscious decision making. Despite the continued willingness of federal courts to validate the constitutionality of affirmative action, stories of affirmative action's "demise" have constituted narrative structures in very particular ways. For one, the stronger the dominant narrative becomes, the more difficult it is to defend race-conscious affirmative action; as more and more people believe that the federal courts have given up on affirmative action, defenders of race-conscious pohicies are faced with the apparent choice of finding alternatives or withering on the constitutional vine. ${ }^{73}$ Additionally, the dommant narrative offers detractors of affirmative action an attractive rhetorical device: the ethos of unconstitutionality. Given the dominant narrative's increasing presence, it should come as little surprise that opponents of race-conscious decision making increasingly ground their arguments in supposedly "vindicated" constitutional principles.

70. George Lakoff, Metaphor, Morality, and Politics, Or, Why Conservatives Have Left Liberals In the Dust (1995), at http://www.wwed.org/issues/Lakoff.html (last visited Sept. 29, 2000).

71. Paul Star, Liberalism, Conservatism, and the Intellectuals (1995), at http://www.princeton. edu/ starr/libcon.html (last visited Sept. 29, 2000).

72. See, e.g., Mark Johnson, Conservative Legal Groups Stealing Liberals' Thunder; They Turn To Courts To Win Their Battles, New Orleans Times-Picayune, Jan. 9, 2000, at A3. Johnson suggested:

It is the stuff of 1960 s legend: a small band of activist lawyers brandishes lawsuits to shift government policy on civil rights and school equity. The setting, however, is the ' $90 \mathrm{~s}$ and the lawyers are trying to derail affirmative action rather than expand it.... A handful of conservative public interest law groups in recent years have adopted the strategy and tactics of their liberal opponents, successfilly using lawsuits to alter law and policy across the Id. country.

73. This, it seems to me, is what drives in part the embrace of class-based affirmative action by many liberal commentators. See, e.g., Kahlenberg, supra note 39. 


\section{Reconsidering the Dominant Narrative}

If one accepts the foregoing description of the dominant narrative, namely (1) that both liberals and conservatives regularly characterize federal constitutional law as being unabashedly hostile toward all forms of race-conscious decision making, and (2) that this descriptive tendency roughly mirrors larger societal battles between liberals and conservatives, the question becomes: Does the dominant narrative present an accurate picture of federal affirmative action law? The answer to this question, I submit, is no.

Despite the federal courts' application of strict scrutiny, and the outpouring of unduly pessimistic commentary, race-conscious affirmative action continues to occupy a constitutionally viable position in federal jurisprudence. The disjoint between rhetoric and reality is disturbing because, as we have just seen, the dominant narrative gains more and more acceptance each time it is mvoked by liberals and conservatives alike. It is of course undeniable that some segments of the federal judiciary are acutely hostile toward affirmative action, constitutionally mvalidating programs at the first sigu of race-conscious preferences. ${ }^{74}$ Such opposition is also discernible in some segments of society. One need only look to the statewide mitiatives recently passed in California, Washington, and Florida, and to others gaining support in Arizona, Colorado, and Oregon, to discern the growing anti-affirmative action sentiment building in parts of this nation. ${ }^{75}$ Focusing on these developments alone, however, distorts both the federal judiciary's treatinent of affirmative action and the public's sentiment on this issue. Affirmative action is a complex doctrinal area, an area that resists blanket descriptions. In Parts II and III, I will examine affirmative action in the federal workplace; I will show that despite the federal courts' application of strict scrutiny, workplace affirmative action remains constitutionally viable in the federal judiciary. I hope to problematize the dommant narrative's global characterization of affirmative action by juxtaposing the pessimistic rhetoric of many commentators with the vitality of affirmative action in the public entployment context.

74. See supra Parts II.B \& III.B.

75. See Louis Freedberg, GOP Embraces Connerly on Affirmative Action, S.F. CHRoN., Feb. 13, 1997, at A1; Frank J. Murray, Justices Refuse to Rule on Prop. 209; California Can Ban State's SetAsides, WASH. TmES, Nov. 4, 1997, at Al; but see infra notes 233-34 and accompanying text (suggesting that these statewide initiatives do not reveal the strong anti-affirmative action sentiment that is commonly posited). 
II

The Constitutionality of Affirmative Action: Remedial Need as a COMPELling State INTEREST

In order for race-conscious public employment affirmative action plans to pass constitutional muster, they must (1) possess a compelling state interest, and (2) be narrowly tailored to accomplisl that interest. ${ }^{76}$ This Comment's effort to retell the narrative of affirmative action begins where federal courts liave encountered the greatest imterpretive difficulty; that is, what interests are sufficiently "compelling" to justify explicitly race-conscious affirmative action programs in the employment context? The far majority of cases addressing this issue involve a purported remedial need, where the government employer stipulates present or past discrimination as justification for race-conscious hiring, firing, or promotion decisions. While employers liave asserted a broad range of interests to warrant affirmative action in the workplace, ${ }^{77}$ it is the remedial justification that primarily occupies federal court attention, and as sucl, it will be the focus of my inquiry.

Reviewing the past decade's federal case law on this issue reveals several jurisprudential fault lines: What sort of discriminatory violation is necessary to warrant remedial affirmative action? What type of evidence must be marshaled to prove such discrimination? What comparative

76. ChEMERINSKY, supra note 30.

77. In addition to remedial need, employers have asserted functional considerations and employee diversity as interests sufficiently "coinpelling" to justify affirmative action in the public workplace. Courts have treated these asserted functional interests quite differently. See Police Ass'n ex rel. Cannatella v. City of New Orleans, 100 F.3d 1159, 1168 (5th Cir. 1996) (rejecting the functional claim that "more African-American supervisors could better supervise African-American officers who in turn were needed to relate to the larger African-American population"; instead, "an affirmative action plan must be narrowly tailored to remedy past specific instances of discrimination"); Wittmer v. Peters, 87 F.3d 916 (7th Cir. 1996) (allowing the appointment of a black lieutenant to boot camp staff because of uncontested expert testimony that the camp would not succeed in its mission of pacification and reformation without more African-Americans on staff); Patrolmen's Benevolent Ass'n v. City of New York, 74 F. Supp. 2d 321, 329 (S.D.N.Y. 1999) (holding that "a police department's 'operational needs' can be a compelling state interest which might justify race-based decision making"); Kane v. Freennan, 1997 U.S. Dist. LEXIS 4063, at *14 (M.D. Fla. Mar. 17, 1997) (rejecting the functional argument that police department diversity is necessary for effective imvestigation); Police Ass'n v. City of New Orleans, 1995 WL 311982, at * 13 (E.D. La. May 18, 1995) (rejecting the argument that "black sergcants can better supervise black officers, who can better police a predominantly black community"). Courts have regularly rejected, however the asserted interest of employee diversity. See Messner v. Meno, 149 F.3d 1181 (5th Cir. 1998) (rejecting the diversity rationale per se as a compelling interest for a race-conscious promotion plan); Hayes v. N. State Law Enforcement Officers Ass'n, 10 F.3d 207 (4th Cir. 1993) (rejecting the diversity argument in context of police promotions because there was not enough evidence tying diversity to that interest's purported benefits); Hiller v. County of Suffolk, 977 F. Supp. 202, 206 (E.D.N.Y. 1997) (finding that "[a]chieving diversity is not a sufficiently compelling state interest" in the employment context). For an academic discussion regarding the advisability of non-remedial compelling state interests in the employment context, see Susan M. Maxwell, Note, Racial Classifications Under Strict Scrutiny: Policy Considerations and the Remedial-Plus Approach, 77 TEX. L. Rev. 259 (1998). 
population should be used to measure minority underrepresentation? These questions have posed the most difficult interpretive challenges to lower federal courts, and as such, they offer an instructive framework for organizing this Part. Before reaching these questions, however, I first will provide some context by reviewing the relevant Supreme Court doctrine.

\section{A. Setting the Stage: Supreme Court Pronouncements in Wygant and Croson}

The Supreme Court has long struggled over the issue of affirmative action. Throughout the 1980s the Court endeavored to devise consistent standards for evaluating benign racial classifications, an endeavor that proved fruitless for quite some time. ${ }^{78}$ Eventually, the Court settled upon strict scrutiny as the proper level of constitutional inquiry. Even this conclusion, however, lacks "judicial guidance concerning the legitimate scope and limitations of affirmative action beyond the very narrow confines of the particular factual settings in an individual case. In particular, members of the Court are sharply divided on what ought to count as a sufficient constitutional justification for affirmative action." The holdings in Wygant v. Jackson Board of Education ${ }^{80}$ and City of Richmond v. J.A. Croson ${ }^{81}$ reveal the Court's ambiguity regarding the scope and makeup of those interests "compelling" enough to warrant remedial affirmative action in the employment context.

\section{Wygant v. Jackson Board of Education}

In Wygant, the Court was confronted with a layoff provision within a collective bargaining agreement between the Jackson Board of Education and a teachers' union. The provision required that in the event of layoffs, "teachers with the most seniority... shall be retained, except that at no time will there be a greater percentage of minority personnel laid off than the current percentage of minority personnel employed at the time of the layoff." 82 When layoffs were imminent in 1974, it became clear that this provision would entail laying off some senior nonminority teachers while retaining less experienced minority teachers. Applymg strict scrutiny to

78. For a lucid discussion of the Court's decisions during this era, see Michel Rosenfeld, AfFirmative Acrion AND Justice 163-215 (1991).

79. Id. at 214. While Professor Rosenfeld is undoubtedly correct about the Court's lack of clear guidance, at least one commentator values this ambiguity. See Cass R. Sunstein, Public Deliberation, Affirmative Action, and the Supreme Court, 84 CALIF. L. Rev. 1179, 1179, 1185 (1996) (arguing that the Court's "narrow [affirmative action] rulings" perform a "valuable catalytic function" in that they "stimulate public processes and direct[ ] the citizenry toward open discussion of underlying questions of policy and principle," a function that "has been far preferable to ... validation or invalidation of most affirmative action programs pursuant to clear doctrinal categories").

80. 476 U.S. 267 (1986).

81. 488 U.S. 469 (1989).

82. Wygant, 476 U.S. at 270. 
this provision, Justice Powell's plurality opinion began by asserting the principle that "[s]ocietal discrimination, without more, is too amorphous a basis for imposing a racially classified remedy." employer like the Board must ensure that, before it embarks on an affirmative-action program, it has convincing evidence that remedial action is warranted. That is, it must have sufficient evidence to justify the conclusion that there has been prior discrimination." $\$ 4$ While Justice Powell ultimately was unconvinced that the Jackson Board of Education had such "a strong basis in evidence," 85 he came to this conclusion without much explanation; ${ }^{86}$ his opinion, therefore, is not terribly helpful for assessing exactly what "convincing evidence" entails.

Justice O'Connor's concurring opinion, on the other hand, does shed some important light on this matter. ${ }^{87}$ She began by reiterating that "societal discrimination" alone can never be sufficiently coinpelling; that being said, Justice O'Connor insisted "that a contemporaneous or antecedent finding of past discrimination by a court or other competent body is not a constitutional prerequisite to a public employer's voluntary agreeinent to an affirmative action plan." "Fearing that "a requirement that public einployers make findings that they have engaged in illegal discrimination before they engage in affirmative action programs would severely undermine public employers' incentive to meet volnntarily their civil rights obligations," Justice O'Connor declared that employers may act whenever there is "information which gives thein a sufficient basis for concluding that remedial action is necessary." While this somewhat begs the question of what constitutes a "sufficient basis," Justice O'Connor offered further instruction. First, she concluded tliat evidence of prior discrimination rising to the level of a prima facie Title VII pattern or practice claim $^{90}$ would provide "a strong enough basis in evidence" for remedial

83. Id. at 276.

84. Id. at 277.

85. Id.

86. To be fair, Justice Powell did not spend much time on this issue largely because he already was convinced that the Board's policy was not narrowly tailored, thus rendering his analysis on the first prong of strict scrutiny moot. Id. at 278.

87. It is notable that Justice O'Connor authored the judgments of the Court in both Croson and Adarand. As such, while her Wygant concurrence is not controlling precedent per se, it is likely that Justice O'Connor's discussion of "compelling" remedial interests in Wygant continues to inform the Court's understanding of affirmative action jurisprudence today.

88. Wygant, 476 U.S. at 289 (O'Connor, J., concurring).

89. Id. at 290-91.

90. It bears mention that the law is unsettled regarding what exactly constitutes such a prima facie Title VII claim. Shedding light on the rough contours of such a claim is critically important, however, since it is this statutory benchmark that does the heavy lifting for federal courts when determining whether a compelling remedial interest exists in workplace affirmative action cases. 1t is remarkable, however, that despite doctrinal uncertainty surrounding the makeup of a prima facie statutory violation, federal affirmative action decisions typieally fail to flesh out the very standard that they are using to assess remedial need. 
affirmative action. ${ }^{91}$ Second, when explaining the relatively complicated process of burden shifting operative in reverse discrimination challenges, Justice O'Connor implied that statistical proof of disparity alone could "supply[] the court with the means for determining that the Board had a firm basis for concluding that remedial action was appropriate." $" 92$

The most common type of Title VII claim involves an alleged "pattern or practice" of intentional discrimination. In order to establish a prima facie "pattern or practice" claim, the plaintiff must "establish by a preponderance of the evidence that racial discrimination was the standard operating procedure-the regular rather than the unusual practice." Int'l Bhd. of Teamsters v. United States, 431 U.S. 324, 336 (1977). A prima facie showing, however, does not itself establish a statutory violation of discrimination; rather, it merely creates a rebuttable inference of discrimination. For this reason, the Supreme Court has described the burden of establishing a prima facie statutory violation as "minimal," St. Mary's Honor Ctr v. Hicks, 509 U.S. 502, 506 (1993), and "not onerous." Texas Dep't of Cmty Affairs v. Burdine, 450 U.S. 248, 253 (I981). Furthermore, the Supreme Court has held that a prima facie case can be established solely through evidence of gross statistical disparity: "Where gross statistical disparities can be slown, they alone may in a proper case constitute prima facie proof of a pattern or practice of discrimination." Teamsters, 431 U.S. at 339; accord Hazelwood Sch. Dist. v. United States, 433 U.S. 299, 307 (1977) ("[S]tatistics can be an important source of proof in cmployment discrimination cases ...."). Courts, however, have been unclear regarding exactly what is mcant by "gross statistical disparities." Some courts have suggested that statistical deviations reaching two or three standard deviations from the expected value are highly probative of finding "gross disparity." Hazelwood, 433 U.S. at 309 n.14 ("“[A]s a general rule for such large samples, if the difference between the cxpected value and the observed number is greater than two or three standard deviations,' then the hypothesis that teachers were hired without regard to race would be suspect.") (quoting Castaneda v. Partida, 430 U.S. 482, 497 n.17 (1977)); Waisome v. Port Auth., 948 F.2d 1370, 1376 (2nd Cir. 1991) ("Social scientists consider a finding of two standard deviations significant, meaning there is about one chance in 20 that the explanation for the deviations could be random .... A finding of two or three standard deviations (one in 384 chance the result is random) is generally considered highly probative of discrimmatory treatment.") (citation omitted); Payne v. Travenol Labs., Inc., 673 F.2d 798, $821 \mathrm{n.32}$ (5th Cir. 1982) ("Statisticians tend to discard chance as an explanation for a result when deviations from the expected value approach two standard deviations."). Nevertheless, courts have also been careful to observe that no hard and fast rules exist regarding how many "standard deviations" constitute a prima facie case. Watson v. Fort Worth Bank \& Trust, 487 U.S. 977,996 n.3 (1988) ("We have not suggested that any particular number of 'standard deviations' can determine whether a plaintiff has made out a prima facie case in the complex arca of employment discrimination."); Palmer v. Schultz, 815 F.2d 84, 92 (D.C. Cir. 1987) (insisting that the Supreme Court has not set an "exact legal threshold at which statistical evidence, standing alone, establishes an inference of discrimination"); EEOC v. Am. Nat'l Bank, 652 F.2d 1176, 1192 (4th Cir. 1981) ("[C]ourts...should be extremely cautious in drawing any conclusions from standard deviations in the range of one to three."). Given this confusion regarding the precise makeup of a prima facie statutory violation, it should not be terribly surprising that lower federal courts are conflicted when it comes to determining whether claims of discrimination rise to the level of a "strong basis in evidence."

91. Wygant, 476 U.S. at 292.

[T]he public employer must have a firm basis for determining that affirmative action is warranted. Public employers are not without reliable benchınarks in making this determination. For example, demonstrable evidence of a disparity between the percentage of qualified blacks on a school's tcaching staff and the percentage of qualified minorities in the relevant labor pool sufficient to support a prima facie Title VIl pattern or practice claim by mimority teachers would lend a compelling basis for a competent authority such as the School Board to conclude that implementation of a voluntary affirmative action plan is appropriate to remedy apparent prior employment discrimination.

Id.

92. Id. at 293. 
When Justice O'Connor's concurrence is considered in tandeln with Justice Powell's plurality, Wygant warrants three doctrinal conclusions: (1) employers need not evidence prior discrimination rising to the level of a constitutional or statutory violation before implementing voluntary affirmative action programs; (2) evidence of prior discrimination rising to the level of a prima facie statutory violation will provide a "sufficient basis" for implementing remedial programs; and (3) statistical evidence of minority underrepresentation $\mathrm{im}$ an employer's ranks is highly relevant to a finding of remedial need. With these doctrinal conclusions, however, comes ambiguity. While prima facie statutory violations are sufficient to warrant remedial need, are they necessary? Can anything short of a prima facie statutory violation serve as a "strong basis in evidence" for implementing a voluntary affirmative action program? Furthermore, while statistical showings of minority underrepresentation are clearly relevant to a finding of remedial need, can statistics alone establish such a need? If so, at what level of statistical disparity has the threshold of "a strong basis in evidence" been crossed?

\section{City of Richınond v. J.A.Croson Co.}

While the Croson Court grappled with some of the questions left unresolved in Wygant, it still left ambiguous the question of what constitutes a "compelling" remedial interest. At issue in Croson was a "Minority Busmess Utilization Plan" adopted by the city of Richınond, which required "prime contractors to whom the city awarded construction contracts to subcontract at least 30 percent of the dollar amount of the contract to one or more Minority Business Enterprises (MBEs). ${ }^{n 93}$ As evidence of a compellimg remedial need for this plan, Richınond pointed to various forms of past discrimination that barred minorities from participating in the local contracting mdustry and to the fact that minorities received only 0.67 percent of city contract dollars despite comprising 50 percent of the local population. Nevertheless, the Court struck down this provision, holding, among other things, that this evidence of past discrimination was insufficient to establish a compelling remedial interest. ${ }^{94}$

Writing for the majority, Justice O'Connor reiterated Wygant's holding that "the Equal Protection Clause required 'some showing of prior discrimination by the governmental unit involved." 95 She then declared: "[F]or the governmental imterest im remedying past discrimination to be triggered 'judicial, legislative, or administrative findings of

93. 488 U.S. 469,477 (1989). MBEs were defined as a "business at least fifty-one (51) percent of which is owned and controlled ... by minority group members." Id. at 478 . Such "minority group members" included: "[c]itizens of the Umited States who are Blacks, Spanish-speaking, Orientals, Indians, Eskimos, or Aleuts." Id.

94. Id. at 500 .

95. Id. at 492 (quoting Wygant, 476 U.S. at 274 (1986)). 
constitutional or statutory violations' must be made. Only then does the government have a compellimg imterest im favoring one race over another."96 At first, this statement appears to require, at a minimum, an identifiable statutory violation before a governmental unit may voluntarily engage in affirmative action. Later im the opinion, however, Justice O'Connor examined the city's findings of historical discrimination and concluded: 'None of these 'findings,' singly or together, provide the city of Richmond with a 'strong basis in evidence for its conclusion that remedial action was necessary.' There is nothing approaching a prima facie case of a constitutional or statutory violation by anyone in the Richmond construction industry."97 Framing Richmond's evidence as "nothing approaching" a prima facie statutory violation suggests that Justice O'Connor viewed it unnecessary to isolate a statutory violation before adopting a race-conscious affirmative action plan; for the reasons articulated in Wygant, ${ }^{98}$ a prima facie statutory violation alone was sufficient. The language of "nothing approaching" further suggests that Justice O'Connor might have been willing to accept the city's minority set-aside program if it had simply been better evidenced, even if that evidence fell short of a prima facie statutory violation. ${ }^{99}$

Croson also fails to clarify how governmental actors are expected to measure historical discrimination. Justice O'Connor, for example, explicated the test for analyzing statistical showings of discrimination in the following way: "Where there is a significant statistical disparity between the number of qualified minority contractors willing and able to perforin a particular service and the number of such contractors actually engaged by the locality or the locality's prime contractors, an inference of discriminatory exclusion could arise."100

96. Id. at 497 (citations omitted) (quoting Regents of the Univ. of Cal. v. Bakke, 438 U.S. 265, 307 (1978) (Powell, J., plurality opinion)).

97. Id. at 500 (citations omitted) (quoting Wygant, 476 U.S. at 277).

98. Supra note 89 and accompanying text.

99. Of course, it may also be that by saying "there is nothing approaching a prima facie ... statutory violation," Justice O'Connor meant simply to emphasize Richmond's paucity of evidence. This, in fact, seems to be the interpretation of Professor Reva Siegel, who comments that "[t]he [Croson] Court held that before Richmond could adopt a remedial affirmative action plan, it would have to establish at least a prima facie case that there was discrimination in the bidding process." Reva B. Siegel, The Racial Rhetorics of Colorblind Constitutionalism: The Case of Hopwood v. Texas, in RACE AND RePresentation, supra note 12, at $68 \mathrm{n} .89$. It is not so clear, however, that Justice O'Connor in fact demanded even a prima facie statutory violation. Her language of "nothing approaching" might have been a throwback to the policy consideration articulated by her $W y g a n t$ concurrence; maybe she was still concerned that by requiring employers to isolate a prima facie constitutional or statutory violation, employers would be deterred from voluntarily adopting appropriate remedial programs. Either way, divergent lowcr court opinions reveal that this is an unsettled area of law; while some courts demand (at a minimum) a prima facie statutory violation, others are content that a "compelling" interest exists so long as the governmental actor marshals evidence "approaching" such a violation. See infra Part II.B.

100. Croson, 488 U.S. at 509. 
Justice O'Connor's formulation, however, provides hittle guidance for how this comparative measurement of discrimination should proceed. Initially, it is unclear exactly what constitutes "a significant statistical disparity." The Court provides little direction as to how mucli disparity is enough to prove a historical violation and little guidance for public entities seeking to devise a constitutionally sufficient diversity study. Additionally, while Justice O'Connor's test obviously considers statistical analysis to be relevant, she fails to define clearly what she means by an "inference of discriminatory exclusion." She might mean that statistics alone can evidence a compelling remedial interest; ${ }^{101}$ on the other hand, she might mean, as Professor George La Noue has interpreted her, that an "inference of discrimination" does not independently rise to the level of a historical violation and that "[w]ithout more information, [statistics alone] usually cannot identify the source of discrimination or provide a basis for a 'narrowly tailored' remedy."102 Finally, the Court does not clarify how public actors should go about measuring "statistical disparity." Admittedly, Justice O'Connor offers public employers some gnidance on this question:

In the employment context, we have recognized that for certain entry level positions or positions requiring minimal training, statistical comparisons of the racial composition of an employer's work force to the racial composition of the relevant population may be probative of a pattern of discrimination. But where special qualifications are necessary, the relevant statistical pool for purposes of demonstrating discriminatory exclusion must be the number of minorities quahified to undertake the particular task. ${ }^{103}$

This methodological exhortation, however, suffers from the same ambiguity affecting her previous suggestion that statistical comparisons should only consider those minorities "willing and able" to perform the job. Does

101. At one point in her decision, for example, Justice O'Connor declares: "There is no doubt that '[w]here gross statistical disparities can be shown, they alone in a proper case may constitute prima facie proof of a pattern or practice of discrimination' under Title VII." Id. at 501 (quoting Hazelwood Sch. Dist. v. United States, 433 U.S. 299, 307-08 (1977)). While this seems fairly straightforward, it is not clear what Justice O'Connor means by "in a proper case." She offers no clear guidance for determining exactly when such a "proper case" exists, and as such, it reinains uncertain exactly when statistics alone can evidence a coinpelling state interest.

102. George R. La Noue, Standards for the Second Generation of Croson-Inspired Disparity Studies, 26 URB. LAw. 485, 487 (1994).

103. Croson, 488 U.S. at 501-02 (citations omitted). For additional Court guidance on when "special qualifications are necessary", see Hazelwood School District, 433 U.S. at 307-09 (finding that prima facie proof of racially discriminatory einployment practice may be based on gross statistical disparity between racial composition of public school district's teaching staff and racial composition of qualified public school teacher population in relevant labor market; but, where job qualifications are ones that many persons possess or can easily acquire, it is proper to compare the employer's work force with the nndifferentiated local labor pool); Int'l Bhd. of Teamsters v. United States, 431 U.S. 324, 337 39 (1977) (finding that statistical disparity between the percentage of minority truck drivers in an einployer's work force and the percentage in the general population was highly probative of discrimination). 
Justice O'Connor's "relevant statistical pool" mean that public employers should compare only those minorities that applied for the job and those that were accepted? Or does this standard allow a broader examination of qualified minorities in the local labor pool?

This collective ambiguity ${ }^{104}$ has led cominentators to observe that "Croson does not provide a complete blueprint" for identifymg historical discrimination in a constitutionally sufficient manner. ${ }^{105}$ I therefore now turn to the lower federal courts to see how they have grappled with this doctrinal uncertainty.

\section{B. Defining Remedial Interests as "Compelling" in the Lower Federal}

\section{Courts}

\section{How Much Discrimination is Sufficient to Justify Affirmative Action?}

The dominant narrative implies that lower federal courts would resolve the foregomg ambiguity in ways that subvert, or at least substantially limit the scope of, remedial affirmative action programs. Some courts have moved im this direction, but many others have carved out substantial space for race-conscious programs. Thoroughly understanding this jurisprudential development will take some time. Nevertheless, examining where the lower federal courts have set the bar for historical showings of discrimination is the first analytic step towards a more accurate understanding of modern affirmative action doctrine.

104. An ambiguity that 1 have not discussed deserves brief mention, for it further illustrates the doctrinal uncertainty left in Croson's wake. Immediately after Justice O'Connor declared the need for "some showing of prior discrimination by the governmental unit involved," she suggested that "if the city could show that it had essentially become a 'passive participant' $m$ a system of racial exclusion practiced by elements of the local construction industry, we think it clear that the city could take affirmative steps to dismantle such a system." Croson, 488 U.S. at 492 . Arguahly, this leads one to question whether the public agent adopting the affirmative action policy must itself have heen guilty of historical discrimination. The relevance of this statement in the employment context, however, is uncertain at best. Remember that Croson involved a government locality using public funds to promote affirmative action in the private construction sector. In such instances, Justice O'Connor declared: “It is beyond dispute that any public entity, state or federal, has a compelling interest in assuring that public dollars, drawn from the tax contributions of all citizens, do not serve to finance the evil of private prejudice." Id. In the employment context, however, most cases involve a public employer (for example, a police or fire department) that has adopted an affirmative action policy in its hiring, firing, or promotion decisions. In such cases, it would be difficult to einploy the "passive participant" argument since the only discriminatory agent in question is the state actor itself. For an exploration of what this "passive participant" equivocation might mean in practice, see Ian Ayres \& Fredrick E. Vars, When Does Private Discrimination Justify Public Affirmative Action?, 98 Colum. L. REv. 1577 (1998).

105. La Noue, supra note 102, at 485. See also Nicole Duncan, Croson Revisited: A Legacy of Uncertainty in the Application of Strict Scrutiny, 26 ColuM. HuM. RTS. L. Rev. 679 (1995); Cassandra D. Hart, Unresolved Tensions: The Croson Decision, 7 HARV. BlackLETTER L.J. 71 (1990); Douglas D. Scherer, Affirmative Action Doctrine and the Conflicting Messages of Croson, $38 \mathrm{U}$. KAN. L. REv. 281 (1990). 
When federal courts examine a remedial affirmative action plan, they must as a threshold matter determine the appropriate standard of mquiry. The black letter law suggests that discrimination must have a "strong basis m evidence" to justify remedial action, but this ostensibly simple axiom is ambiguous. How strictly a court imterprets this doctrinal aphorism largely dictates the sort of evidence that a court will require for establishing that a compelling remedial need exists for race-conscious affirmative action. For example, we will see that the deferential "approaching a prima facie ... statutory violation" standard might im part explain why a court is willing both to find present effects of past discrimination and to accept relatively limited showings of statistical disparity. ${ }^{106}$ This section will first

106. A good example of this deferential attitude can be found in the First Circuit's Boston Police Superior Officers Federation v. City of Boston decision, 147 F.3d 13 (1st Cir. 1998). In 1994, the Boston Police Department (BPD) announced that it would promote twenty sergeants to the rank of lieutenant and that these promotions would be based on the results of a previously administered civil service exam. Upon realizing that strict adherence to test scores would promote eighteen white officers and only two blacks, the BPD elected to promote an African American, whose test score was the twenty-first highest, in place of three white sergeants whose test scores tied for the twentieth highest score. The passed over white sergeants filed suit contending that the race-conscious promotion violated their constitutional rights. Upon evaluating this clain, the court asserted: "The 'strong basis' may consist of either 'a contemporaneous or antecedent finding of past discrinination by a court or other coinpetent body,' or evidence 'approaching a prima facie case of a constitutional or statutory violation." Id. at 20 (quoting Wygant, 476 U.S. at 289 (O'Counor, J., concurring) and Croson, 488 U.S. at 500). After invoking this standard, the court examined the evidence of discriunination. Finding evidence of racial exclusion stretching from the early 1970 s to the early 1990 s, the court inferred present discrimmatory effects from this past discrimination. While Judge Campbell acknowledged the need to be "wary ... . of remedial measures that are "ageless in their reach into the past, and timeless in their ability to affect the future," Id. at 20-21 (quoting Wygant, 476 U.S. at 276), he insisted: "[R]emedial action takes time.... and discrimination may linger for many years in an organization that had excluded blacks from its ranks." Id. at 20 (quoting Stuart v. Roache, 951 F.2d 446,452 (1st Cir. 1991). Because there was a history of discrimination in the promotion of sergeants, and because lieutenants were promoted solely froin the sergeants' ranks, Judge Campbell concluded that "discrimination in promotions to sergeant reduced the pool of blacks ehigible to compete for promotions to lieutenant." Id.

In so finding, the Boston Police court sustained the First Circuit practice of reading an entry-level violation to justify a promotion-level remedy. Accord Ensley Branch, NAACP v. Seibels, 31 F.3d 1548, 1566-67 (11th Cir. 1994) ("A natural consequence of discrimination against blacks at entry-level positions in the police and fire departments would be to limit their opportunities for promotion to higher levels in the departments."); In re Birmingham Reverse Discrimination Employment Litig., 20 F.3d 1525, 1540 (11th Cir. 1994) ("[B]lacks were not represented at all in the . . lieutenant ranks as a direct result of discriminatory testing for entry-level positions."); Stuart, 951 F.2d at 452 ("[L]itigated court findings of recent entry-level discrimination would seem sufficient to justify race-conscious remedies at both entry and promotional levels."); Krupa v. New Castle County, 732 F. Supp. 497, 512 (D. Del. 1990) (finding that with adequate evidence, "the County inay argue that the statistical imbalance in the percentage of swom officers to the percentage of minorities in the community indicates past discrimination in hiring and that this discrimination in hiring serves as a predicate for the dearth of inmorities qualified for cominand positions"). It is noteworthy that the Boston Police court came to this conclusion despite the BPD's good-faith compliance with a consent decree dating back to 1978. This raises the larger doctrinal point of the relevance of (unsuccessful) efforts taken by the governmental unit imvolved to remedy past discrimination short of affirmative action. While a full examination of this issue is beyond the scope of this Comment, consider the legal implication of adopting EEOC validated promotions exams: compare, for example, the position taken by the Boston 
examine the diverse standards of review employed by the federal judiciary and then will canvass the varied showings of discrimination that either have, or have not, sufficed to present a "strong basis in evidence."

\section{a. The Standard of Review: Defining a "Strong Basis in Evidence"}

A review of the cases in this area reveals that courts approach this definitional task in one of three ways. First, most courts fail to engage the task at all; most simply declare the facile "strong basis in evidence" requirement and proceed to evaluate the presented documentation of discrimination. ${ }^{107}$ While this approach is understandable given the Court's uncertain pronouncements, this failure to define the "strong basis" requirement makes it difficult to discern exactly where along the continuum of discrimination a government actor can constitutionally locate a "compelling" remedial interest. Second, some courts adopt an explicitly deferential standard. This is discernible either in very general terms, ${ }^{108}$ or by explicitly adopting the "approaching a prima facie... statutory violation" standard seen previously in Croson. ${ }^{109}$ While courts infrequently

Police court, 147 F.3d at 21 ("[P]ast discrimination, if sufficiently pervasive, may justify consideration of race in promotions even when candidates have taken a validated exam. ... '[V]alidated exams are not an end in themselves but merely a means toward achieving the decree's actual objective: rough parity (to remedy the effects of past discrimination)'") (quoting Mackin v. City of Boston, 969 F.2d 1273, 1277 (1st Cir. 1992)), with the position taken in at least one district court, Lalla v. City of New Orleans, 1999 WL 138900, at *2 n.10 (E.D. La. Mar. 12, 1999) (holding that validated exains preclude the City from "justify[ing] the remedial action on the basis that the fire recruit exam had a disparate impact on black applicants").

107. See Middleton v. City of Flint, Michigan, 92 F.3d 396, 404 (6th Cir. 1996); Edwards v. City of Houston, 37 F.3d 1097, 1113 (5th Cir. 1994); Seibels, 31 F.3d at 1565; In re Birmingham, 20 F.3d at 1544; Md. Troopers Ass'n v. Evans, 993 F.2d 1072, 1076 (4th Cir. 1993); Jansen v. City of Cincinnati, 977 F.2d 238, 242 (6th Cir. 1992); United Black Firefighters Ass'n v. City of Akron, 976 F.2d 999, 1009 (6th Cir. 1992); Vogel v. City of Cincinnati, 959 F.2d 594, 599 (6th Cir. 1992); Donaghy v. City of Omaha, 933 F.2d 1448, 1458 (8th Cir. 1991); Long v. City of Saginaw, 911 F.2d 1192, 1196 (6th Cir. 1990); Howard v. McLucas, 871 F.2d 1000, 1007 (11th Cir. 1989); Lalla, 1999 WL 138900, at *2; Majeske v. City of Chicago, 29 F. Supp. 2d 872, 874 (N.D. Ill. 1998); Hiller v. County of Suffolk, 977 F. Supp. 202, 206 (E.D.N.Y. 1997); Freeman v. City of Fayetteville, 971 F. Supp. 971 , 975 (E.D.N.C. 1997); Koski v. Gainer, 1995 WL 599052, at *13 (N.D. Ill. Oct. 5, 1995); Sims v. Montgomery County Comm'n (Sims II), 887 F. Supp. 1479, 1487 (M.D. Ala. 1995); Sims v. Montgomery County Comm'n (Sims I), 873 F. Supp. 585, 604 (M.D. Ala. 1994); N. State. Law Enforeement Officers Ass'n v. Charlotte-Mecklenburg Police Dep't, 862 F. Supp. 1445, 1457 (W.D.N.C. 1994); Houston Chapter of tbe Int'l Ass'n of Black Profl Firefighters v. City of Houston, 1991 WL 340296, at *31 (S.D. Tex. May 3, 1991); Krupa, 732 F. Supp. at 510-11 (D. Del. 1990).

108. See, e.g., Erwin v. Daley, 92 F.3d 521, 527-28 (7th Cir. 1996) (highlighting the varied ways in which federal courts have found government interests in affirmative action "compelling" after Croson).

109. E.g., Peightal v. Metro. Dade County (Peightal I), 940 F.2d 1394, 1403-04 (11th Cir. 1991) (holding that while state actors "must identify ... discrimination, public or private, with some specificity before they may use race-conscious relief," this burden can be met by "producing evidence that the statistical disparity between the relevant employee and work force populations is at least 'approaching a prima facie case of a constitutional or statutory violation"') (quoting Croson, 488 U.S. at 505, 500); Peightal v. Metro. Dade County (Peightal II), 26 F.3d 1545, 1553 (11th Cir. 1994) ("In assessing whether the governmental unit has a 'strong basis in evidence' for imposing race-conscious 
exhibit such deference, when they do, the "strong basis" requirement generally reflects a green hight for governmental agents to voluntarily adopt affirmative action programs on very modest evidential showings of remedial need. ${ }^{110}$ Fmally, some courts isolate a prima facie statutory violation as the benchmark of a "strong basis in evidence." Most courts pursuing this approach do so when there is clear documentation of discrimination; in such cases, they uncontroversially assert that a prima facie statutory violation constitutes a sufficient showing of discrimination to find a "strong basis" for remedial action. ${ }^{111}$ At least one federal district, however, has pushed this argument even further, declaring that remedial programs must, at minimum, evidence a prima facie statutory violation. ${ }^{112}$

\section{b. The Mechanics of Presenting a "Strong Basis in Evidence"}

Despite the lack of a clear standard for a "strong basis im evidence," most successful claims of discrimination have involved a statistical showing of disparity calculated by comparing the employer's work force

relief, the proffered evidence must 'approach[] a prima facie case of a constitutional or statutory violation."') (quoting Croson, 488 U.S. at 500).

110. E.g., supra note 109. But see Kane v. Freeman, 1997 U.S. Dist. LEXIS 4063, at *16 (M.D. Fla. Mar. 17, 1997) (invoking the osteusibly deferential "approaching a prima facie case" standard, but then using it to find statistical evidence insufficient for establishing a "strong basis" for remedial need).

111. E.g., Aiken v. City of Memphis, 37 F.3d 1155, 1163 (6th Cir. 1994) ("It is settled that '[a]ppropriate statistical evidence setting forth a prima facie case of discrimination is sufficient to provide a strong basis in evidence to support a public employer['s] action plan.") (quoting Brunet v. City of Columbus, 1 F.3d 390, 407 (6th Cir. 1993); Officers for Justice v. Civil Serv. Comm'n, 979 F.2d 721, 726 (9th Cir. 1992) ("Statistical evidence of disparity sufficient to support a prima facie case under Title VIl may, in some cases, constitute a strong basis in the evidence for believing that a voluntary affirmative action program was required by, and consistent with, the Constitution."); Davis v. City \& County of San Francisco, 890 F.2d I438, 1446-47 (9th Cir. 1989) ("[S]tatistical disparities between the numbers of minorities and women hired in the fire department and the numbers of minorities and women residing in the City constituted a 'strong basis in evidence' sufficient to establish a prima facie case of past discrimination and justify the affirmative action provisions. ..."); United States v. City of Hialeah, 899 F. Supp. 603, 608 (S.D. Fla. 1994) ("The requisite evidentiary basis for race-conscious relief exists if there is sufficient evidence to establisli a prima facie case of discrimination in violation of Title VII."), affd, 140 F.3d 968 (11th Cir. 1998); Paganucci v. City of New York, 785 F. Supp. 467, 477 (S.D.N.Y. I992) ("It is well settled that a statistical disparity sufficient to support a prima facie claim under Title VII provides a firm basis for the implenentation of a race-conscious remedy."), aff'd, 993 F.2d 310 (2d Cir. 1993).

I12. E.g., Allen v. Ala. State Bd. of Educ., 976 F. Supp. 1410, 1429 (M.D. Ala. 1997) ("The governmental body must have a 'strong basis in evidence for its conclusion that remedial action was necessary.' The test can be formulated as requiring 'a prima facie case of a constitutional or statutory violation.") (citation omitted), aff'd, 164 F.3d 1347 (I1th Cir. I999); Shuford v. Ala. State Bd. of Educ., 846 F. Supp. 1511, 1521 (M.D. Ala. 1994).

Whether race-conscious rehef serves a remedial purpose with respect to past discrimination is an evidentiary issue. ... [T] There must be a "strong basis in evidence" for the conclusion that the decree remedies past discrimination. The requisite evidentiary basis has also been described as "a prima facie case of a constitutional or statutory violation."

Id. (citation omitted). 
with the composition of the "relevant" local population. ${ }^{113}$ While this Comment will later explore the parameters of what constitutes a "relevant" population, ${ }^{114}$ the following standard articulated by the Sixth Circuit represents the typical doctrinal formulation:

The method generally used is to compare the minority percentage in the relevant statistical pool to the mimority percentages in the group of persons selected for the positions at issue. The relevant statistical pool is comprised of all persons qualified for the position at issue. Roughly the same percentage of minorities observed in the relevant statistical pool should also be observed in the group of persons selected for the position at issue..$^{115}$

While this formula offers a means of measuring statistical disparity, that is, the difference between the expected number of minorities in a given work force and their actual work place percentage, it fails to quantify how much disparity is necessary to constitute a "strong basis in evidence."

113. For the Supreme Court's explication of this method for statistical comparison, see supra note 100. For the rare exception where a court recognizes a "strong basis in evidence" without such statistical evidence, see Shuford, 846 F. Supp. at 1527 (M.D. Ala. 1994) ("[T]he Shuford class has provided both anecdotal and historical evidence identifying in detail a substantial body of facts reflecting that racial discrimination ... is manifest, pervasive, and deeply intransigent .... Therefore, even without statistical evidence, the Shuford class has more than met its burden under Croson."). Despite this assertion, however, the court proceeded to examine employment statistics, showing the power of statistical evidence in this doctrinal context.

114. Infra Part II.B.3.

115. United Black Firefighters Ass'n v. City of Akron, 976 F.2d 999, 1011 (6th Cir. 1992) (citations omitted).

116. While this generally is the critical question for the first prong of equal protection analysis, at least two courts have posed this question in different ways. First, in Aiken v. City of Memphis, 37 F.3d 1155 (6th Cir. 1994), the court was presented with an affirmative action promotion scheme for sergeants in the Meinphis Police Department and senior firefighters in the Memphis Fire Department. To justify this program, the city eompared the amount of black patrol officers and junior firefighters with the amount of black sergeants and semor firefighters, finding enough disparity to isolate "a pattern of racial discrimination in promotions." Id. at 1163 . Plaintiffs asserted that these disparities could not afford a "strong basis" for discrimination because the "statistics are based upon an overbroad labor pool, since not all patrol officers and fire privates are qualified for promotion to the next rank." Id. While the court conceded the plaintiffs' argument, it inexplicably insisted that the argument carried no weight: "[T] he compelling interest inquiry focuses simply on whether discrimination occurred, not on the precise extent of any discrimination that did occur. Thus, we conclude that the statistics presented here are probative enough to satisfy the City's burden of producing strong evidence that discrimination occurred in the Memphis Police and Fire Departments." Id. This cannot be right. It cannot be that any showing of discrimination is enough to satisfy the compelling interest inquiry, for even the inost deferential reading of Wygant and Croson would still require a showing of discrimination "approaching a constitutional or statutory violation." Issues of doctrinal fidelity aside, however, this decision does represent a startling level of deference to the City of Memphis, deference that is usually absent from strict scrutiny review.

Second, in McNamara v. City of Chicago, 138 F.3d 1219 (7th Cir. 1998), the court was faced with an affirmative action promotions plan for black and Hispanic captains in the Chicago Fire Department. While Judge Posner did consider the statistical disparity of excluded minorities, rather than assess whether this disparity constituted a sufficiently "strong basis" for a flnding of discrimination, he merely inquired as to whether the remedy exceeded the violation; that is, Judge Posner merely asked whether the scope of the remedial affirmative action program exceeded the scope 
The cases with manifest evidence of stark remedial need provide a starting point for understanding how courts assess "compelling" statistical disparity. Consider, for exanıle, the Eleventh Circuit's Peightal cases. In Peightal $I$, Dade County, Florida implemented an affirmative action program for entry level firefighters. The court assessed remedial need simply by ascertaining the percentage of minorities in Dade County $(35.8 \%)$ and multiplying that percentage by the number of actual firefighters (921) to derive the expected number of minorities on the firefighter force (330). The court found that a comparison of this expected number to the actual number (127) "reveals a statistical disparity far in excess of two or three standard deviations"117 (in this case, fourteen standard deviations) and thus supportive of a "strong basis in evidence" finding. In Peightal $I I,{ }^{118}$ the appellate court was presented with similarly bleak statistics. At trial, Dade County defended its affirmative action program by comparing the actual number of minorities in the fire department with the expected percentage (given the percentage of blacks and Hispanics in the qualified labor pool) ${ }^{119}$ In 1970, the fire department employed 977 whites, 27 blacks, and 17 Hispanics; statistical estimates for the expected workforce were 497 white, 167 black, and 347 Hispanic. ${ }^{120}$ By 1983, the gaps between these sets of numbers had narrowed, but not by much: actual employment was 757 white, 127 black, and 147 Hispanic; expected employment was 387 white, 187 black, and 427 Hispanic. ${ }^{121}$ The disparity of blacks was calculated to be 4.8 standard deviations and the disparity of Hispanics to be 17.6 standard deviations. ${ }^{122}$ On appeal, the plaimtiff contested ouly the Hispanic affirmative action program; in light of such stark statistical

of the identifiable discrimination. Since it did not, Chicago's plan was constitutional. "[ $[\mathrm{T} t$ could be argued that the City must demonstrate a compelling interest in ... [the] increase [of minority captains]," id. at 1224, Judge Posner declared:

But that would be the wrong approach in a case in which the justification for affirmative action is remedial. The test is, rather, whether the increase is a plausible lower-bound estimate of a shortfall in minority representation among fire captains that is due to the fire department's intentional discrimination in the past.

Id. While the inplications of Judge Posner's novel approach are difficult to determine, it arguably is deferential in that it allows remedial affirmative action upon any showing of discrimination, subject to the limits of narrow tailoring. For a case that follows Judge Posner's novel approach, see Majeske $v$. City of Chicago, 29 F. Supp. 2d 872, 878 (N.D. 11l. 1998) (finding a remedial plan "narrowly tailored" kecause "the out-of-rank order promotion[s] ... constituted a plausible lower-bound estimate of the shortfall in minority representation among detectives that was due to the police department's intentional discrimination in the past").

117. Peightal I, 940 F.2d 1394, 1406 (11th Cir. 1991). For a discussion of the relevance of "standard deviations" to statistical showings of disparity, see supra note 90.

118. 26 F.3d 1545 (11th Cir. 1994).

119. Id. at 1550.

120. Id.

121. Id.

122. Id. 
disparity, however, the court found race-conscious measures to be justified by remedial need. ${ }^{123}$

Although the Peightal cases represent the outer edge of statistical disparity, their doctrinal methodology, or pro-affirmative action tenor, is by no means anomalous. Several jurisdictions beyond the Eleventh Circuit, for example, have tacitly accepted the two or three standard deviations rule, generally finding a "strong basis" for remedial action when disparity rises past this statistical benchmark. ${ }^{124}$ Furthermore, though courts rarely see Peightal-level disparity, many have found a "compellimg" remedial need when presented with less egregious statistical showings. ${ }^{125}$ While many of

\section{Id. at 1556 .}

[T] he evidence [showed] that the difference between the expected and actual percentage of Hispanics in the Fire Department ... was 17.6 standard deviations. . . . [This] would occur by chance only once in every one billion cases. Accordingly... [the] evidence of a statistical disparity ... constituted the requisite 'strong basis in evidence' mandated by Croson.

Id.

124. For discussion of the two or three standard deviations rule in the affirmative action context, see United Black Firefighters v. City of Akron, 976 F.2d 999, 1011 (6th Cir. 1992); Vogel v. City of Cincinnati, 959 F.2d 594, 600 (6th Cir. 1992); Koski v. Gainer, 1995 WL 599052, at *14 (N.D. Ill. Oct. $5,1995)$.

125. See Edwards v. City of Houston, 37 F.3d 1097, 1109, 1111 (5th Cir. 1994) ("AfricanAmericans suffercd [a] 64.6\% ... shortfall in Sergeant promotions .... Hispanic-Americans suffered [a] 35.4\% . . . shortfall"; "[N]o objector presented any credible evidence that any factor other than the challenged tests, accounted for any meaningful part of the racial disparities in the promotion rates between the different racial groups."); In re Birmingham Reverse Discrimination Employment Litig., 20 F.3d 1525, 1540 (11th Cir. 1994) ("[T]here were 453 firefighters . . , 42 of whom were black. There were also 94 lieutenants, 31 captains, and 15 battalion chiefs, none of whom were black"; also, "the district court had alrcady found that tests administered by the Board . . . were invalid under Title VII because they had a significant adverse impact on blacks ...."); Officers for Justice v. Civil Serv. Comm'n, 979 F.2d 721, 726 (9th Cir. 1992) (focusing on a history of discrimination, and on an ongoing consent decree adopted after a "prima facie case of discrimination against minorities ... in the upper ranks of the Department," continued "underrepresent[ation] in both entry and promotional ranks," and "results of the 1989 examination [that] reflected an adverse impact on minority candidates"); United Black Firefighters, 976 F.2d at 1010-11 (finding that "only four out of a total of twenty-nine black applicants would receive promotions or 13.8 percent of the black apphicants that successfully passed the examination" while "[f]orty-two out of the eighty-nine white applicants who passed the test would be promoted, which causes the appointment of 47.2 percent of the successful white applicants"); Vogel, 959 F.2d at 600 ("[B]etween 1972 and 1979, 33.7\% of the applicants for entry level police officer positions were black, whereas only $20.4 \%$ of the appointments were black. Moreover, in 1980 only $9.9 \%$ of the swom officers in the Police Department were black while the labor force of the City was $24 \%$ black ...." The court continued: "[T] dhe disparity between the expected rate of black appointments and the actual rate was 4.7 standard deviations. The disparity between the expected and actual numbers of blacks on the Cincinnati police force was 12.5 standard deviations."); Donaghy v. City of Omaha, 933 F.2d 1448, 1451, 1453 (8th Cir. 1991) ("[A]s of October 1980, only $4.3 \%$ of the [Omaha Police Department's] 560 sworn personnel were black . . . of the 170 officers hired since 1972 only 4 officers, or $2.4 \%$ were black; and that of the 42 police officers hired in 1978, none were black . . . ." The court continued: "[П]n April 1988 . . only 3.2\% of the lieutenants were black, while $10.7 \%$ of those eligible to be promoted to lieutenant were black."); Davis v. City and County of San Francisco, 890 F.2d 1438, 1443 (9th Cir. 1989) (finding sufficient a history of discriminatory entry-level tests, where the most recent test "produced a passing rate of $59 \%$ for Blacks, $74 \%$ for Hispanics and $69 \%$ for Asians in relation to the passing rate for White applicants"); Howard v. McLucas, 871 F.2d 1000, 1007 (11th Cir. 1989) (finding "standard deviations of 3.53 to 8.19 in the 
these cases are unsatisfying from a doctrinal perspective, in that their "strong basis" findings often are unmoored from any discernible jurisprudential standard, they do suggest that many more courts are willing to allow racial classifications to address remedial need than the dominant narrative might have us believe.

This is not to say that federal courts have been uniformly willing to find "compelling" the remedial interests asserted by governmental actors. While some courts accept the presented evidence of disparity but ultimately find it insufficient to form a "strong basis in evidence,"126 others

promotion rates for blacks" illustrative of remedial need); Chicago Fire Fighters Union, Local No. 2 v. City of Chicago, 1999 WL 1289125, at $* 67,70$ (N.D. Ill. Dec. 30, 1999) (finding minority underrepresentation that "greatly excceded three standard deviations," anecdotal evidence of past intentional discrimination, and the "lingering effects of the past intentional discrimination ... through at least 1996"); Majeske, 29 F. Supp. 2d at 876-77 (finding evidence of minority underrepresentation coupled with evidence of disparate impact caused by promotions test sufficient to warrant renedial action); Koski, 1995 WL 599052, at *13 (focusing on: statistics showing "that blacks composed only $1.7 \%$ of the state trooper contingency, even though 'the pool of eligible applicants was $14.7 \%$ black"; “"significant statistical disparity' . . for blacks and Hispanics during the early and mid-80's"; written tests that "negatively impacted blacks and other minorities"; and "anecdotal evidence in the form of the numerous complaints filed with both federal and state equal opportunity agencies"); Sims v. Montgoinery County Comin'n (Sims II), 887 F. Supp. 1479, 1487 (M.D. Ala. 1995); Sims v. Montgomery County Comin'n (Sims I), 873 F. Supp. 585, 604-05 (M.D. Ala. 1994) (focusing (in both) on 1988 findings of historical intentional discrimination by the Sheriff Department against minority promotions); Umited States v. City of Hialeah, 899 F. Supp. 603, 609 (S.D. Fla. 1994) (noting that from 1987 to 1994, "the City realized a total shorfall of 16 to 17 persons, between the number of black police officers it hired and the number expected to be hired"; "with regard to the number of black firefighters hired during the same 1987 to 1994 period, the City realized a shortfall of 14 to 15 persons"; and, "entry level pohice and firefighter examinations had an adverse impact on blacks, with pass rates of only $25.2 \%$ and $67.2 \%$, respectively"), aff'd, 140 F.3d 968 (11th Cir. 1998); Shuford v. Ala. State Board of Educ., 846 F. Supp. 1511, 1528 (M.D. Ala. 1994) (focusing on historical and anecdotal evidence, and statistical evidence showing that the State Board's "African-American employment in 1993 ... [was]: $15.1 \%$ of presidents, $17.8 \%$ of deans and business managers, $22.2 \%$ of non-faculty professionals, and $19.0 \%$ of faculty members"); Paganucci v. City of New York, 785 F. Supp. 467, 471 (S.D.N.Y. 1992) ("Although 12.3\% of those who took the Sergeant's Examination were black and $8.7 \%$ were Hispanic, blacks and Hispanics made up only $2.31 \%$ and $4.23 \%$, respectively, of those whose names were placed on the eligible list [for promotion]."), aff d, 993 F.2d 310 (2d Cir. 1993); Houston Chapter of the Int'l Ass'n of Black Profl Firefighters v. City of Houston, 1991 WL 340296, at *14, 5-14 (S.D. Tex. May 3, 1991) (finding the "substantial adverse impact against blacks and against Hispanics" produced by eight promotions exams sufficient to provide a strong basis im evidence; the standard deviations of this mipact ranged from .41 to 10.1).

126. See Md. Troopers Ass'n v. Evans, 993 F.2d 1072, 1078 (4th Cir. 1993) (finding that statistical evidence demonstrated some disparity, but that it evidenced nothing more "than a conclusory finding that the [Maryland State Pohce] had racially discriminated, in hiring or in promotions"); Lalla v. City of New Orleans, 1999 WL 138900, at *2, 2 n.9 (E.D. La. Mar. 12, 1999) (finding the City's statistical evidence that the fire department "was $82 \%$ white compared with $17 \%$ black.... [while] the New Orleans labor force was $59.70 \%$ black" insufficient in light of recent efforts taken to mcrease minority employment and a lack of "any recent anecdotal evidence, prior judicial findings, poor testing methods, or other specific evidence of recent discrimination to support the assertion that the NOFD has recently discriminated against black applicants"); Killebrew v. City of Greenwood, 988 F. Supp. 1014, 1015 (N.D. Miss. 1997) (granting injunction against ongoing race-conscious consent decree because the "defendants have failed to produce any evidence that there are vestiges of past discrimination in the Greenwood Fire Department at the present time"); Freeman v. City of Fayetteville, 971 F. Supp. 971, 
dispute the methodology by which the evidence was gathered. ${ }^{127}$ At times, however, it is difficult to discern the legal principles that separate these holdings from the previous cases that found a "strong basis im evidence." The fact is that many of these decisions are made on a rather ad hoc basis where some courts accept evidence of remedial need that others would not find compelling.

\section{Can Statistics Alone Evidence Remedial Need?}

The foregoing discussion on Croson reveals some ambiguity about whether statistics alone can provide a "strong basis" for remedial action. ${ }^{128}$ Ambiguity aside, however, many federal courts presented with stark statistical disparity have been willing to find remedial need on that basis alone. ${ }^{129}$ The logic of these decisions is as follows: since a prima facie statutory violation (or less) sufficiently provides a "strong basis in evidence" for race-conscious remedial action, ${ }^{130}$ and since statistics alone generally can evidence at least a prima facie statutory violation, ${ }^{131}$ statistics alone arguably suffice to establish an affirmative action program's remedial need.

There is, however, a vocal minority of courts that call this logic into question. Judge J. Harvie Wilkinson, for example, declared in his well known Maryland Troopers decision that

[i]nferring past discrimination from statistics alone assumes the most dubious of conclusions: that the true measure of racial equality is always to be found in numeric

975-76 (E.D.N.C. 1997) (rejecting consent decree, in part, because the judgment affirming the decree failed to adequately evidence prior discrimination); Kane v. Freeman, 1997 U.S. Dist. LEXIS 4063, at *17, 18 (M.D. Fla. Mar. 17, 1997) (finding that because "black candidates for the rank of Lieutenant were promoted at rates that actually exceeds [sic] the percentage of blacks in the rank of Sergeant," and because "black employees are significantly over-represented among [Tampa Police Department's] nonsupervisory employees," there was no gross statistical disparity); Police Ass'n v. City of New Orleans, 1995 WL 311982, at *13 (E.D. La. May 18, 1995) (rejecting the need for race-based promotions because existing race-neutral efforts were solving disparity); N. State Law Enforcement Officers Ass'n v. Charlotte-Mecklenburg Police Dep't, 862 F. Supp. 1445, 1458 (W.D.N.C. 1994) (rejecting police department consent decree, in part, because the claim of disparate impact from applicant testing was insufficiently evidenced).

127. See Middleton v. City of Flint, Michigan, 92 F.3d 396, 406-09 (6th Cir. 1996) (rejecting a "strong basis in evidence" conclusion beeause the statistical disparity compared the percentage of those minorities promotcd to the rank of police sergeant to that of local Flint minorities, rather than comparing the proportion of minority sergeants to the proportion of minority police officers currently on the force); Long v. City of Saginaw, 911 F.2d 1192, 1199 (6th Cir. 1990) (rejecting statistical showings of disparity because they "erroneous[ly]" rely on an "undifferentiated work force statistic to support a prima facie case of employment discrimination"); Krupa v. New Castle County, 732 F. Supp. 497,514 (D. Del. 1990) (finding no strong basis in evidence because findings of discrimination "were premised on disparities based on general population statistics").

128. See supra Part II.A.2.

129. Supra Part II.B.1.

130. Supra Part II.A.2.

131. Supra note 90. 
proportionality....[O]nly when there are "gross statistical disparities" between the racial composition of the employer's workforce and the racial composition of the relevant qualified labor pool may the court infer that the employer has racially discriminated. And even then, when the Supreme Court has approved a race-conscious remedy on the basis of such comparisous, the statistics have been corroborated by significant anecdotal evidence of racial discrimination. ${ }^{132}$

While Judge Wilkinson seems to be in the minority on this point, his approach has influenced other courts. The District Court for the Eastern District of Louisiana, for example, illustrates this trend. Early in the court's Lalla v. City of New Orleans decision, it quoted Croson for the proposition that "[w] here gross statistical disparities can be shown, they alone in a proper case may constitute prima facie proof of a pattern or practice of discrimination."133 After canvassing the City's evidence of disparity, however, the court concluded that "statistics alone are insufficient to constitute a "strong basis in evidence."'134 Justification for this bold declaration stemmed from two circuit decisions. In one, Judge Boggs held:

[D]isparity between the percentage of a protected class employed in a particular workforce... and the raw percentage of class meinbers in a regional labor pool, standing alone, cannot be a 'strong basis in evidence'.... [I]t is permissible to reinedy discrimination. It is not permissible to remedy disparity, without more. ${ }^{135}$

In the other, Judge Posner insisted that "[r]aw statistical disparities prove little; they certainly do not prove intentional discrimination."136

132. Md. Troopers Ass'n v. Evans, 993 F.2d 1072, 1077 (4th Cir. 1993) (citation omitted).

133. 1999 WL 138900, at $₹ 2$ (E.D. La. Mar. 12, 1999) (quoting City of Richmond v. J.A. Croson, 488 U.S. $469,501(1989))$.

134. Id. at $* 4$.

135. Middleton v. City of Flint, Michigan, 92 F.3d 396, 406 (6th Cir. 1996).

136. McNamara v. City of Chicago, 138 F.3d 1219, 1223 (7th Cir. 1998). Other courts too subscribe to this sentiment. See Koski v. Gainer, 1995 WL 599052, at *13 (N.D. Il. Oct. 5, 1995) ("Because naked statistical imbalances provide a 'treacherous rationale' for the implementation of race preferences, anecdotal evidence serves as useful corroboration.") (quoting Md. Troopers Ass'n v. Evans, 993 F.2d 1072, 1074, 1077 (4th Cir. 1993)); In re Chi. Police Officer Promotions, 1994 WL 424146 , at ${ }^{*} 12-13$ (N.D. Ill. Aug. 11, 1994) (" $[A] n$ inference of discrimination was not warranted solely on the basis of statistical disparities. Rather, some showing of causation was required."; "Where ... the bare statistical imbalance could have been caused by a number of factors other than race, the City was not justified in its rush to impose race-conscious relief without any attempt to link the disparities to discrimination."); N. State Law Enforcenent Officers Ass'n v. Charlotte-Mecklenburg Police Dep't, 862 F. Supp. 1445, 1457 (W.D.N.C. 1994) ("'Inferring past discrimination from statistics alone assumes the nost dubious of conclusions: that the true ineasure of racial equality is always to be found in numeric proportionality. The Fourteenth Amendment does not embody that view."') (quoting Md. Troopers, 993 F.2d at 1077); Bertoncini v. City of Providence, 767 F. Supp. 1194, 1202-03 (D.R.I. 1991) ("The City relies entirely on ... statistical disparity ... [that] provides hittle evidence of past discrimination by the Fire Department which is required under the Equal Protection Clause to justify 
Cases such as these are interesting for they illustrate the doctrinal confusion stemming from the federal courts' failure to carefully define its "strong basis in evidence" standard. Justice O'Connor's opinions in Wygant and Croson seem clear on the point that a statutory violation is unnecessary to establish a "strong basis in evidence"; such a standard, it is feared, would deter employers from voluntarily meeting their civil rights obligations. ${ }^{137}$ Justice O'Connor's determination that discrimination must only "approach[] a prima facie ... statutory violation" is consistent with this policy concern. The Court has emphasized both that a prima facie case is not equivalent to a formal finding of discrimination-it merely raises a rebuttable inference of discrimination ${ }^{138}$-and that the establishment of such a prima facie case is meant to be "minimal"139 or "not onerous."140 Decisions such as Maryland Troopers and Lalla are arguably inconsistent both with Justice O'Connor's policy concern and with the Court's determination that a prima facie statutory violation need only establish an inference of discrimination. By rejecting the possibility of grounding a "strong basis in evidence" solely in statistics, these decisions seem to require actual findings of intentional discrimination, evidential findings that resemble a full fledged statutory violation much more than a mere prima facie inference. Because the federal judiciary has failed to define carefully the "strong basis in evidence" requirement, however, federal affirmative action doctrine remains malleable, subject to the varied interpretations of liberal and conservative courts alike.

\section{Which Population is "Relevant" When Measuring Statistical Disparity?}

This Section considers how "relevant" populations are ascertained for the purpose of making statistical comparisons of disparity with an employer's workforce. The previously quoted Sixth Circuit standard highlights the attendant issues: the "minority percentage in the relevant statistical pool" is compared to the workplace's minority percentage, and the "relevant statistical pool is comprised of all persons qualifled for the position at issue."141 The key word here is "qualified." To illustrate, consider the following hypothetical. Suppose we sought to measure the statistical disparity of minorities in the town fire department. For acceptance as an entry level firefighter, there are several "qualifications": being at least eighteen years of age; passing a physical test, medical exam, and personal

the use of racial or ethnic classifications."; "[T] that suggests past discrimination by the Fire Department.").

137. E.g., supra note 89 and accompanying text.

138. See Int'I Bhd. of Teamsters v. United States, 431 U.S. 324, 336 (1977).

139. St. Mary's Honor Center v. Hicks, 509 U.S. 502, 506 (1993).

140. Texas Dep't of Community Affairs v. Burdine, 450 U.S. 248, 253 (1981).

141. United Black Firefighters Ass'n v. City of Akron, 976 F.2d 999, 1011 (6th Cir. 1992). 
interview; and having a minimum of $20 / 40$ eyesight. For promotion to lieutenant, the "qualification" is scoring $\mathrm{m}$ the top percentile on an exam given only to sergeants. From this simple lypothetical, three difficult issues regarding the "relevant" population emerge. First, when dealing with jobs suclı as entry-level firefighters, must the "relevant" comparative population already possess the qualifications, or can the population be everyone in the appropriate age group (on the theory that anyone in this group could acquire the requisite qualifications if they so desired)? Second, what happens when there is no statistical data quantifying the local population along the lines warranted by a particular job's qualifications? Finally, when dealing witl promotional positions (such as the fire department's lieutenant position), where the "qualification" de facto excludes those outside the employer's lower ranks, must the "relevant" population be likewise limited?

The first question arises most often in the context of entry-level positions where the qualifications are fairly basic. We liave seen what the Supreme Court has said on this inatter: skilled positions inust be distinguished from unskilled positions. The former requires a narrowly defined comparative labor pool while the latter allows comparison to the whole local labor market. Whereas truck drivers are considered "unskilled" because the skill involved "is one that many persons possess or can readily acquire," and positions for a job training program are "unskilled" because the program itself is "designed to provide expertise," teachers are "skilled" because their profession requires special training and expertise. ${ }^{142}$ This distinction, however, soinewhat begs the question in that it is unclear exactly where the potential for acquiring the skills at issue becoines strong enough to warrant the "unskilled" label. For this reason, at least one court has lamented the Supreme Court's "limited guidance in distinguishing skilled positions froin unskilled."143 It slould come as no surprise then that lower courts differ in tlieir definitions of "relevant" populations. While most courts simply employ the skilled-unskilled distinction in assessimg the job at issue, ${ }^{144}$ others have reframed this imquiry by also looking to the racial

142. See supra note 103.

143. Peightal v. Metro. Dade County (Peightal $h$ ), 940 F.2d 1394, 1404 (11th Cir. 1991).

144. For example, courts have diverged over whether entry-level firefighters require "special expertise." Some courts have found that no such expertise is required. See Peightal v. Metro. Dade County (Peightal II), 26 F.3d 1545 (11th Cir. 1994); Peightal I, 940 F.2d 1394; Davis v. City \& County of San Francisco, 890 F.2d 1438 (9th Cir. 1989); Bennett v. Arrington, 806 F. Supp. 926 (N.D. Ala. 1992), aff'd in part and rev'd in part sub nom. In re Birmingham Reverse Discrimination Employment Litig, 20 F.3d 1525 (11th Cir. 1994); Lalla v. City of New Orleans, 1999 WL 138900 (E.D. La. Mar. 12, 1999). Other courts have found that special expertise is required. See Hammon v. Barry 826 F.2d 73 (D.C. Cir. 1987); Janowiak v. Corporate City of South Bend, 836 F.2d 1034 (7th Cir. 1987). For cases demanding differentiated statistical comparisons when evaluating disparity in entry-level police department hiring, see Long v. City of Saginaw, 911 F.2d 1192 (6th Cir. 1990); Koski v. Gainer, 1995 WL 599052 (N.D. Ill. Oct. 5, 1995). 
makeup of job applicants (versus those who were hired) for statistical comparison. ${ }^{145}$

The second question addresses a particularly thorny issue for employers, that is, what happens when differentiated statistics exactly tracking the qualifications at issue simply do not exist? While it is clear that amorphous hunches of discrimination are insufficient to establish remedial need, how much leeway do employers have to implement voluntary race-conscious hiring and promotions plans im the absence of statistical precision? Like almost every other element of affirmative action jurisprudence, lower courts too are conflicted on this issue. On the deferential side of the judicial spectrum, we see cases like Aiken v. City of Memphis. ${ }^{146}$ There the Sixth Circuit was presented with a race-conscious promotions plan in the City's police and fire departments. To establish remedial need, the City presented statistics comparing the number of minorities among the ranks of lower level police officers and firefighters to minority representation in the higher ranks. While the court acknowledged the argument that this comparison was "overbroad" "since not all patrol officers and fire privates are qualified for promotion to the next rank," it nonetheless held "that the statistics presented here are probative enough to satisfy the City's burden of producing strong evidence that discrimination occurred in the Memphis Police and Fire Departments. ${ }^{.147}$

145. This trend represents a rather conservative understanding of the "relevant" population. Concededly, the Supreme Court has indicated that applicant data is relevant to this consideration. See Hazelwood Sch. Dist. v. United States, 433 U.S. 299, 308 n.13 (1977) (finding that applicant data is "very relevant" to the process of defining the "relevant" labor market). While it is unclear whether the Court ever intended applicant-flow data to be the sole consideration, some courts have gravitated to this form of measurement. See Anderson v. Douglas \& Lomason Co., 26 F.3d 1277, 1287 (5th Cir. 1994) (finding that "[a]ctual applicant flow figures are the preferred method by which to measure an employer's hiring practice and performance"); Vogel v. City of Cincinnati, 959 F.2d 594, 600 (6th Cir. 1992) (commending the City for not simply relying "on statistical comparisons with the general workforce of the City of Cincinnati," but rather for comparing "the composition of its police force with the applicant pool from which it was selected"); Ashton v. City of Memphis, 49 F. Supp. 2d 1051, 1069 (W.D. Tenn. 1999) (finding that the "relevant labor market should be defined as the number of applicants who were actually qualified for the job"); Lalla, 1999 WL 138900, at *4 (faulting the City for not presenting "any evidence regarding the number of blacks who have applied for the position of 'flre recruit' over the years"). The efficacy of this comparative method becomes particularly acute in the context of promotions where, by definition, the only qualified people are those who are applying.

146. 37 F.3d 1155 (6th Cir. 1994). See also Shuford v. Ala. State Bd. of Educ., 846 F. Supp. 1511, 1526 (M.D. Ala. 1994) (holding that despite a failure to provide differentiated statistics, this failure is excusable since "there is no available evidence from which it could establish the percentage of AfricanAmericans in the Alabama workforee who were 'qualified' to be employed in the covered positions," and finding that it would be both "illogical" and "unfair that Croson could be used as a shield behind which a defendant who had engaged in an unlawful discriminatory practice could be relieved, because of the nature of the discriminatory practice, of having to provide full and effective relief').

147. Aiken, 37 F.3d at 1163 . 
At the other end of the spectrum are cases such as Long v. City of Saginaw. ${ }^{143}$ In Long, the court was presented with evidence of statistical disparity comparing the total number of minorities im the City police force with the total number of minorities in the City's "protective services," a category which included such jobs as bouncers, lifeguards, correctional officers, and so on. Confronted with the argument that "minority availability in protective service was $29 \%$ as compared to a $7.7 \%$ minority representation in the Saginaw Police Department,"149 the court held that this comparison "failed to disclose the constant age, educational background, general physical fitness, and capabilities of its members and other material factors which would have afforded a basis from which meaningful statistical comparisons ... could have been fixed"; ;150 as such, the "protective services" statistics were "without probative value."151 While this holding is just as reasonable as Aiken in hight of Croson, these cases exude very different attitudes regarding the relative burden placed upon those defending affirmative action programs.

The third question is one that has not received much explicit judicial attention. It asks whether, in the context of race-conscious proinotion schemes, the "relevant" comparative population can extend beyond the employer's lower ranks (on the theory that those ranks too are infected by discrimination)? To illustrate this problem, consider again the facts of Boston Police. ${ }^{152}$ There, the court allowed the Boston Police Department to affirmatively promote an African-American to lieutenant through its affirmative action program, not because there was disparity in the aggregate number of minority sergeants compared to the percentage of sucli sergeants proinoted to lieutenant, but rather because "discrimination in promotions to sergeant reduced the pool of blacks ehgible to compete for promotions to lieutenant," thus making the promotion at issue a proper remedial measure. ${ }^{153}$ By and large, courts presented with similar facts have proved willing to expand the "relevant" population so that discrimination affecting the lower ranks is taken into consideration..$^{154}$ Some courts, however, have expressed discoinfort with this approach, fearing that such counterfactual assumptions, about the number of promotions that would have occurred had the entry-level positions been free of discrimination, are

148. 911 F.2d 1192 (6th Cir. 1990). See also Koski, 1995 WL 599052, at *14 (finding that there are "numerous affirmative and disqualifying employment requirements of the [Illinois State Police] (e.g., no visible tattoos, no felony convictions, good eyesight) show[mg] that not all persons in an exclusive age-range will measure up"; as such, it was for the jury to decide whether the statistics presented were sufficiently differentiated).

149. Long, 911 F.2d at 1199.

150. Id.

151. Id. at 1200 .

152. Boston Police Superior Officers Ass'n v. City of Boston, 147 F.3d 13 (1st Cir. 1998).

153. Id. at 20.

154. See supra Part II.B.3. 
far too speculative. The court in Middleton v. City of Flint, Michigan, for example, flatly declared: "[T]here is only one population group that is eligible for promotion to the rank of ... police sergeant. That relevant statistical pool is the population of previously hired ... police officers." 155 While statistics theoretically can expand the "relevant" comparative population to include entry-level officers excluded by discrimination, and then predict how many of those minority officers would have been promoted, the Sixth Circuit rejects such findings as "misleading because they are based on conclusory assumptions that have no basis in the law."156

The foregoing review yields three conclusions. First, substantial doctrinal confusion permeates the lower federal courts' efforts to define those remedial interests that satisfy the first prong of strict scrutiny review. Such confusion is most pronounced in the context of determining how much discrimination must be shown before a "strong basis in evidence" has been provided; while some courts have adopted a rather deferential attitude, allowing an employer to establish remedial need upon a showing of discrimination that only "approaches" a statutory violation, other courts have engaged in much more exacting review. Part of this inconsistency stems from the uncertainty surrounding exactly what constitutes a prima facie statutory violation in the first place. This confusion is only exacerbated when the technical questions arise concerning how workplace disparity should be measured: What sort of evidence is necessary to establislı remedial need? Can statistical showings of disparity ever stand alone, or must they be "corroborated" by anecdotal and historical evidence? Against what population should the workplace be measured to determine such disparity? Does the "relevant" population differ in the hiring and promotion contexts? These questions, and others like them, have generated varied federal court answers, and it is unlikely that supervening principles will emerge anytime soon.

Second, amidst all this confusion, a very different picture of affirmative action emerges than the one told by the dominant narrative. While courts diverge substantially when it comes to ascertaming "compelling" remedial need, it is underiable that many have deinonstrated strong resolve in keeping race-conscious remedies alive and well in the federal judiciary. Some courts have allowed remedial need to be evidenced by the present effects of long past discrimination. Despite ambiguity in Croson that could easily have been construed to require (at minimum) evidence of a prima facie statutory violation, some courts have used Justice O'Connor's "approaching a prima facie statutory violation" language to justify lesser showings of discrimination. Despite the unsettled legal context of Title VII, where it is unclear how dispositive of discrimination are statistics alone,

155. 92 F.3d 396, 407 (6th Cir. 1996).

156. Id. at 408 . 
some courts have allowed "naked statistics" to establish remedial need. Despite uncertainty about exactly who constitutes the "relevant" labor pool, some courts have both permitted undifferentiated statistics for jobs requiring (at least) some qualifications. While none of this per se "disproves" the dominant narrative, it does suggest that federal affirmative action jurisprudence is more complicated, and less conservative, than the pervading interpretation might have us believe.

Fimally, despite the threads of liberalism seen above, it is important to recognize that just as the dominant narrative should not report the demise of affirmative action based upon a few conservative decisions, so too is it mappropriate to cast federal jurisprudence in an unduly liberal light. Several courts have taken affirmative action's doctrinal ambiguity in conservative directions. Despite the seeming inapplicability of strict discriminatory purpose analysis in the prima facie statutory context, several courts have characterized "mere" showings of statistical disparity as a "dubious," "treacherous," and "deficien[t]" rationale for racial classifications. Despite the Supreme Court mandate that courts compare the "relevant" local population to workplace minority representation, several courts have defined "relevant" in very conservative ways, considering only those minorities that applied to the employer rather than all qualified minorities in the local labor pool. An appreciation of these conservative, as well as liberal, developments facilitates a more nuanced understanding of the last decade's federal affirmative action jurisprudence, an understanding that represents a first step toward retelling the prevailing narrative.

\section{III}

\section{The Constitutionality of Affirmative Action: Narrow Tailoring}

This Cominent's effort to retell the narrative of affirmative action continues by examining how lower federal courts have interpreted the second prong of strict scrutiny in the workplace affirmative action context; that is, what does it mean for a race-conscious hiring, firing, or promotion plan to be "narrowly tailored"? Like the courts' inquiry imto "compelling" remedial interests, the black letter standard for narrow tailoring is fairly clear. Focus is typically placed on (1) the necessity of race-conscious relief, (2) the fiexibility, (3) duration, and (4) extent of such relief, and (5) the remedial program's impact on third party rights. Also like the "strong basis in evidence" requirement, however, these seemingly clear doctrinal considerations become complicated in their application.

\section{A. Setting the Stage: Supreme Court Pronouncements in Paradise and Croson}

It is useful to begin by examining what the Supreme Court has said on the topic of narrow tailoring. As in other areas of affirmative action, the 
Court has not provided a very clear framework for determining exactly where the burdens imposed by preferential race-conscious programs become too great for the Constitution to bear. ${ }^{157}$ This is not to say that guidance has been wholly lacking; in fact, the Court has outlined several factors that should guide the narrow tailoring inquiry. For such judicial direction, consider the Court's holdings in United States v. Paradise ${ }^{158}$ and City of Richmond v. J.A. Croson. ${ }^{159}$

\section{United States v. Paradise}

By 1972, the Alabama Department of Public Safety had, for almost forty years, systematically discriminated against minorities through its hiring and promotion policies. After two failed efforts to encourage the promotion of minorities into the Department's upper ranks, the District Court imposed an affirmative action program mandating that at least " $50 \%$ of the promotions to corporal inust be awarded to black troopers, if qualified black candidates were available."160 Similarly, for all other upper ranks, the District Court "imposed a 50\% proinotional quota . . ., but only if there were qualified black candidates, if the rank were less than $25 \%$ black, and if the Department had not ... implemented a promotion plan without adverse impact for the relevant rank."161 Upon implementation of this onefor-one promotional plan, eight whites and eight blacks were promoted to corporal. While the District Court subsequently suspended the fifty percent requirement, the United States challenged the one-for-one remedial plan on the ground that it violated the Equal Protection Clause.

In a plurality decision, Justice Brennan rejected this challenge. Applying strict scrutiny, ${ }^{162}$ he noted the obvious remedial purpose: "[T]he pervasive, systemic, and obstinate discriminatory conduct of the Department created a profound need and a firm justification for the race-conscious relief ordered by the District Court." 163 Froin there, Justice

157. E.g., ROSENFELD, supra note 78, at 215 (finding that while affirmative action plans inevitably impose burdens, the question becomes "whether the difference in burden between preferential layoffs, hiring, and promotions and their respective race-neutral ... counterparts is constitutionally tolerable. And on this ... . issue the Court provides very little guidance").

158. 480 U.S. 149 (1987).

159. 488 U.S. 469 (1989).

160. Paradise, 480 U.S. at 163

161. Id.

162. Note that as of 1987 , no Court majority, let alone Justice Brennan, had settled upon strict scrutiny as the appropriate standard of review in these "reverse discrimination" cases. Justice Brennan employed such scrutiny because he believed that the promotion plan survived elevated review and there was no reason to engage the intermediate versus strict scrutiny debate. Consequently, even under today's Croson-inspired regime, the narrow-tailoring framework explicated by Justice Brennan continues to guide lower courts. That being said, since the dissenting Justice ( $O$ 'Connor) now controls the Court's affirmative action jurisprudence, it is likely that while Justice Brennan's doctrinal framework persists, the liberal spirit animating that framework does not.

163. Paradise, 480 U.S. at 167. 
Brennan turned to the critical question of narrow tailoring. In so doing, he examined four factors: (1) the relief's necessity and possible alternatives; (2) the relief's flexibility and duration; (3) the reasonableness of the relief's numerical goals; and (4) the rehef's impact on innocent third parties. ${ }^{164}$ Due to the pervasive history of discrimination and the likelihood of its continuation, Justice Brennan determined that it was doubtful "that the [1983] District Court had available to it any other effective remedy"" than the fifty percent quota. ${ }^{165}$ Because the one-for-one requirement applied only if there were "qualified candidates" and because the policy was tenporary, Justice Brennan insisted that "the remedy chosen has proved both effective and flexible." 166 The numerical quota of fifty percent was accepted because of the long delays that had characterized the Department's racial integration up until that point; simply put, "the figure

164. Id. at 171 .

165. Id. at 177 (quoting Local 28 of the Sheet Metal Workers Int'l Ass'n v. EEOC, 478 U.S. 421 , 486 (1986) (Powell, J., concurring in part and concurring in judgment)). This notion of "effective" altematives will come up later, and thus it is worth pausing on Justice Brennan's analysis. The Government argued that since the trial judge could have imposed fines, rather than a race-conscious promotions plan, the plan was not narrowly tailored. Justice Brennan responded, in part, by emphasizing the immediate need for relief: "[I]mposing fines on the defendant does nothing to compensate the plaintiffs for the long delays in implementing acceptable promotion procedures." Id. at 175. Furthermore, "[f]ining the defendant lacks even the lone virtue of the Department's proposal to promote four blacks: that at least a step would be taken toward the eradication of past discrimination by elevating blacks in the hierarchy." Id. at $175 \mathrm{n} .25$.

166. Id. at 179. In the Court's discussion of flexibility, it made reference to the previous term's Sheet Metal Workers decision. While this case dcalt primarily with Title VII, and only briefly with a constitutional challenge, it still merits brief mention, for it further illustrates affirmative action's contentious doctrinal framework. At issue were numerical employment goals as a remedy for persistent and egregious discrimination. Specifically, a district court found New York City's Local 28 guilty of "discriminating against nonwhites in recruitunent, selection, training, and admission to the union." Sheet Metal Workers, 478 U.S. at 429 . Because the union had stubbornly resisted previous attempts of judicially imposed affirmative action, the district court "established a $29 \%$ nonwhite membership goal, based on the percentage of nonwhites in the relevant labor pool in New York City, for the union to achieve by July 1,1981 ." Id. at 432 . Claiming that the district court only had the power to remedially compensate "the actual victims of unlawful discrimination," the union petitioned the Court to vacate judgment. Id. at 444. Writing for the plurality, Justice Brennan declared that the district court requirement was both statutorily and constitutionally permissible. Id. at 475-81. While Justice Brennan cautioned that affirmative action should only be used in rare and necessary circunistances, since this case involved a temporary district court order that sought to remedy the effects of "pervasive and egregious" discrimination, Justice Brennan concluded that this was such a necessary case. Id. at 476-77. In dissent, Justice O'Connor accused Justice Brennan of lacking "comınon sense" in his interpretation of Title VII's legislative history. Id. at 492 (O'Counor, J., dissenting). To her, Congress's clear intent was to ban racial quotas. Id. at 495-97. While she agreed with the plurality that racial goals could be ordered to remedy past discrimination, she insisted that "the use of a rigid quota turns a sensible rule of thumb into an unjustified conclusion about the precise extent to which past discrimination has lingering effects." Id. at 494. Similarly, Justice Powell rejected the plurality's allowance of quotas. Id. at 487. Unlike Justice O'Connor, however, Justice Powell intimated that even "goals" would be unconstitutional unless they were shown to benefit the actual victims of discrimination. Id. Finally, Justice Rehnquist's dissent made Justice Powell's intimation exphicit; to him, Title VII "forbids a court to order racial preferences that effectively displace nonminorities except to minority individuals who have been the actual victims of a particular einployer's racial discrimination." Id. at 500 . 
selected to compensate for past discrimination and delay necessarily involved a delicate calibration of the rights ... of the plaintiff class, the Department, and the white troopers."167 Finally, Justice Brennan concluded that the temporary one-for-one requirement did not unduly burden non-minorities, at worst, it merely postponed their ultimate promotion. ${ }^{168}$

On its face, the Paradise opinion offers lower courts a useful framework for conducting narrowly tailored analysis. These doctrinal guides, however, suffer from substantial ambiguity in practice. While Paradise tells us that governmental units generally must consider race-neutral alternatives before adopting affirmative action plans, at what point can the search for alternatives end and the implementation of race-conscious measures begin? While Paradise tells us that "flexibility" and "duration" must be considered, is there a meaningful difference between racial "goals" and racial "quotas"? ${ }^{169}$ If so, how strict can these inore flexible goals be? While Paradise tells us that there must be a reasonable relationship between the numerical goals and relevant labor market, how strict inust that relationship be? For example, when seeking to accelerate relief, how much freedom does an affirmative action plan have to impose a higher minority percentage than that found in the relevant labor inarket? Finally, while Paradise considers the harm to third parties, exactly where should we draw the line between "acceptable" and "unacceptable" harms?"

167. Paradise, 480 U.S. at 181-82.

168. Id. at 182-83. Because of the Court's changing composition, it is worthwhile to sketch briefly Justice O'Connor's dissenting opinion in Paradise. Her dissent, joined by Justices Rehnquist and Scalia, accused the plurality of misusing the standard of strict scrutiny. Id. at 196-97 (O'Connor, J., dissenting). While Justice O'Connor agreed that a compelling state interest existed, she disputed the plurality's contention that the Department policy was narrowly tailored. Id. The dissent first argued that the one-for-one policy was not "manifestly necessary" to eradicate the Department's delay of integration; since the promotion plan stopped once the Department developed a promotion plan that did not adversely affect blacks, and did not continue until the $25 \%$ black representation goal had been reached, Justice O'Connor doubted the program's remedial goal. Id. at 197-98. Second, Justice O'Connor disagreed with the efficacy of using a $50 \%$ hiring goal to achieve $25 \%$ black representation. "Such a justification ... necessarily eviscerates any notion of 'narrowly tailored' because it has no stopping point; even a $100 \%$ quota could be defended on the ground that it merely 'determined how quickly the Department progressed toward' some ultimate goal." Id, at 199. Finally, Justice O'Connor insisted that "the District Court had available several alternatives that would have achieved full compliance with the consent decrees without trammeling on the rights of nonminority troopers." Id. at 199-200. These alternatives included appointment of a trustee to oversee promotion procedures, employment of stiff fines and penalties until the Department complied, and the use of nonracial criteria when enforemg the integration requirement. $I d$. at 200 . Failure to appreciate these alternatives, Justice O'Connor insisted, turned "narrow tailoring" on its head: "If a District Court order that is imposed after no evident consideration of the available alternatives can survive strict scrutiny as narrowly tailored, the requirement that a racial classification be 'narrowly tailored' for a compelling governmental purpose has lost most of its meaning." Id. at $20 \mathrm{I}$.

169. See, e.g., Robert K. Fullinwider, The Reverse Discrimination Controversy 162-64 (1980) (arguing that it is mislcading to posit a shurp difference between quotas and goals).

170. For example, Paradise left unresolved a question that has persisted since Wygant; that is, can affirmative action layoff provisions ever survive narrow tailoring analysis? In Wygant, Justice Powell 
questions, and others like them, reveal that Paradise left much unresolved m its wake.

\section{City of Richmond v. J.A. Croson}

While Justice O'Connor's Croson opinion ${ }^{171}$ only briefly considered the question of narrow tailoring, it illustrates the foregoing ambiguity and suggests that some of Justice Brennan's broad propositions in Paradise have been undermined. ${ }^{172}$ First, Justice O'Connor found that Richmond had not considered race-neutral alternatives before inplementing its minority set-aside program: "If [Minority Business Enterprises] disproportionately lack capital or cannot ineet bonding requirements, a race-neutral program of city financing for sinall firms would, a fortiori, lead to greater minority participation."173 Since Richmond had a "whole array of race-neutral devices"174 theoretically ${ }^{175}$ available to rectify shortfalls in public minority

found such layoff provisions substantively different from hiring and promotions provisions, and thus particularly susceptible to narrow tailoring challenges:

While hiring goals impose a diffuse burden, often foreclosing only one of several opportunities, layoffs impose the entire burden on achieving racial equality on particular individuals, often resulting in serious disruption of their lives. That burden is too intrusive.... Other, less intrusive means of accomplishing similar purposes-such as the adoption of hiring goals-are available. For these reasons, the Board's selection of layoffs as the means to accomplish even a valid purpose cannot satisfy the demands of the Equal Protection Clause.

Wygant v. Jackson Bd. of Educ., 476 U.S. 267, 283-84 (1986). In a concurring Wygant opinion, however, Justice $O$ 'Connor argued that the "troubling questions whether any layoff provision could survive strict scrutiny" should be left to another day. Id. at 293. In Paradise, Justice Brennan simply contrasted the instant hiring goals with the more burdensome layoff provision without resolving the per se acceptability of layoff provisions. See Paradise, 480 U.S. at 182-83.

171. For a description of the facts and holding of the case, see Part II.A.2.

172. This makes sense simce it was Justice O'Connor who wrote the primary dissent in Paradise. Supra note 168, at 196.

173. City of Richmond v. J.A. Croson, 488 U.S. 469, 507 (1989).

174. Justice O'Connor outlined the following possibilities:

Simplification of bidding procedures, relaxation of bonding requirements, and training and financial aid for disadvantaged entrepreneurs of all races would open the public contracting market to all those who have suffered the effects of past societal discrinimation or neglect. Many of the fornal barriers to new entrants may be the product of bureaucratic inertia more than actual necessity, and inay have a disproportionate effect on the opportunities open to new minority firms. Their elimination or modificaticn would have little detriniental effect on the city's interests and would serve to incrcase the opportunities available to nincrity business without classifying nidividuals on the basis of race. The city may also act to prohibit discrimination in the provision of credit or bonding by local suppliers and banks. Business as usual should not inean business pursuant to the unthinking exclusion of certain members of our society froin its rewards.

Id. at 509-10.

175. I say "theoretically" because nowhere does the Court investigate the practical efficacy of these asserted "alteruatives." Instead the Court assumes that since there is no record that Richmond considered these options, they will be considered viable until proven otherwise. In this way, the burden is shifted to the city to denonstrate the impracticality of these posited race-neutral options. Interestingly, Justice O'Connor quotes Justice Powell's concurrence in Fullilove v. Klutznick. "[B]y the time Congress enacted [the MBE set-aside] in 1977, it knew that other remedies had failed to ameliorate the effects of racial discrimination in the construction industry." Id. at 597 (quoting 
contracting awards, the city's race-conscious program was not narrowly tailored. Second, Justice O'Connor found Richmond's 30 percent minority "quota" too inflexible. Initially, she observed that the 30 percent objective "rests upon the 'completely unrealistic' assumption that minorities will choose a particular trade $\mathrm{m}$ lockstep proportion to their representation im the local population."176 Then, Justice O'Connor examined the waiver provision in Richmond's plan, ultimately finding it too rigid - whereas previous case law had allowed waivers where an MBEs higher price was "not attributable to the effects of past discrimination,"177 Richmond's "waiver system focuses solely on the availability of MBEs; there is no mquiry into whether or not the particular MBE seeking a racial preference has suffered from the effects of past discrimination by the city or prime contractors."178

Given Justice O'Connor's observations in Croson, three tentative conclusions are warranted. First, the inquiry imto race-neutral alternatives is a relatively demanding one. Before implementing race-conscious affirmative action plans, the governmental entity must demonstrate that some attention has been paid to possible alternatives. It is unclear from Croson, however, how far this requirement should be pushed. After all, if the standard truly is that all theoretical alternatives must be ruled out, it is difficult to imagine any race-conscious program passing strict scrutiny. Second, while "goals" tend to be favored over "quotas," the line dividing the two is ill-defined. Ultimately, the goal/quota distinction seems to turn on the adequacy of waiver provisions; the more flexible the waiver, and the more it is tied to showings of particularized discrimination, the more likely the plan will avoid the "quota" designation. Finally, while Paradise allowed inflated numerical set-aside percentages to facilitate remediation, Croson backed away from this liberal standard requiring instead a tighter fit between numerical goals and the relevant labor population. It remains to be seen, however, if any vestiges of the Paradise approach remain. To investigate how these ambiguities, and those found in Paradise, play out in the lower federal courts, let us now turn to that jurisprudence.

Fullilove, 448 U.S. 448, 511 (1980) (Powell, J., concurring)). This characterization of Fullilove, however, reveals the Court's increasing conservatism on the altematives question. In Fullilove, Congress and the Executive had simply observed that despite years of race-neutral anti-discrimination law, minority contractors nationwide still received less than $1 \%$ of federal contracts; nowhere (as in Croson) was there an outline of the prospective actions that could be taken to solve the problem. Fullilove, 448 U.S. at 511.

176. Croson, 488 U.S. at 507 (quoting Local 28 of the Sheet Metal Workers Int'l Ass'n v. EEOC, 478 U.S. 421, 494 (1986) (O'Connor, J., concurring in part and dissenting in part)). Notably absent froin this consideration, however, was Justice Brennan's willingness in Paradise to allow inflated setaside percentages to accelerate remedial success. See supra note 166 and accoinpanying text.

177. Fullilove, 448 U.S. at 488.

178. Croson, 480 U.S. at 508. 


\section{B. Defining "Narrowly Tailored" in the Lower Federal Courts"}

\section{The Necessity of Relief and the Efficacy of Alternative Remedies}

When courts consider affirmative action plans under this first prong of the Paradise framework, their analysis proceeds in at least one of two related directions. Initially, courts examine whether the races benefited by the affirmative action plan have suffered identifiable discrimination. For all practical purposes, this analysis tracks the "substantial basis in evidence" inquiry: if a compelling remedial interest has been found, the relief is considered necessary, ${ }^{180}$ if no such interest is found, then a lack of necessity is briefly noted. ${ }^{181}$

The second, and most significant, consideration of courts assessing the "necessity" of affirmative action involves the efficacy of race-neutral alternatives. We have seen from Paradise and Croson that the Court has given only limited (and at times conflicting) gnidance on this point. It should not be surprising, therefore, that the lower courts too are conflicted over exactly how carefully einployers must consider alternatives before impleinenting race-conscious relief. In practice, courts have approached this issue in one of four ways: (1) some implicitly adopt a per se rule that the record must at least evidence soine effort by the government actor to consider race-neutral alternatives before adopting a race-conscious remedial program-failure to do so renders the program insufficiently

179. As we will see in this following section, inost lower federal courts organize their narrowtailoring analysis according to the four-factor Paradise framework. Consequently, this section employs the same organizational scheme.

180. See Edwards v. City of Houston, 37 F.3d 1097, 1113 (5th Cir. 1994); Howard v. McLucas, 871 F.2d 1000, 1008 (11th Cir. 1989); Allen v. Ala. State Bd. of Educ., 976 F. Supp. 1410, 1430 (M.D. Ala. 1997), aff'd, 164 F.3d 1347 (11 th Cir. 1999); Sims v. Montgomery County Comm'n (Sims II), 887 F. Supp. 1479, 1488 (M.D. Ala. 1995); Shuford v. Ala. State Bd. of Educ., 846 F. Supp. 1511, 1528 (M.D. Ala. 1994); Houston Chapter of the Int'l Ass'n of Black Prof'l Firefighters v. City of Houston, 1991 WL 340296, at *33 (S.D. Tex. May 3, 1991).

181. See Middleton v. City of Flint, Michigan, 92 F.3d 396, 410 (6th Cir. 1996); Kane v. Freeman, 1997 U.S. Dist. LEXIS 4063, at *20 (M.D. Fla. Mar. 17, 1997). While this particular analysis is fairly elementary, two wrinkles should be noted. First, soine affirmative action plans explicitly benefit several races, but are able to marshal evidence of discrimination for only a subset of those races; in such situations, courts use this prong of narrow tailoring to trim race-conscious remedies to only those races evidencing remedial need. See Alexander v. Estepp, 95 F.3d 312, 316 (4th Cir. 1996); Edwards v. City of Houston, 37 F.3d 1097, 1113 (5th Cir. 1994). Second, at least two courts in the Fifth Circuit lave skipped the "substantial basis in evidence" analysis altogether and have simply asserted under this prong of narrow tailoring that the remedial programs at issue were not "necessary." Interestingly, both cases found statistical disparities (standing alone) insufficient to establish remedial need. See Dallas Fire Fighters Ass'n v. City of Dallas, Texas, 150 F.3d 438, 441 (5th Cir. 1998) (finding that despite statistical evidence of underrepresentation, "the record is devoid of proof of a history of egregious and pervasive discrimination or resistance to affirmative action that has warranted more serious measures in other eases"), cert. denied, 526 U.S. 1046 (1999); Dallas Fire Fighters Ass'n v. City of Dallas, Texas, 885 F. Supp. 915, 921 (N.D. Tex. 1995) (finding that "naked statistical imbalance" does not justify a race-conscious promotions plan). 
tailored; ${ }^{182}$ (2) some adopt a prospective results-based approach, where the efficacy of alternatives turns on the likely success or failure of raceneutral efforts that could be implemented to lessen disparity; ${ }^{183}$ (3) some adopt a historical results-based approach, where the efficacy of alternatives turns on the relative success or failure of prior race-neutral efforts to lessen disparity; ${ }^{184}$ and (4) some adopt a historical estoppel-based approach,

182. See Hayes v. N. State Law Enforcement Officers Ass'n, 10 F.3d 207, 216 (4th Cir. 1993); Freeman v. City of Fayetteville, 971 F. Supp. 971, 976 (E.D.N.C. 1997); Hiller v. County of Suffolk, 977 F. Supp. 202, 206 (E.D.N.Y. 1997); Kane, 1997 U.S. Dist. LEX1S 4063, at *21; N. State Law Enforcement Officers Ass'n v. Charlotte-Mecklenburg Police Dep't, 862 F. Supp. 1445, 1459 (W.D.N.C. 1994).

183. Some courts have upheld workplace affirmative action programs under this prospective approach. See Boston Police Superior Officers Ass'n v. City of Boston, 147 F.3d 13, 25 (1st Cir. 1998) (finding that "there is no suggestion that any race-neutral measure would have been adequate .... Race-neutral measures, such as education or recruitment, would not provide a timely remedy."); Officers for Justice v. Civil Serv. Comm'n, 979 F.2d 721, 727 (9th Cir. 1992) (approving a "banding" procedure, where promotion exam scores that fall within a statistically derived "band" are treated the same for measuring the skills, knowledge and abilities of those taking the exam, because it produced less disparity than the "strict rank ordering" alternative); Howard v. McLucas, 871 F.2d 1000, 1009 (11th Cir. 1989) (finding that purported alternatives "are not feasible because they do not place the plaintiffs in their rightful place or do not do so as expeditiously"); Chieago Fire Fighters Union, Local No. 2 v. City of Chicago, 1999 WL 1289125 , at *71 (N.D. I11. Dec. 30, 1999) (finding that the "only reasonable and rcalistic alternative the City had available to it to remedy the past intentional discrimination in the [Chicago Fire Department] was to make linited, non-rank order promotions pursuant to a policy of affirmative action"); Allen, 976 F. Supp. at 1430 (approving the use of an arguably race-conscious testing procedure because of expert testimony that "none of the off-the-shelf tests currentiy available would meet the p-value restrictions of the consent decree"), aff' $d, 164$ F.3d 1347 (11th Cir. 1999); Houston Chapter of the Int'l Ass'n of Black Prof'l Firefighters, 1991 WL 340296 , at *34 (finding alternatives to race-conscious action "not feasible because they do not place the plaintiffs in their rightful place or do not do so as expeditiously"). Other courts, however, have used this approach to find race-conscious programs inadequately tailored. See Alexander, 95 F.3d 312, 316 (invalidating a race-conscious fire department hiring plan on the basis that the department could have addressed the disparity by eliminating its "volunteer preference" selection criteria); In re Birmingham Reverse Discrimination Employment Litig., 20 F.3d 1525, 1547 (11th Cir. 1994) (invalidating a racebased promotions remedy because the city could simply have eliminated the addition of "seniority points" to promotion test scores, etnployed promotion exams without disparate impact, and/or considered race just as one factor among many); Krupa v. New Castle County, 732 F. Supp. 497, 517 (D. Del. 1990) (finding that the County could have adopted a plan where race was "only considered as a 'plus' in the sense of the Harvard type plan endorsed in Bakke"). For an example of this rather conservative approach in the housing context, see Walker $v$. City of Mesquite, Texas, 169 F.3d 973, 982-85 (5th Cir. 1999) (invalidating a district court order directing the construction of low-cost housing units in predominantly white neighborhoods on the theory that the alternative of Section 8 housing vouchers can effectively produce the same desegregation end).

184. Sone courts have used this approach to uphold affirmative action programs. See Peightal v. Metro. Dade County (Peightal II), 26 F.3d 1545, 1557-58 (11th Cir. 1994) (finding that the fire department "satisfactorily considered and implemented race-neutral means before deeming them ineffective and undertaking race-conscious measures" when the department "imitiated high school and college recruiting," "held outreach programs which minority firefighters spearheaded," and "designated a recruitment specialist to organize and implement a special recruitment program"); In re Birmingham, 20 F.3d at 1546 (finding that while there was evidence of discrimination before 1974, a five-fold increase in the number of African-American hiring rendered the affirmative action plan at issue unnecessary); Peightal v. Metro. Dade County (Peightal I), 940 F.2d 1394, 1407 (11th Cir. 1991) (finding that since the fire department conducted outreach and recruiting "without success," it had 
where employers are estopped from adopting race-conscious remedial programs if they previously had the opportunity to avoid disparity in race-neutral ways, but failed to do so. ${ }^{185}$

\section{The Flexibility and Duration of Relief}

When courts measure an affirmative action plan's "flexibility," judicial inquiry typically surrounds one of four related issues. The first three require only brief attention. Initially, courts often examine whether the contested affirmative action plan seeks to attain precise statistical parity with the relevant labor pool's minority representation; when courts suspect that this is the goal of a race-conscious policy, it is almost always invalidated. ${ }^{186}$ Second, some courts consider whether the affirmative action plan

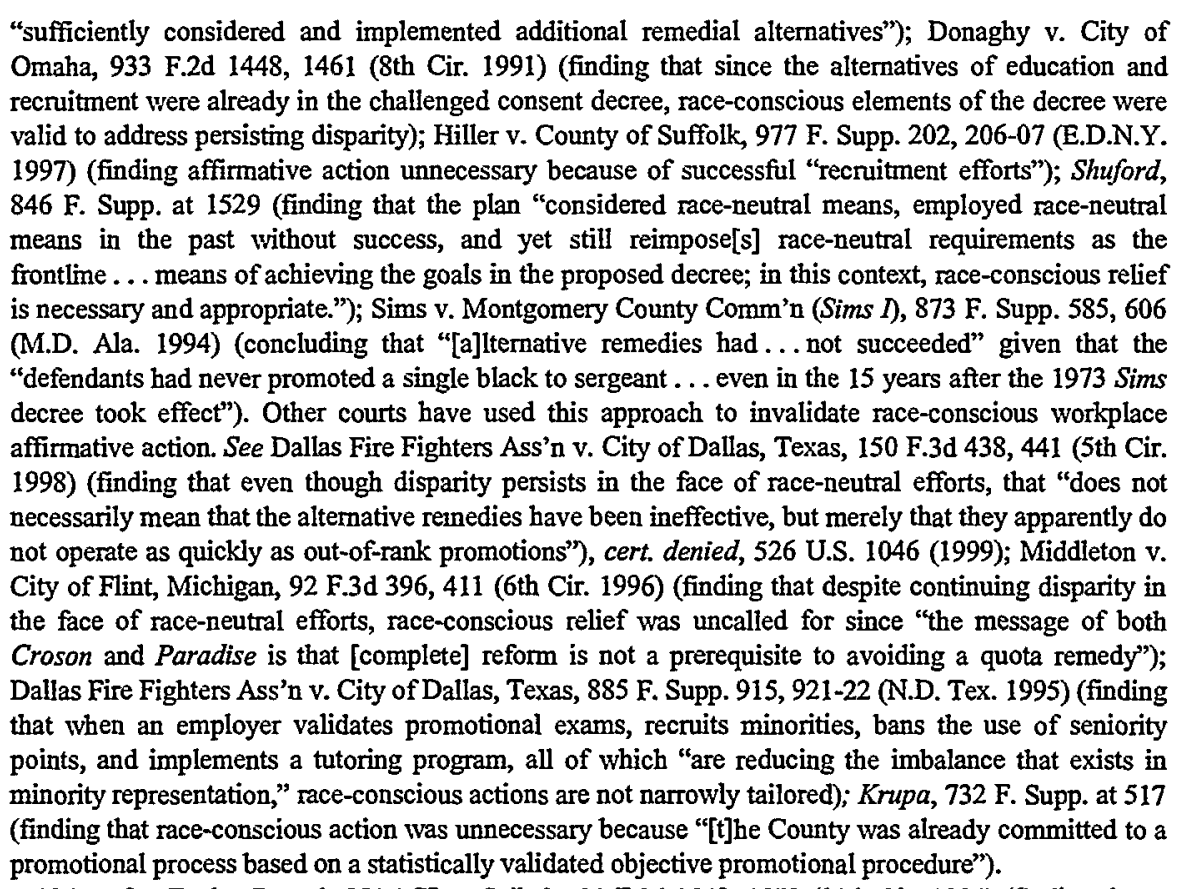
185. See Ensley Branch, NAACP v. Seibels, 31 F.3d 1548, 1572 (11th Cir. 1994) (finding that a government agency cannot continue to use racially discriminatory selection practices and then "attempt to cure the resulting mjury to blacks with race-conscious affirmative action" ); Billish v. City of Chicago, 989 F.2d 890, 894 (7th Cir. 1993) (finding that a city "cannot get poimts for first using a presumptively biased eligibility list to make a string of white promotions and then turning around and trying to do some rough racial justice by promoting two blacks from the bottom of the list"); Asliton v. City of Memplis, 49 F. Supp. 2d 1051, 1061 (W.D. Tenn. 1999) (finding that a city cannot knowingly use an unvalidated and disparity-producing promotions test and then use "affirmative action to adjust the order of promotions produced from the results of a non-valid test"); Koski v. Gainer, 1995 WL 599052, at *17 (N.D. Ill. Oct. 5, 1995) (finding that "courts have condemned the practice of hiding behind the discriminatory effects of a selection or promotion procedure while simultaneously manipulating racial percentages to remedy the resulting racial inequity").

186. In re Birmingham, 20 F.3d at 1548 (finding that a " $50 \%$ annual quota for promotions of blacks ... is designed to achieve the unconstitutional objective of outright racial balancing"); Howard, 
requires the employer to hire or promote unnecessarily. ${ }^{187}$ Third, at least one circuit has found that merely assigning a city the sole power to raceconsciously transfer officers in its police force violates the flexibility requirement of narrow tailoring. ${ }^{188}$

The fourth, and most substantial, factor guiding lower federal courts is the issue of qualifications. Generally speaking, if the challenged raceconscious program does not sacriflce employee qualiflcations, courts have been willing to find the program sufficiently "flexible." To determine whether a remedial program guarantees "qualifled" minority workers, four factors are often considered: (1) whether the affirmative action plan will require the hiring or promotion of unqualified minority workers; ${ }^{189}$ (2) whether hiring or promoting minority mdividuals over

871 F.2d at 1009 (defending challenged remedial plan on the basis that "the relief is not meant to set employment percentage goals or ensure a racially balanced workforce"); Ashton, 49 F. Supp. $2 \mathrm{~d}$ at 1066 (finding that "the longer a consent decree remains in effect, the more it appears" that the decree is being "used to achieve and maintain racial balance"); Freeman v. City of Fayetteville, 971 F. Supp. 971, 976 (E.D.N.C. 1997) (finding that "the specific percentage figures "cannot be said to be narrowly tailored to any goal, except perhaps outright racial balancing") (quoting City of Richmond v. J.A. Croson, 488 U.S. 469,507 (1989)); Kane, 1997 U.S. Dist. LEXIS 4063, at *23 (invalidating a racebased promotion plan because of its "fundamentally flawed" effort "to create parity between the racial composition of the labor pool and the race of employees in each rank position"); Koski, $1995 \mathrm{WL}$ 599052 , at *16 (invalidating a program that "undeniably maintained an ultimate goal of racial parity"); Houston Chapter of the Int'l Ass'n of Black Prof'l Firefighters, 1991 WL 340296, at *33 (defending challenged affirmative action plan on the basis that it "clearly is not designed to maintain a particular racial balance"). Contra Davis v. City \& County of San Francisco, 890 F.2d 1438, 1447 (9th Cir. 1989) (upholding a raee-conscious consent decree that "ordered the hiring of minorities and women im percentages equal to their representation in the labor market").

187. In re Birmingham, 20 F.3d at 1547 (finding that a factor in the affirmative action plan's favor is that "the City decree does not require unnecessary promotions in providing relief"); Howard, 871 F.2d at 1009 (noting with approval that "the government is not required to make a promotion unless one is necessary"); Ashton, 49 F. Supp. 2d at 1065 (finding sufficient fiexibility when the race-based promotions plan requires only "that the City ... use affirmative action to promote qualified black patrol officers when the City conducts a promotion process").

188. See Police Ass'n ex rel Cannatella v. City of New Orleans, 100 F.3d 1159, 1169 (5th Cir. 1996); Police Ass'n v. City of New Orleans, 1995 WL 31 1982, at *13 (E.D. La. May 18, 1995).

189. Some courts find sufficient flexibility when job qualifieations are required. See Edwards v. City of Houston, 37 F.3d 1097, 1114 (5th Cir. 1994) (finding that since the plan "requires only the remedial promotion of qualified blacks and hispanics [sic] [in that o]nly members of the plaintiff class who have passed the appropriate promotional exam are eligible for promotion . . . the police department is never required to promote an unqualified minority in preference of a qualified nonminority"); Peightal II, 26 F.3d at 1559 n.21; Peightal I, 940 F.2d at 1408 (finding (in both) a race-conscious hiring plan to be a goal, not a quota, because the plan allowed the employer to reject unqualified minority applicants); Howard, 871 F.2d at 1009 (finding that all minority promotions were sufficiently qualified); Chi. Fire Fighters Union, Local No. 2 v. City of Chicago, 1999 WL 1289125, at *72 (N.D. IIl. Dec. 30, 1999) (noting with approval that everyone promoted out of rank order "was qualified for the position"); Ashton, 49 F. Supp. 2d at 1063-65 (finding that a race-conscious pronotions plan withstood charges of inflexibility because it did not result in the promotion of unqualified police officers); Allen v. Ala. State Bd. of Educ., 976 F. Supp. 1410, 1431 (M.D. Ala. 1997) (finding that efforts to devise a disparate impact free hiring test would not result in "[1]ess qualified black individuals...be[ing] given preference over more qualified white individuals. Instead, the requirements of the test will be applied equally to cach candidate, irrespective of race."), aff d, 164 F.3d 1347 (11th Cir. 1999); Sims v. Montgomery County Comm'n (Sims II), 887 F. Supp. 1479, 1488 (M.D. 
better scoring white individuals results in a less qualified workplace; $;^{190}$ (3) whether sufficient waiver provisions have been built into the affirmative action plan; ${ }^{191}$ and (4) whether the impleinentation plan is, in fact, carried out in an flexible manner. ${ }^{192}$

When courts assess whether an affirmative action plan has appropriate "duration," judicial inquiry turns on whether the remedial program's projected term corresponds with the degree of remedial need. When programs

Ala. 1995) (finding the promotion of two blacks and two whites to be reasonably flexible because all were "equally qualified" and the promotion was a one-time measure); Sims I, 873 F. Supp. at 606 (finding that "[a]ll of the blacks who were promoted were considered qualified pursuant to the written examination and oral interviews given to all applicants for the 1988 promotions"). For a ease that has invalidated an affirmative action program on this basis, see Bertoncini v. City of Providence, 767 F. Supp. 1194, $1203-04$ (D.R.I. 1991) (finding that since "the City began with the premise that $20 \%$ of the applicants selected... would be minorities and/or women," and since "in setting that figure no restriction was placed on how far down the ranking list the City would go in order the achieve its goal," "the system of preference utilized bears some of the indicia of a quota or an infiexible adherence to a preordained numerical standard").

190. See Boston Police Superior Officers Ass'n v. City of Boston, 147 F.3d 13, 24 (1st Cir. 1998) (finding that "the one-point difference between [the African-American's] score and that of the white Plamtiffs was ... negligible" and that as a result the race-conscious "promotion did not unduly interfere with any valid [qualification] policies"); Officers for Justice v. Civil Serv. Comm'n, 979 F.2d 721, 72728 (9th Cir. 1992) (finding that test scores are "imprecise measurements of future job performance and that by banding the scores ... the City may increase the probability that the most qualified candidates will be promoted"); Jansen v. City of Cimcinnati, 977 F.2d 238, 243 (6th Cir. 1992) (validating a raceconscious hiring program, which hired African Americans scoring lower than Whites on the entrance exam, (in part) because "there is no indication that ... fire personnel, who score higher on the exam, perform better on the job. The test merely ensures ... that cach fire recruit is "qualified"'); Vogel v. City of Cincinnati, 959 F.2d 594, 599 (6th Cir. 1992) (seeing merit im the fact that the instant raceconscious hiring policy "does not require the selection of unqualified blacks or women over qualified white males").

191. For courts finding that waiver provisions render an affirmative action plan sufficiently "fiexible," see Donaghy v. City of Omaha, 933 F.2d 1448, 1461 (8th Cir. 1991) (finding that "[a]lthough the plan set a long-term goal, that goal could be waived because it was "subject to the availability of qualified applicants.' The plan did not require the City either to hire the unqualified or to hire unnecessary personnel . . . to meet the ... goals"); Hiller v. County of Suffolk, 977 F. Supp. 202, 207 (E.D.N.Y. 1997) (noting that a test passage waiver provision would satisfy fiexibility requireinents, but finding the program unconstitutional on other grounds); Shuford v. Ala. State Bd. of Educ., $846 \mathrm{~F}$. Supp. 1511, 1529-30 (M.D. Ala. 1994) (finding that "the goals never require the defendants to lire an unqualified African-American ... the decree allows for modification of the goals if ... the defendants made a good faith effort... and the goals are not 'reasonably attamable"'). For cases finding insufficient waiver provisions, see Freeman, 971 F. Supp. at 976 (finding that the "quotas imposed are rigid and there is no explanation provided for the percentages they mandate"); N. State Law Enforcement Officers Ass'n v. Charlotte-Mecklenburg Police Dep't, 862 F. Supp. 1445, 1459 (W.D.N.C. 1994) (finding that while a race-based hiring plan allows its terms to be modified, modification is mucl more rigid than a waiver provision; consequently, the plan's "twenty percent racial quotas are unbending, unforgiving, and sledgehammer hard").

192. See Middleton v. City of Flint, Michigan, 92 F.3d 396, 411 (6th Cir. 1996) (finding that while the Flint plan "pay[s] lip service" to the need for waivers, empirical practice shows that "these words are inerely conclusory assertions"); Ensley Branch, NAACP v. Seibels, 31 F.3d 1548, 1576 (11th Cir. 1994) (finding that 'the annual [minority] appointment 'goals' have been applied as rigid quotas.... The City apparently... believed that if it did not promote blacks and whites in approximately equal numbers, then it could make no appointments at all. As implemented, these goals lack the fiexibility that the Constitution requires."). 
are limited to single sets of hiring or promotions, courts typically find the requirement of reasonable duration satisfied. ${ }^{193}$ Furthermore, when affirmative action programs are limited to specific periods of time, courts have generally found them acceptable when that term reasonably comports with perceived need. ${ }^{194}$ When employers use race-conscious programs for undefined interim periods, however, courts more closely examine whether the discriminatory harm warrants such an extended remedy. While such programs are sometimes allowed when there are assurances that the program is both commensurate to need and periodically reviewed, ${ }^{195}$ more

193. See Howard, 871 F.2d at 1009 (finding reasonable duration when "the relief... evaporates when the 240 promotions are made"); Sims II, 887 F. Supp. at 1488 (finding reasonable duration where the "promotion of two blacks and two whites ... is a one-time measure"); Sims I, 873 F. Supp. at 605 (finding reasonable duration when the "promotion of the three blacks was a one-time interim measure used only until validated testing procedures could be put in place"); Houston Chapter of the Int'l Ass'n of Black Profl Firefighters v. City of Houston, 1991 WL 340296, at $\$ 31$ (S.D. Tex. May 3, 1991) (finding a one-time race-conscious promotions action, coupled with a six-year limit on the remediation of persisting adverse racial impact, to be of reasonable duration).

194. See Edwards, 37 F.3d at 1113-14 (upholding a remedial, race-conscious promotions scheme that stretched over ten years because such a time period minimized police department disruption and ensured that racially biased exam questions would be eliminated to the benefit of all races). But see Black Fire Fighters Ass'n of Dallas v. City of Dallas, 805 F. Supp. 426, 430 (N.D. Tex. 1992) (finding that "[a]lthough the skip promotions are proposed to be made in a short period of time, the ... effects will be felt for years to come"), aff'd, 19 F.3d 992 (5th Cir. 1994).

195. See Peightal v. Metro. Dade County (Peightal II), 26 F.3d 1545, 1559 (11th Cir. 1994); Peightal v. Metro. Dade County (Peightal I), 940 F.2d 1394, 1408 (11th Cir. 1991) (finding (in both) the duration of an interim race-conscious hiring program to be reasonable because it was tied to the accomplishment of a particular remedial goal and because there was annual review). 
often, courts will invalidate the remedy altogether, ${ }^{196}$ modify the program's duration, ${ }^{197}$ or remand the case for reevaluation on the duration issue. ${ }^{198}$

\section{The Relationship of the Numerical Goals to the Relevant Labor Market}

Much of the federal courts' discussion about the relationship of numerical goals to the relevant labor market turns on the notions of undermclusiveness and over-inclusiveness. The former describes remedies that fail to target all those affected by discrimination; the latter describes remedies that target more than those so affected. An illustration of these problems can be found im the previously discussed Peightal cases. ${ }^{199}$ There, Alan Peightal challenged a race-conscious firefighter hiring program that, among other things, gave preference to "Hispanics." Mr. Peightal alleged that this term rendered the affirmative action program both over-and underinclusive. ${ }^{200}$ On the one hand, he claimed that the referent "encompasses the same variety of ethric and racial characteristics as are found in the generalized classification of all English speaking nations; for example, it includes persons who can trace their ancestry to Spain, irrespective of

196. See Middleton, 92 F.3d at 411 (finding that a remedial plan in place for nine years, with no immediate end in sight, fails the reasonable duration requirement); Hayes v. N. State Law Enforcenent Officers Ass'n, 10 F.3d 207, 217 (4th Cir. 1993) (finding that since "[t]he City has offered no evidence regarding the duration of its use of racial preferences" and since there is "no evidence indicating that the City regularly reevaluates its use of racial preferences to insure that such preferences continue to be justified by some compelling state interest," "the City's efforts suffer from the same fatal defect ... [that] they have "no logical stopping point") (quoting Wygant v. Jackson Bd. of Educ., 476 U.S. 267, 275 (1986)); Detroit Police Officers Ass'n v. Young, 989 F.2d 225, 228 (6th Cir. 1993) (invalidating an affirmative action plan that had been in effect for nineteen years, whose renedial goal was "virtually attained," and which "has worked substantial hardship upon plaintiffs, and will continue to work severe hardship if continued any longer'); Ashton v. City of Memphis, 49 F. Supp. 2d 1051, 1067 (W.D. Tenn. 1999) (finding that an ongoing fourteen-year consent decree, with no end in sight given the continued persistence of disparity, was illegitimate given that the City sliould have already been able to develop a validated promotions test); Hiller, 977 F. Supp. at 207 (finding that the "continuation of the Cadet Program until the goals of racial balance are achieved would constitute an unreasonable duration of at least nine years"); Kane v. Freeman, 1997 U.S. Dist. LEXIS 4063, at *2223 (M.D. Fla. Mar. 17, 1997) (finding that "[l]imiting the duration of a race-conscious remedy ... is a keystone of a narrowly tailored plan" and that since the Tampa Police Department's promotion plan "is perpetual," it fails this "keystone"); Dozier v. Chupka, 763 F. Supp. 1430, 1444 (S.D. Ohio 1991) (finding that since the $19.4 \%$ minority representation "quota was established as a temporary measure to assure minority representation for the period during which the City was developing selection criteria, recruitunent programs, and validation studies in an effort to remedy past discrimination," and since these goals have been achieved, "the quota no longer serves any meaningful function").

197. Davis v. City \& County of San Francisco, 890 F.2d 1438, 1448 (9th Cir. 1989) (modifying a seven-year race-conscious hiring program to end in "seven years or sooner upon the accomplishment of the objectives or the goals of the consent decree").

198. Aiken v. City of Memphis, 37 F.3d 1155, 1164 (6th Cir. 1994) (remanding the case, in part, because "the City has made no effort to limit the duration" of race-based promotional remedies); Ensley Branch, NAACP v. Seibels, 31 F.3d 1548, 1577 (11 th Cir. 1994) (requiring that "[o]n remand, the district court must re-write the decrees to make clear that the annual goals cannot last indefinitely").

199. Peightal I, 940 F.2d at 1394; Peightal II, 26 F.3d at 1545.

200. Peightal II, 26 F.3d at 1559. 
language or culture." ${ }^{201}$ On the other hand, he claimed that while the raceconscious plan benefits those of Spanish origin, it excludes from benefit many other European races that had also suffered discrimination (for example, "Brazilians of Portuguese descent, Greeks, Jews, Italians, and Iramans"). ${ }^{202}$ Although both Peightal courts ultimately rejected these arguments, ${ }^{203}$ these opinions highlight the concern that there be a "tight fit" between the discrimination on record and the sort of remedial action imposed.

Generally, courts use a two-step process to ensure that such a fit satisfactorily exists in the remedial affirmative action program. As a threshold matter, courts tend to insist that there be a statistical assessment of the relevant labor market, for it is this benchmark that allows discrimination (and, in turn, the necessity of remedial action) to be measured. When the record is devoid of such an assessment, courts typically reject the contested raceconscious remedy. ${ }^{204} \mathrm{Next}$, courts compare the scope of remedial action to the evidenced disparity by examining the employer's minority ranks vis-àvis the relevant labor pool. By and large, courts have been much more attentive to the problem of over-mclusion than under-inclusion. While

201. Id.

202. Id. at 1561 .

203. Peightal I, 940 F.2d at 1408-10 (concluding that the plan was not overinclusive because it required a "strong visible indication that the person culturally and linguistically identifies with the group he or she claims," and rejecting the under-inclusive argument because einployers are allowed to focus their remedial prograins on groups most in need, and do not have to include all discriminatedagainst groups); Peightal II, 26 F.3d at 1558-61 (clarifying that the EEOC definition of "Hispanic" used by the County was not over-inclusive, and noting that Peightal was unable to find a single case where the definition was applied to grant relief to a non-minority).

204. See Middleton v. City of Flint, Michigan, 92 F.3d 396, 412 (6th Cir. 1996) (finding that "the record does not reflect any relationship between the numerical goal of $41.5 \%$ and the relevant labor market. ... [T] analysis that does not justify the constitutional violation here."); Long v. City of Saginaw, 911 F.2d 1192, 1202 (6th Cir. 1990) (refusing to accept disparity evidence because there was no statistical documentation of the appropriate labor pool); Ashton v. City of Memphis, 49 F. Supp. 2d 1051, 1068, 1074 n.31 (W.D. Tenn. 1999) (highlighting that since "neither party offered evidence probative on the percentage of blacks in the relevant labor force, ... it was impossible to determime whether it was necessary to use affirmative action"); Freeman v. City of Fayetteville, 971 F. Supp. 971, 976 (E.D.N.C. 1997) (finding that "[t]here are no facts in the judgment which tie the selected percentages to the racial composition of Fayetteville"); Hiller v. County of Suffolk, 977 F. Supp. 202, 207 (E.D.N.Y. 1997) (finding that "prima facie discrinuination" could not be proven when "the statistics provided may not have accurately assessed the percentage of the labor force that would satisfy the additional qualifications needed to be appointed as a Suffolk County Police Officer'); N. State Law Enforcement Officers Ass'n v. Charlotte-Mecklenburg Police Dep't, 862 F. Supp. 1445, 1459 (W.D.N.C. 1994) (finding that "[i]t is impossible to tell whether the twenty percent goals are reasonably related to the percentage of qualified blacks in the relevant labor pool because there are no factual findings that the Court even knew what those percentages were"). But see Shuford v. Ala. State Bd. of Educ. (Shuford I), 846 F. Supp. 1511, 1530-31 (M.D. Ala. 1994); Shuford v. Ala. State Bd. of Educ. (Shuford II), 897 F. Supp. 1535, 1569-70 (M.D. Ala. 1995) (finding (m both) that although a relevant labor pool could not be determined, informed estimates coupled with ongoing modification were sufficient to ensure that the contested program was narrowly tailored). 
many courts carefully consider whether the remedial goals of an affirmative action plan overshoot the apparent disparity, ${ }^{205}$ very few explicitly consider whether a remedial plan undercompensates groups that have historically suffered discrimination at the employer's hands. ${ }^{206}$

Though there are a number of issues running through these cases, two warrant special inention. The first involves a definitional dispute over exactly how the "relevant" labor pool should be defined in the hiring and promotion contexts. Previously, we saw that this dispute raises such concerns as the relevance of considering applicants in the race-conscious hiring process, and the efficacy of looking beyond lower-rank minority representation in the race-conscious promotion process. ${ }^{207}$ These issues reeinerge because of a tension in the Supreme Court's jurisprudence: On the one hand, the Court cautions against the "'completely unrealistic' assumption that minorities will choose a particular trade in lockstep

205. Some courts have found workplace affirmative action plans narrowly tailored in the face of over-inclusion challenges. See Boston Police Superior Officers Ass'n v. City of Boston, 147 F.3d 13, 24 (Ist Cir. 1998) (finding the race-conscious promotion of one African-American to he "no greater than necessary to reinedy the [Boston Police Department's] past discrimination"); Edwards v. City of Houston, 37 F.3d 1097, 1114 (5th Cir. 1994) (finding that "[t]he number of remedial promotions exactly matches the number of promotions lost by black and hispanic [sic] police officers [on account of discrimination]."); Donaghy v. City of Omaha, 933 F.2d 1448, 1461 (8th Cir. 1991) (finding that "the interim promotion goal was directly tied to the relevant work force, nanrely the percentage of quahified blacks eligible for promotion within the [Omaha Police Department]"); Paganucci v. City of New York, 785 F. Supp. 467, 478 (S.D.N.Y. 1992) (finding that "[t]he only beneficiaries of the settlement are the minority officers who were affected by the examination's disparate impact, and thus the settlement is not overinclusive"), aff'd, 993 F.2d 310 (2d Cir. 1993). Other courts have invalidated workplace affirmative action plans for being overinclusive. See In re Birminghan Reverse Discrimination Employment Litig., 20 F.3d 1525, 1549 (11th Cir. 1994) (holding that "the City's affirmative action plan does not use race in a narrowly tailored manner" because "there is no relationship between the numerical goal for fire lieutenant promotions and the representation of blacks among firefighters"); Koski v. Gainer, 1995 WL 599052, at *16 (N.D. Ill. Oct. 5, 1995) (finding remedial goals overinclusive in that they exceeded the "sappropriate work force' ... against which to measure its past discrimination"); Black Fire Fighters Ass'n of Dallas v. City of Dallas, 805 F. Supp. 426, 430 (N.D. Tex. 1992) (finding that the number of skip proinotions mandated by a proposed settleinent agreeinent are overbroad hecause "the actual shortfall in African American promotions is not nearly as high as plaintiffs urge"), aff'd, 19 F.3d 992 (5th Cir. 1994). See also Aiken v. City of Meinphis, 37 F.3d 1155, 1164 (6th Cir. 1994) (remanding the case to the district court because "the proinotion goals set forth in the... decrees may not bear a sufficiently precise relationship to the 'relevant labor market' to be 'narrowly tailored"').

206. While under-inclusion was addressed in the Peightal cases, see supra notes 199-203 and accoinpanying text, the occasional case also makes reference to the under-inclusion problem without probing it thoroughly. See Sims v. Montgoinery County Comin'n (Sims II), 887 F. Supp. 1479, 1488 (M.D. Ala. 1995) (finding that "the four proposed promotions are neither over-inclusive nor under-mclusive.... [they] apply only to those who were qualified for promotion within the department"); Sims v. Montgoinery County Comm'n (Sims I), 873 F. Supp. 585, 606 (M.D. Ala. 1994) (finding that "[t]he 1988 promotions were neither over-inclusive nor under-inclusive... [since they] applied only to those who were qualified for promotion within the department"). This focus on overinclusion, however, should not be terribly surprising since the far majority of these workplace affirmative action plans are pursued voluntarily; it stands to reason that courts would be more concerned with these plans going too far, rather than not far enough.

207. Supra Part II.B.3. 
proportion to their representation in the local population",;08 on the other hand, the Court expects this same local population to be the benchmark for determining appropriately tailored remedial goals. ${ }^{209}$ In Part II, I showed how some courts look to the number of minority applicants, rather than aggregate minority representation im a population, to determine the "relevant" labor pool for race-conscious hiring plans. ${ }^{210}$ Similarly, I showed that some courts are conflicted when defining the "relevant" pool for race-conscious proniotion plans. ${ }^{211}$ Not surprisingly, courts rehash these same issues in the context of narrow tailoring. ${ }^{212}$

Second, I have shown that courts sometimes allow purposely "over-inclusive" numerical goals (on a temporary basis) to accelerate relief. In Paradise for example, the Court permitted the use of a fifty percent race-conscious hiring floor so as to reach the goal of twenty-five percent black representation on the police force more quickly. ${ }^{213}$ Lower federal courts have responded to this remedial option $\mathrm{m}$ a number of ways. Some courts have explicitly followed Paradise's lead, approving numerical remedial goals that exceed documented statistical disparity. ${ }^{214}$ Other courts have either distinguished Paradise, finding such "over-mclusion" permissible only $\dot{n} 1$ very limited circumstances, ${ }^{215}$ or have implicitly

\footnotetext{
208. Supra note 176 and accompanying text.

209. Supra note 100 and accompanying text.

210. Supra Part II.B.3.

211. Id.
}

212. For an example in the hiring context, see Ashton v. City of Memphis, 49 F. Supp. 2d 1051, 1069,1069 n.23 (W.D. Tenn. 1999) (finding that the "relevant labor market should be defined as the number of applicants who were actually qualified for the job," and as such, "[a] study that entirely fails to account for a given race's propensity to apply for a specific job .... is legally deficient'). For examples in the promotions context, see Aiken v. City of Memphis, 37 F.3d 1155, 1165 (6th Cir. 1994) (finding that because the "promotion goals are tied to the hiring goals," and the "hiring goals are determined by reference to... undifferentiated" statistics, "the promotion goals ultimately are tied to undifferentiated ... statistics" as well); Edwards v. City of Houston, 37 F.3d 1097, 1114 n.13 (5th Cir. 1994) (refusing to "reach the issue of whether the number of minorities who took the [promotion] exam is the only relevant labor market"); Dallas Fire Fighters Association v. City of Dallas, Texas, $885 \mathrm{~F}$. Supp. 915,923 (N.D. Tex. 1995) (finding that the "promotional goals should be statistically related to the number of qualified applicants in each rank below").

213. United States v. Paradise, 480 U.S. 149, 179, 182 (1987).

214. See Aiken, 37 F.3d at 1164-65 (finding it pernissible to use infiated numerical goals as "a means of speedily realizing the long-term goais of the decrees"); Ensley Branch, NAACP v. Seibels, 31 F.3d 1548, 1577 (1 1 th Cir. 1994) (holding that "[t]he district court may set an annual affirmative action goal that is greater than the proportion of blacks in the qualified labor pool... [when discrimination] has reduced the proportion of blacks either in the qualified pool or in the position itself'); Howard v. McLucas, 871 F.2d 1000, 1008 (11th Cir. 1989) (allowing a fiexible 50\% numerical remedy to "expeditious[ly]" identify patterns of racial exclusion in hiring). For an example of this "Paradise principle" outside the workplace context, see Cone Corp. v. Hillsborough County, 908 F.2d 908 (11th Cir. 1990) (approving a numerical goal in the contracting set-aside context that was approximately twice the proportion of minorities in the qualified labor pool).

215. See Middleton v. City of Flint, Michigan, 92 F.3d 396, 412 (6th Cir. 1996) (finding that only "[i]n a situation such as Paradise, where the exclusion had been total ... was [it] far more plausible to enforce a draconian remedy, as the information necessary to any type of narrow tailoring was absent"). 
rejected the Paradise approach, requiring instead a tight fit between the evidenced disparity and the race-conscious remedial goal. ${ }^{216}$

\section{The Impact of Relief on the Rights of Third Parties}

The fourth factor of the Paradise analysis, the impact of relief on the rights of third parties, does not play a pronounced role in most workplace affirmative action cases. The overwhelming majority of race-conscious hiring and promotion plans considered by federal courts are judged to have only a nominal impact on the rights of third parties. ${ }^{217}$ On the rare occasions when courts use this factor to invalidate an employer's affirmative action plan, they do so in one of two ways. Some courts have found that certain race-conscious promotion plans place too large a burden on non-minority workers. ${ }^{218}$ Other courts have found that race-conscious firing is uniquely burdensome to third parties and that this type of affirmative action is much more susceptible to mvalidation than hiring or promotion schemes. ${ }^{219}$

216. See In re Birmingham Reverse Discrimination Employment Litig., 20 F.3d 1525, 1543 (11th Cir. 1994) (finding that a $50 \%$ "quota" could not be used to reach the numerical goal of $28 \%$ AfricanAmerican representation).

217. Many cases find no substantial harm to third party rights in the hiring context. See Peightal v. Metro. Dade County (Peightal II), 26 F.3d 1545,1561 (11th Cir. 1994); Jansen v. City of Cincinnati, 977 F.2d 238, 244 (6th Cir. 1992); Vogel v. City of Cincinnati, 959 F.2d 594, 599 (6th Cir. 1992); Peightal v. Metro. Dade County (Peightal N), 940 F.2d 1394, 1410 (11th Cir. 1991). Other such cases can be found in the promotion context. See Boston Police Superior Officers Ass'n v. City of Boston, 147 F.3d 13, 24 (1st Cir. 1998); Edwards, 37 F.3d at 1114; Howard, 871 F.2d at 1009-10; Sims v. Montgomery County Comm'n (Sims II), 887 F. Supp. 1479, 1488 (M.D. Ala. 1995); Sims v. Montgoinery County Comm'n (Sims I), 873 F. Supp. 585, 606 (M.D. Ala. 1994); Houston Chapter of the Int'l Ass'n of Black Prof'1 Firefighters v. City of Houston, 1991 WL 340296, at $₹ 33$ (S.D. Tex. May 3, 1991). Fimally, there are a number of decisions that find no substantial impact on third parties from such race-conscious efforts as minority recruiting, altering promotion qualifications, and test validation. See Allen v. Ala. State Bd. of Educ., 976 F. Supp. 1410, 1431 (M.D. Ala. 1997), affd, 164 F.3d 1347 (11th Cir. 1999); Shuford v. Ala. State Bd. of Educ., 846 F. Supp. 1511, 1531-32 (M.D. Ala. 1994).

218. Most courts that come to this conclusion, however, fail to articulate clear standards regarding exactly where the burden becomes too great. See Middleton, 92 F.3d at 413 (finding that denying "eligible white candidates their eamed opportunity to be promoted ... constitute[s] a very significant, and legally cognizable, adverse impact on the rights of third parties"); Ashton v. City of Memphis, 49 F. Supp. 2d 1051, 1074 (W.D. Teun. 1999) (finding that while the burdens imposed by race-conscious promotious "may not have been large, that burden was placed on a very focused group of individuals"); Kane v. Freeman, 1997 U.S. Dist. LEXIS 4063, at *27 (M.D. Fla. Mar. 17, 1997) (finding that “" [s]kip" promotions disrupt the settled expectations and rights of each candidate passed over in favor of a less qualified candidate"); Dallas Fire Fighters Ass'n v. City of Dallas, Texas, 885 F. Supp. 915, 923 (N.D. Tex. 1995) (finding that "[t] he policy of ranking scores on validated tests creates an expectation in all firefighters that promotions can be earned by studying for the test," and thus, "[t] undermime this expectation with skip promotions that are not narrowly tailored").

219. See, e.g., Crumpton v. Bridgeport Educ. Ass'n, 993 F.2d 1023, 1031 (2nd Cir. 1993) (observing that "[n]o court ... has held that a layoff procedure giving absolute preference to minorities is narrowly tailored" while invalidating a race-conscious firing plan); Cunico v. Pueblo Sch. Dist. No. 60, 917 F.2d 431, 440 (10th Cir. 1990) (invalidating a race-conscious layoff decision while expressing doubt that "race-conscious layoffs, as opposed to hiring goals, can ever be deemed a narrow means of 
This review of narrow tailoring doctrine reveals similar lessons as those that emerged from the "strong basis in evidence" inquiry. Once again, there is evidence of substantial doctrinal ambiguity. On the question of race-neutral alternatives, it is unclear whether an employer must have already tried such alternatives, whether the employer must provide evidence of the inadequacy of all possible prospective alternatives, or both. Regarding flexibility, it is unclear how employers should navigate the line between using numerical goals keyed to the "relevant" labor pool and avoiding the perception of pursuing "racial parity." And on the question of over-inclusion, it is unclear how aggressive employers can be when devising numerical goals that exceed remedial need so as to accelerate relief. In sum, there are substantial gaps in the narrow tailoring analysis prescribed by the Supreme Court, gaps that leave lower federal courts considerable leeway when evaluating the constitutionality of workplace affirmative action plans.

The federal courts' narrow tailoring analysis also further undermines the dominant narrative. Many courts have aggressively protected affirmative action plans that operate in the interstices of Supreme Court doctrine: some have permitted race-conscious hiring and promotion plans with only a nominal showing of attempted race-neutral alternatives; some have facilitated skip-promotion plans by allowing employers to experiment with such strategies as banding, strategies whose logic could easily be extended into the education context; ${ }^{220}$ and some have approved efforts by employers to accelerate remediation by adopting minority representation goals that far exceed statistical disparity. Furtherinore, it is telling that courts have by and large de-emphasized concerns about the impact of affirmative action plans on third parties. So long as the plan does not entail race-conscious firing, courts have overwhelmingly rejected the notion that the constitutionality of affirmative action should turn on the frustrations of disgruntled workers passed over in the hiring and promotion contexts. These developments reveal that while courts have carefully scrutinized the use of racial classifications in the employment context, demandmg a tight fit between the remedial goals and the evidenced disparity, this scrutiny has been far from fatal and has permitted a wide spectrum of race-conscious remedies.

Finally, this analysis again cautions against pressing the hiberal "counter-narrative" too far. While courts have gone to the left at the first sign of doctrinal ambiguity, so too have some gone to the right. At times, unabashed hostility toward race-conscious decision making is discernible: some courts have pushed the necessity of considering alternatives,

accomplishing an otherwise legitimate remedial purpose'). This concern stems from the Court's holding in Wygant. See Part II.A.1.

220. For a discussion of this logic's relevance to affirmative action in the educational arena, see infra note 239 and accompanying text. 
both historically and prospectively, to the point of making it nearly impossible to consider race when making hiring and promotion decisions; some courts characterize affirmative action programs as seeking "racial parity" when the employer is doing hittle more than adopting as a goal minority representation rates in the "relevant" labor pool; and some courts have focused on avoiding over-inclusion to the point of ruling out remedial acceleration. While it would be incorrect to portray large sections of federal jurisprudence as hostile toward benign racial classifications, enough such hostility is present to take notice.

\section{IV \\ REVISITING THE DOMINANT NARRATIVE}

I conclude by briefly sketching the harm engendered by the dominant narrative, the promise that lies im a more nuanced popular understanding of affirmative action, and the role that this Comment might play im the formulation of such an understanding.

Failure to question adequately the pervading "wisdom" of affirmative action has directly undermined the continued political viability of raceconscious decision making. It is ironic that just as we have begun to see firm evidence of affirmative action's success in opening this nation's schools and businesses to minorities, ${ }^{221}$ affirmative action itself has become something of a political pariah. A recent poll, for example, revealed that a full flfty percent of this nation's college students beheve that affirmative action should be wholly abolished. At the same time, however, seventy percent of these students support admissions officers giving "special consideration" to race. ${ }^{222}$ When people are asked either to explain why they so disfavor affirmative action, or to explain how "affirmative action"

221. For a sampling of data on the historic success of affirmative action, and of its continuing inportance, see William G. Bowen \& Derek Bok, THE SHAPE OF THE Rrver: LONG-TERM Consequences of Considering Race IN College and University Admissions (1998); Bruno, supra note 2, at 85-95; Linda F. Wightman, The Threat to Diversity in Legal Education: An Empirical Analysis of the Consequences of Abandoning Race as a Factor in Law School Admission Decisions, 72 N.Y.U. L. REv. 1, 3 (1997); ACLU, Reaching for the Dream: Profiles in Affirmative Action (1998), at http://www.aclu-sc.org/dream.htm (last visited Sept. 29, 2000); Opportunities Lost: The State of Public Sector Affirmative Action in Post Proposition 209 California (1998) at http://www.equalrights.org/ survproj/index.htm (last visited Sept. 29, 2000) (a joint project of Chinese for Affirmative Action and Equal Rights Advccates). There is, however, a lively debate regarding the empirical benefits of affirmative action. E.g., Michael K. Braswell, et al, Affirmative Action: An Assessment of its Continuing Role in Employment Discrimination Policy, 57 ALB. L. REv. 365, 439 (1993) ("Affirmative action, which primarily addresses discrimination in the workplace, is sinply not an effective means to deal with these problems, as they affect the prospects of these individuals before they even enter the labor force." Brawell continued: "In fact, continuing einphasis on affirmative action as a means of achieving equal einployment opportunity detracts froin measures that might be more effective and appropriate to addressing these disparities and to help those disadvantaged individuals who need it inost.").

222. Tamara Henry, Freshmen Back Admissions for Race, Not Affirmative Action, USA TODAY, Jan. 8, 1996, at 1A. 
differs from "special" racial considerations, an extremely distorted picture emerges: questioned individuals reply that affirmative action both benefits many who have no proximate tie to historical discrimination, and exacts tremendous hardship upon innocent non-minorities. ${ }^{223}$ Findings such as these reveal a citizenry in the throws of symbolic confusion; there is little understanding of what "affirmative action" means, and consequently, the term has become a lightening rod for manipulation. ${ }^{224}$

Amidst this politically charged and semantically confused environment, the dominant narrative has become fodder for political machination; as more commentators fallaciously describe the judiciary's "end of affirmative action," narrative structures both construct affirmative action as being constitutionally untenable and allow opponents of affirmative action to draw upon this unconstitutional ethos. One need only look to how the California's "Civil Rights Initiative" symbolically aligned itself with the federal courts' supposed "opposition" to race-conscious decision making to apprehend the stark discursive link between the narrative being told about affirmative action in the courts and larger societal narratives of color-blindness. Given the force of legal narratives, the stories that we tell about the courts have significant cultural impact: "Widespread acceptance of prevailing legal norms is more likely to reflect a consciousness of their inevitability and practical necessity rather than of their intrinsic justice."225 As people are told over and over again that federal courts have given up on affirmative action, they too might give up. ${ }^{226}$

223. E.g., Jack Citrin, Affirmative Action in the People's Court, 1996 PUB. INTEREST 39; John O. McGinnis, The Peculiar Institution, NAT'L REV., Oct. 14, 1996, at 62, 64-67.

224. For a discussion of how racial issues generally, and affirmative action specifically, are manipulated in American politics, see Michael Goldfield, The Color of Polimics: Race, Class, and The Mainsprings of American Polmics (1997). See also Linda Faye Williams, Tracing the Politics of Affirmative Action, in The Affirmative Action Debate 241, 241-57 (George E. Curry ed., 1996).

225. Michael W. McCann, Rights at Work 305-06 (1994).

226. E.g., John Gaventa, Power and Powerlessness (1980). According to Gaventa, as people perceive that legal structures are against a particular social position, these perceptions becoine routinized and a sense of "powerless[ness]" ensues. While Gaventa's argument differs from the more general notion that appeals to the federal judiciary's authority have unique persuasive force, this sociological explanation further demonstrates the dominant narrative's deleterious effect on affirmative action. Professor Kimberle Crenshaw reveals that this concern of "powerlessness" is not an abstract academic concern; rather it is precisely what has occurred in the affirmative action context:

From the anti-affirmative action initiatives in Washington and California to the Hopwood decision in Texas and the pending suit against the University of Michigan, the message is clear that the corpus of affirmative action policies is in crisis. Those of us who support affirmative action seem to be stricken by a certain paralysis precluding us from effectively defending these policies. Fear that the outcome is somehow inevitable seems widespread; most seem to believe that it's only a matter of time before the plug is pulled and affirmative action as we know it will cxist no more. This sense of inevitability has sapped the creativity and energy of allies in the institutions most immediately damaged in the affirmative action wars in California, in Texas, and no doubt in Washington as well.

Crenshaw, supra note 36, at 197. 
Given this dominant narrative's seeming ubiquity, efforts should be taken to retell the contemporary story of affirmative action and to paint a more accurate picture of racially conscious programs emerging from today's federal courts. Professor Kimberle Crenshaw recently observed: "Our task now is in figuring out ways of consolidating progressive support for affirmative action, reaching out and persuading our liberal and centrist allies about the continuing need for affirmative action and finding the best ways to defend it."227 One such way to mount a better defense of affirmative action is to resist the dominant narrative, to bring the reasoning of those pro-affirmative action federal decisions into the public light, and to show that there are many examples of affirmative action that satisfy even the strictest notions of fairness and equity. By highlighting how federal courts have validated many affirmative action plans even under the doctrinal rubric of strict scrutiny, defenders of race-conscious policies might succeed in reclaiming some of the persuasive ethos that comes with the federal judiciary's constitutional imprimatur.

One might question, however, whether this Cominent's focus on public employment, and the lessons drawn from that doctrinal area, in fact call into question larger stories being told about affirmative action in the educational, contracting, or statewide ballot mitiative contexts. I offer three reasons for beheving that it does.

First, it is true that the various arenas of affirmative action differ, in meaningful respects, from one another and that one cannot infer jurisprudential vitality in the educational or contracting contexts simply from evidence of such vitality im the public workplace. The Bakke line of cases, for example, importantly differs from the Croson and Adarand line; while courts typically permit affirmative action in the latter cases only when there is identified remedial need, courts typically evaluate the former cases on altogether different grounds. ${ }^{228}$ That being said, the disjoint between commentator rhetoric and doctrinal reality in the employment context does suggest the need for a more rigorous and nuanced popnlar understanding of affirmative action writ large. Part 1 illustrates that commentators regularly draw generalized conclusions about the "demise of affirmative action" from particular court decisions and statewide mitiatives. To the extent that I can provoke proponents of the dominant narrative to dispute the generalizabihity of my case study, to marshal arguments that distinguish one arena of affirmative action from another, I will be satisfied, for the very logic of these distinctions would avoid treating the doctrine of affirmative action as an undifferentiated whole.

227. Crenshaw, supra note 36, at 211.

228. For an example of the type of consideration that a court might entertain in the education context, hut not in the contracting or employment context, see infra note 231 . 
Second, while the scope of this Comment precludes a systematic review of all affirmative action contexts, I submit that the vitality of raceconscious measures seen in Parts II and III is not limited to public employment. In the sphere of public contracting, federal courts have, im the past decade, upheld minority contraetor set-aside programs against equal protection challenges nearly thirty percent of the time. ${ }^{229}$ In the sphere of public education, while it is true that lower federal courts have more often than not constitutionally invalidated racially conscious school admission policies, ${ }^{230}$ federal courts have not been uniformly hostile to affirmative action ${ }^{231}$ and federal courts outside the Fifth Circuit have fastidiously avoided the extreme Hopwood position that rejects diversity per se as a compellimg state interest. ${ }^{232}$ In the sphere of statewide ballot initiatives, it is not necessarily the case that these well publicized referendums reflect uniformly hostile public attitudes toward affirmative action. Professor Kimberle Crenshaw, for example, observes "that despite predictions of an overwhelming victory for Prop. 209, it passed by only a smgle digit margin."233 Professor Crenshaw further attributes part of the

229. Supra note 25 .

230. E.g., Tuttle v. Arlington County Sch. Bd., 195 F.3d 698 (4th Cir. 1999) (finding that a proposed school board adinissions policy designed to promote racial, ethnic, and socioeconomic diversity was not narrowly tailored to promote the interest of diversity); Wessmann v. Gittens, 160 F.3d 790 (1st Cir. 1998) (finding that the Boston Latin School's racially and ethnically conscious admissions policy was justified neither on the asserted governmental interest of diversity nor remediation).

231. E.g., Hunter v. Regents of Univ. of Cal., 190 F.3d 1061 (9th Cir. 1999) (finding that a state's interest in the operation of a research-oriented elementary school dedicated to improving urban public schools was a compelling state interest that justified the use of racially-conscious admissions policy). The Hunter case is perhaps most interesting because of its rhetorically powerful account of the role of urban schools in American democracy:

"Education is perhaps the most important function of state and local governments." The Supreme Court has recognized "the public schools as a most vital civic institution for the preservation of a democratic system of government."'

..." $[t]$ here is no more pressing problem facing Califomia, or indeed the nation, than urban education; for it is $m$ the urban school system that the majority of California's future citizens will be educated (either well or poorly), crcating the basic fabric for the society of the future."

Id. at 1063-64 (citations omitted). While 1 would make the dominant narrative's synecdochic error if I suggested that this decision holds broad precedential value, it is noteworthy that the theory underlying Hunter, the promotion of a democratic public culture, is one that has been suggested by commentators as a way of escaping notions of group entitlement that heretofore have dominated the thetoric of affirmative action. See Post, supra note 12, at 24 ("[T]he university's obligation to encourage a flourishing public culture may well require standards of admission that explicitly recognize rac[e] ... [not because of] any theory of group rights or entitlements ... [but because of] the educational goal of fostering the public culture on which rests the success of democratic self-govemance.").

232. E.g., Tuttle, 195 F.3d at 705 (finding that "nothing in Bakke or subsequent Supreme Court decisions clearly forecloses the possibility that diversity may be a compelling interest" and that "[u]ntil the Supreme Court provides decisive guidance, we will assune, without so holding, that diversity may be a compelling governmental interest"); Wessmann, 160 F.3d at 796 (finding that while Hopwood may be correct $i m$ that the Supreme Court today would not find diversity to be a compelling state interest, "[i]t has not done so yet... and we are not prepared to make such a declaration in the absence of a clear signal that we should").

233. Crenshaw, supra note 36, at 203. 
initiative's success to the fact that voters were "tricked" by the Proposition's deceptive wording; it seems that many who voted for Proposition 209 did not recognize that its practical effect was the elimination of affirmative action. ${ }^{234}$ While these characterizations of affirmative action in the contracting, education, and statewide initiative contexts are of course contestable, and more complicated than this short paragraph could possibly acknowledge, I highlight them to illustrate that the conclusions I draw from the public employment context have some applicability to the other arenas of affirmative action.

Third, even if one were convinced that as an empirical matter the conclusions drawn in Parts II and III are not generalizable to other affirmative action contexts, this Comment's case study should enable advocates of affirmative action to better defend the race-conscious project. I conclude by mentioning two possibilities. Initially, it is iromic that while the federal judiciary routinely finds affirmative action plans to exact only a minor, diffused effect on passed-over white employees, ${ }^{235}$ there is widespread public perception that affirmative action programs disproportionately place sizeable demands on whites. ${ }^{236}$ Advocates of race-conscious decision making should invoke the federal courts' findings of nommal third party impact, and the legal authority behind them, to address this public inisperception. Additionally, the successful use of "banding" in the public employment context, where public employers making hiring and promotion decisions look not to strict rank ordering of applicable test scores but rather to groups of individuals that fall within a similar range of scores, ${ }^{237}$ offers a productive and under-explored avenue for defending affirmative action in the educational arena. The justification for banding in the workplace turns on the relatively imprecise predictive force of tests as tools for measuring job performance. ${ }^{238}$ While the federal judiciary has not, to the best of iny knowledge, considered the logic of banding in the education context, at least one commentator has observed that a banding-type argument could have powerful persuasive force as proponents of affirmative action seek to expand popular support for racially-conscious admissions policies. ${ }^{239}$

234. Id. at 204 n.23. In support of this point, Professor Crenshaw points to the defeat of an antiaffirmative action initiative in Houston, Texas, a defeat that "has been attributed to the fact that opponents of the measure managed to re-word the proposal" to make it clear that the very fate of affirmative action was at stake. Id. at $204 \&$ n.24. The impact of these semantic differences leads Professor Crenshaw to observe that "opposition to affirmative action is not the juggernaut that critics often invoke." Id, at 203.

235. See Part III.B.4.

236. Bruno, supra note 2 , at 84 .

237. For examples of cases where banding was permitted in the public employment context, see Jansen v. City of Cincinnati, 977 F.2d 238, 243 (6th Cir. 1992); Officers for Justice v. Civil Service Commission, 979 F.2d 721, 727 (9th Cir. 1992).

238. For illustrations of this judicial reasoning, see the parenthetical quotations of Jansen and Officers for Justice, supra note 190.

239. Professor Kimberle Crenshaw comments on the promise of this argument: 


\section{CONCLUSION}

Modern affirmative action jurisprudence is more conflicted than commentators generally acknowledge; while some courts have consistently upheld aggressive affirmative action programs, others have rolled back affirmative action further than the Supreme Court's doctrine seemingly warrants. Amidst this confusion, too many comunentators write off affirmative action as if the federal judiciary has soundly rejected the raceconscious project, thus obfuscating both the continued vitality of affirmative action and the unresolved doctrinal issues in the Court's race-based jurisprudence. Such inaccurate comunentary, however, only exacerbates the confusion. As Professor Howard Zinn observes: "[T] he campaign against affirmative action has to some extent been successful only because the facts have not been presented, the arguments have not been clearly made. Over the long run, the truths should prevail, and Americans will accept them, out of a natural desire for fairness."240 Professor Zinn's optimism is bolstered by the fact that public opinion is not uniformly critical of affirmative action. While the public tends to disapprove of race-conscious decision making when framed in terms of strict racial quotas, ${ }^{241}$ substantial support can be found for programs that both aggressively recruit and train minority applicants ${ }^{242}$ and endeavor to remedy identified instances of

We should also target our strategy to reach the many Americans sincerely concerned with effectuating equality but who remain ambivalent about affirmative action because they view it as constituting some sort of departure from merit. Here we must play our trump regarding tests, specifically, that test scores and other criteria used to measure merit have not been shown to be predictive of professional attainment. This fact is backed up by disclaimers issued by the testing industry itself. They have repeatedly stated that the use of standardized tests to rank candidates along the assumption that a higher score correlates with 'more qualification' is an abuse of the test. Many, if not inost institutions of higher learning misuse test scores in this way. Indeed, differences in test scores that lie within the margin of error can often make a difference in whether an applicant is adınitted or not.

Crenshaw, supra note 36, at 207.

240. Howard Zinn, Affirmative Action: A Long-Range Perspective, in RACE AND

REPRESENTATION, supra note 12, at 395.

241. See supra notes 15-16.

242. Bruno, supra note 2, at 81 (reporting a May 1991 Harris survey that found $78 \%$ support for the proposition that "[a]s long as there are no rigid quotas, it makes sense to give special training and advice to women and minorities so that they can perform better on the job"). Some might question my implicit classification of "recruitment" as a form of affirmative action. Robert Alt, for example, characterizes this imclusive definition of affirmative action as a strategically disingenuous liberal move: "[A]dvocates of preferential affirmative action often deliberately manipulate the term affirmative action, by foreing definitions of the term which suit their immediate arguments. This system of redefinition allows preferential advocates to argue . . . that affirmative action is not simply set-asides or quotas-stressing the more palatable and constitutional outreach defimition of affirmative action." Alt, supra note 47, at 182. Criticism of this sort, however, simply ignores recent judicial developments. As it turns out, courts are relatively confiicted over whether minority recruitment demands strict scrutiny. Compare Duffy v. Wolle, 123 F.3d 1026, 1038-39 (8th Cir. 1997) (finding that "[a]n einployer's affirmative efforts to recruit minority and female applicants does not constitute discrimination."); Honadle v. Univ. of Vt. \& State Agric. Coll., 56 F. Supp. 2d 419, 428 (D. Vt. 1999) 
discrimination through flexible, narrowly tailored means. ${ }^{243}$

While Professor Zinn's optimism may be well founded, the fact remains that popular perceptions of affirmative action are both distorted and precipitously eroding. What is needed is "more attention to affirmative action as it is practiced," for "only research that aims toward dispassionate analysis can provide the imtellectual space for people to separate their broad views about. American racial practices from their particular judgments about the efficacy of affirmative action as coinpared to other policy possibilities."244 The foregomg is but a small step in such a "dispassionate" direction. ${ }^{245}$ The very notion of "affirmative action" has been highly politicized; despite the federal judiciary's careful infusion of flexibility and desert into the affirmative action context, popular misconceptions abound regarding rigid quotas and undeserving recipients. By placing focus on how federal courts have msisted upon, and often upheld, prudently constructed affirmative action plans, it may be possible to popularly demonstrate that equity and remedial success are not mutually exclusive in the arena of racially-conscious preferences. While it remains to be seen whether Americans will, in fact, ultimately accept affirmative action "out of a natural desire for fairness," questioning the dominant narrative hopefully will prompt a more sophisticated popular understanding of affirmative action, an understanding that appreciates both the care demanded by the federal judiciary in the construction and implementation of racially-conscious programs and the continuing need of public employers, contractors, and educators to take race into account.

(finding that strict scrutiny was not triggered because it was "not demonstrated by a preponderance that [the minority incentive program] ha[d] the purpose of creating an inducement to hire"); and Raso v. Lago, 958 F. Supp. 686, 702 (D. Mass. 1997) (finding that "[a]lthough the affirmative recruitunent of minority applicants is race-conscious conduct... such conduct alone does not constitute a 'preference' ... because [t] be crucial distinction is between expanding the applicant pool and actually selecting from that pool"), aff'd, 135 F.3d 11 (1st Cir. 1998) (citations omitted), with Lutheran ChurchMo. Synod v. FCC, 141 F.3d 344 (D.C. Cir. 1998) (finding that FCC regulations that provided strong incentives for radio station owners to grant racial hiring preferences were subject to strict scrutiny) and Monterey Mech. Co. v. Wilson, 125 F.3d 702 (9th Cir. 1997) (finding that Cahfornia statute that encouraged active solicitation of minority business enterprises was subject to strict scrutiny). What these cases tell us is that "recruitunent" at the very least falls within the boundary of "affirmative action" broadly defined.

243. See supra note 16.

244. Jennifer Hochschild, Affirmative Action as Culture War, in Race AND REPRESENTATION, supra note 12 , at 347,351 .

245. Some might question whether this Comment in fact offers the type of "dispassionate" analysis counseled by Professor Hochschild. I cannot deny that 1 am a firm advocate of affirmative action and that 1 write this piece (in part) to tell a story of affirmative action that is more conducive to its continued viability. These motivations notwithstanding, however, the crux of this piece is to provide an objective account of what lower federal courts have done with affirmative action over the last decade; in this respect, at least, I hope to offer a "dispassionate" voice. 
